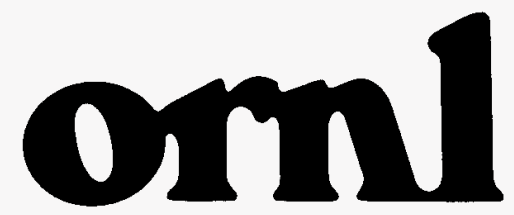

\section{OAK RIDGE} NATIONAL LABORATORY

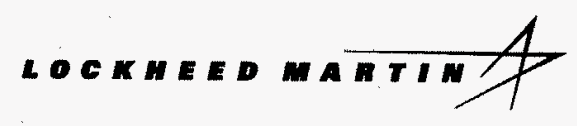

\section{IECEIVED}

\author{
JAN 231998 \\ OSTI
}

\title{
Hot Demonstration of Proposed Commercial Cesium Removal Technology: Progress Report
}

D. D. Lee

J. R. Travis

M. R. Gibson

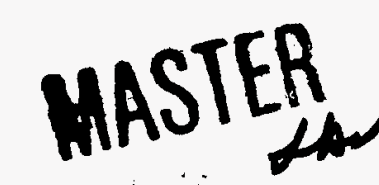

Docurient is unimite. 
This report has been reproduced directly from the best availablo copy.

Available to DOE and DOE contractors from the Otfice of Scientific and Technical information, P.O. Box 62. Oak Ridge, TN 37831; prices available from (615) 576-8-401, FTS 626-8401.

Available to the public from the National Technical Information Service, U.S. Depariment of Commerce, 5285 Port Royal Rd., Springfield, VA 22161.

This report was prepared as an account of work sponsored by an agency $n^{\prime}$ the United States Government. Neither the United States Government nor any agency thereof, nor any of their employess, makes any warranty, express or implied, or assumes any legal liability or responsibility for the accuracy, completeness, or usefulness of any intormation, epparalus, product, or process disclosed, or represents that its use would not infringe privately owned rights. Reference herein 10 any specific commercial product, process. or service by trade name. trademark, manufacturer, or otherwise, doss not necessarily constitute or imply its endorsement. recommendation, or favoring by the United States Government or any agency thereol. The views and opinions of authors expressed herein do not necessarily state or reflect those of the United States Government or any agency thereot. 


\section{Chemical Technology Division}

\section{HOT DEMONSTRATION OF PROPOSED COMMERCIAL CESIUM REMOVAL TECHNOLOGY: PROGRESS REPORT}

D. D. Lee, J. R. Travis, and M. R. Gibson

Date Published - December 1997

Prepared for the

U.S. Department of Energy Office of Science and Technology Efficient Separations and Processing Cross-Cutting Program

Prepared by the

OAK RIDGE NATIONAL LABORATORY

Oak Ridge, Tennessee 37831-6285

managed by

LOCKHEED MARTIN ENERGY RESEARCH CORP.

for the

U.S. DEPARTMENT OF ENERGY

under Contract DE-AC05-96OR22464 


\section{CONTENTS}

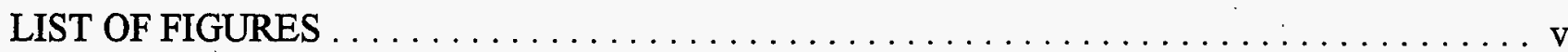

LIST OF TABLES $\ldots \ldots \ldots \ldots \ldots \ldots \ldots \ldots \ldots \ldots \ldots \ldots \ldots \ldots \ldots \ldots$

ACKNOWLEDGMENTS $\ldots \ldots \ldots \ldots \ldots \ldots \ldots \ldots \ldots \ldots \ldots \ldots$ vii

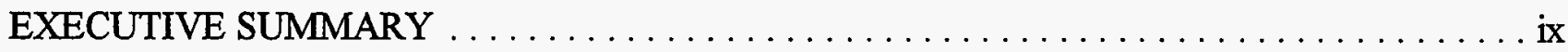

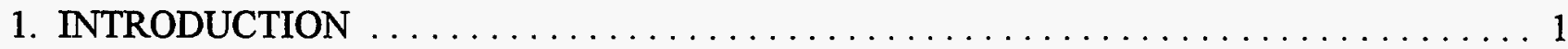

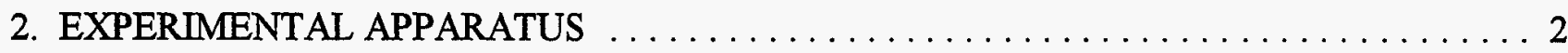

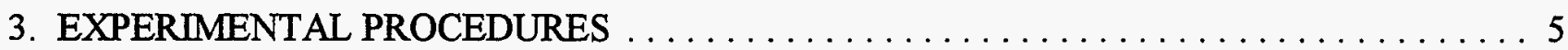

3.1 ION-EXCHANGE MATERIALS USED $\ldots \ldots \ldots \ldots \ldots \ldots \ldots \ldots \ldots \ldots \ldots \ldots \ldots$

3.2 PREPARATION OF SUPERNATANT FOR TESTS $\ldots \ldots \ldots \ldots \ldots \ldots \ldots$

3.2.1 Preparation of Initial W-27 Supernatant $\ldots \ldots \ldots \ldots \ldots \ldots \ldots \ldots$

3.2.2 Selection of Supernatant for CsRD Tests $\ldots \ldots \ldots \ldots \ldots \ldots \ldots$

3.2.2.1 CsRD SupernatantTests-Analysis of Supernatant . . . . . . . 10

3.2.2.2 CsRD Supernatant Tests-Results of Mixing Tests . ........ 11

3.2.2.3 CsRD Supernatant Tests-Results of Batch-Contact Tests . . . . . 12

3.2.2.4 CsRD Supernatant Tests-Preparation of Supernatant . . . . . 13

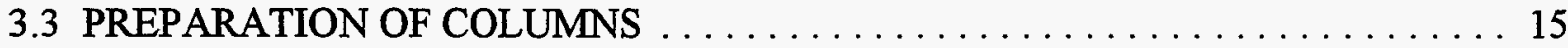

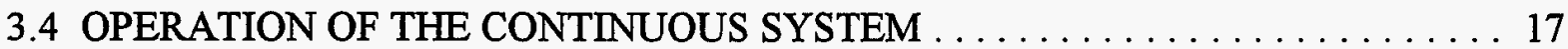

3.5 AEA TECHNOLOGIES EIX SYSTEM $\ldots \ldots \ldots \ldots \ldots \ldots \ldots \ldots \ldots \ldots \ldots \ldots \ldots$

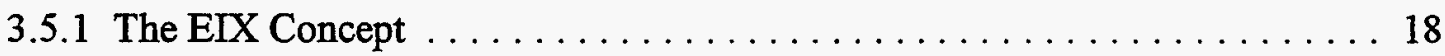

3.5.2 Description and Setup of the Experiments ................. 19

4. EXPERIMENTAL RESULTS ................................ 23

4.1 PREPARATION OF SUPERNATANT FOR OPERATION $\ldots \ldots \ldots \ldots \ldots \ldots \ldots 23$

4.2 SUPERLIG $^{\circledR}$ 644C AT $1 N$ HYDROXIDE AND $3.5 \mathrm{CV} / \mathrm{h} \ldots \ldots \ldots \ldots \ldots \ldots 24$

4.3 RF RESIN AT $1 N$ HYDROXIDE AND $3.5 \mathrm{CV} / \mathrm{h} \ldots \ldots \ldots \ldots \ldots \ldots \ldots \ldots$

4.4 CST-38 B AT $1 N$ HYDROXIDE AND $7.5 \times 10^{-5} M$ CESIUM $\ldots \ldots \ldots \ldots \ldots \ldots 32$

4.5 CST-0001 AT $1 N$ HYDROXIDE AND $7.5 \times 10^{-5} M$ CESIUM $\ldots \ldots \ldots \ldots . \ldots 35$

4.6 CST-0003, CsRD QUALIFICATION EXPERIMENT USING MVST W-29 . . . 36

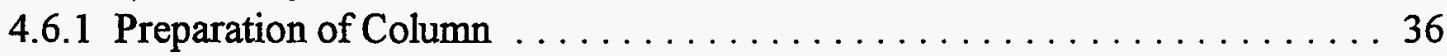

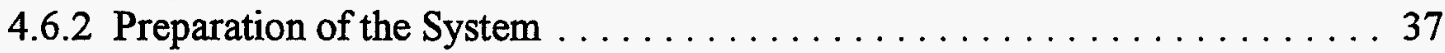

4.6.3 Conduct of CST Loading . . . . . . . . . . . . . . . . . . . . . 38

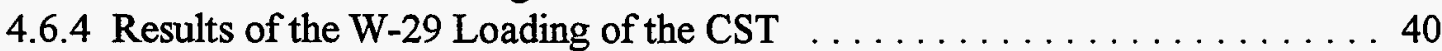

4.7 RF COLUMN TEST USING AEA RF AND W-27 SUPERNATANT . . . . . . 46

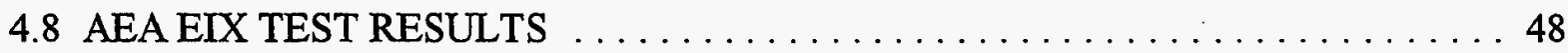

4.8.1 First Loading and EIX Elution of Test Cell $1 \ldots \ldots \ldots \ldots \ldots \ldots$ 
4.8.2 Second Loading and EIX Elution of Test Cell $1 \ldots \ldots \ldots \ldots \ldots \ldots$

4.8.3 First Loading and EIX Elution of Test Cell $2 \ldots \ldots \ldots \ldots \ldots \ldots$

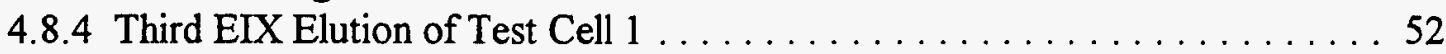

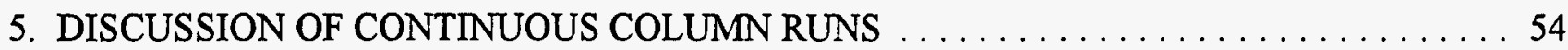

5.1 COMPARISON OF THE CONTINUOUS RUNS WITH BATCH

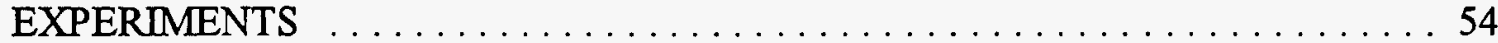

5.2 COMPARISON WITH RESULTS FROM OTHER CONTINUOUS

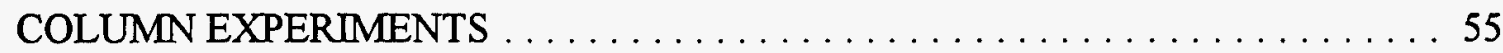

5.3 PROBLEMS ASSOCIATED WITH THE RUNS $\ldots \ldots \ldots \ldots \ldots \ldots \ldots$

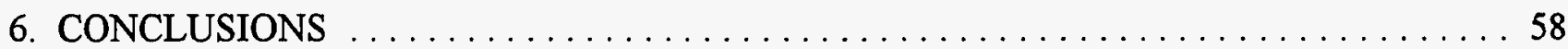

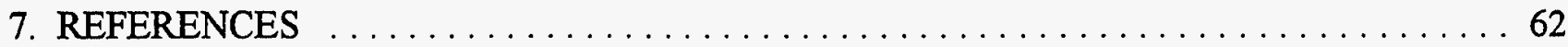




\section{LIST OF FIGURES}

$\underline{\text { Figure }} \underline{\text { Page }}$

ES-1 Flow diagram of ORNL cesium removal system $\ldots \ldots \ldots \ldots \ldots \ldots \ldots \ldots$

ES-2 Loading curves for ORNL-tested cesium sorbents at $\mathrm{pH} 13.3$ using MVST W-27 . . . . xiv

ES-3 Loading curves using MVST W-27 feed adjusted to $\mathrm{pH} 14 \ldots \ldots \ldots \ldots \ldots$. . . . . . xiv

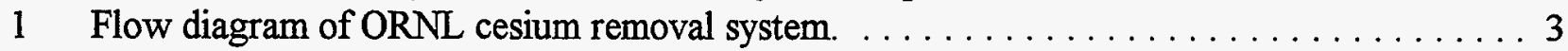

2 Batch contacts of IE-911 with proposed supernatants for the CsRD . . . . . . . . . . . . 14

3 Electrochemical elution of ion-exchange resins . . . . . . . . . . . . . . . . . . 19

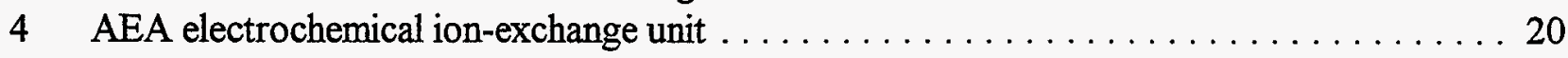

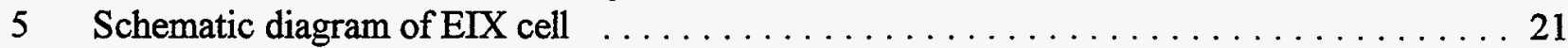

6 Flow diagram for the AEA ELX test in the ORNL flow system . . . . . . . . . . . . . 22

7 Loading curves for SuperLig ${ }^{\otimes} 644 \mathrm{C}$ cycles at $3.5 \mathrm{CV} / \mathrm{h}$ at $1 \mathrm{MOH}$ and $7.5 \times 10^{-5} \mathrm{M} \mathrm{Cs} \ldots 26$

8 Elution curves for SuperLig ${ }^{\otimes} 644 \mathrm{C}$ cycles $\ldots \ldots \ldots \ldots \ldots \ldots \ldots \ldots$

9 Loading curve for the RF resin at $3.5 \mathrm{CV} / \mathrm{h}$, using MVST W-27 supernatant at $\mathrm{pH} 14 \ldots 31$

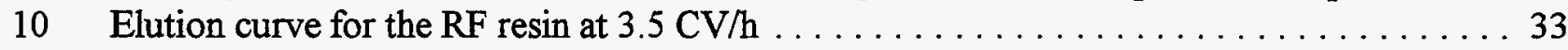

11 Loading curves for CST-38B and -0001 at $6 \mathrm{CV} / \mathrm{h}$, using supernatant at $\mathrm{pH} 14$ and

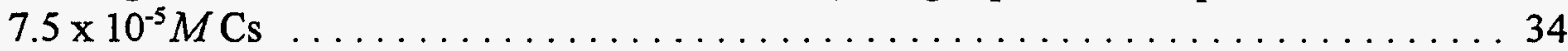

12 Loading curve for CST (lot -0003) at $6 \mathrm{CV} / \mathrm{h}$ (August 12-16, 1996), using commercial

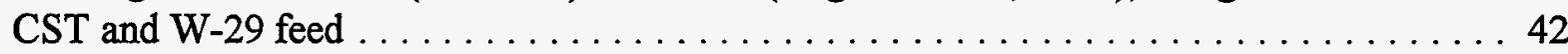

13 Comparison of the loadings of the CST $(-38 \mathrm{~B},-0001$, and -0003$)$ materials, using

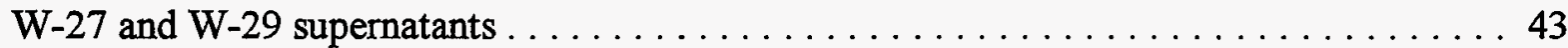

14 Loading curves for cesium, strontium, uranium, and lead, using CST-0003 and W-29 supernatant . . . . . . . . . . . . . . . . . . . . . . 44

15 Loading curve for RF resin (AEA batch) with W-27 supernatant at $0.1 M \mathrm{OH}$ and

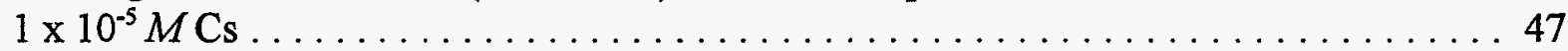

16 Loading curves for the AEA EIX test cells, using RF resin and W-27 supernatant

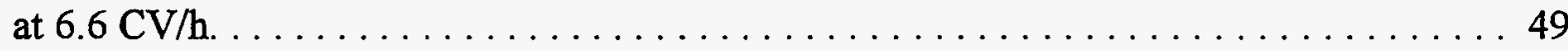

17 Electrical results of the elutions of the AEA EIX cells using the electrochemical

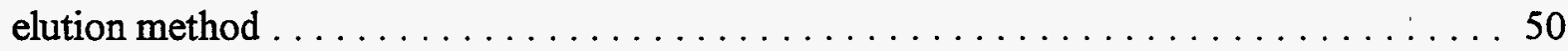

18 Cesium results for the electrochemical elutions of the EIX cells $\ldots \ldots \ldots \ldots \ldots \ldots$

19 Comparison of the recalculated results of the SuperLig ${ }^{\circledR} 644 \mathrm{C}$ tests $\ldots \ldots \ldots \ldots 7$

20 Comparison of sorbents using MVST W-27 adjusted to $\mathrm{pH} 13.3 \ldots \ldots \ldots \ldots$

21 Comparison of cesium sorbents using MVST W-27 adjusted to $\mathrm{pH} 14 \ldots \ldots 0$

\section{LIST OF TABLES}

Table

ES-1 Analyses of the MVST W-27 and W-29 supernatants . . . . . . . . . . . . xii

ES-2 Comparison of sorbent results for ORNL Cell $\mathrm{C}$ continuous-column cesium-

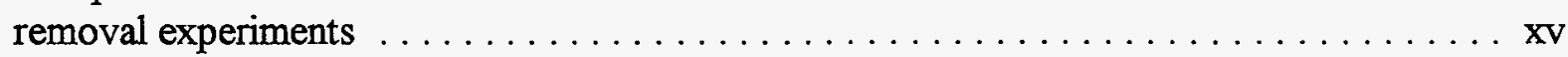

1 Analyses of the MVST $\mathrm{W}-27$ supernatant $(\mathrm{pH} \mathrm{13}) \ldots \ldots \ldots \ldots \ldots \ldots \ldots$

2 Analyses of the MVST W-27 supernatant $(\mathrm{pH} 14$ and added cold cesium) . . . . . . . 8 


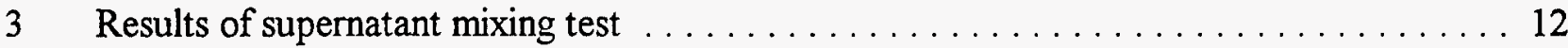

4 Test of proposed $\mathrm{pH}$ adjustment of $\mathrm{W}-27$ supernatant $\ldots \ldots \ldots \ldots \ldots \ldots \ldots \ldots$

5 Analysis of W-29 supernatant used in the CsRD qualification test $\ldots \ldots \ldots \ldots \ldots$

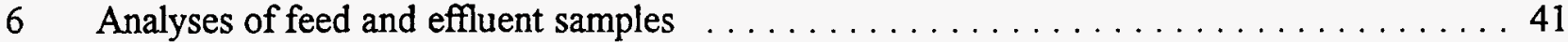

7 Comparison of the cesium sorbent experiments in Cell C, Building 4501 at ORNL . . . . 61 


\section{ACKNOWLEDGMENTS}

The authors wish to thank the U.S. Department of Energy Office of Science and Technology's Efficient Separations and Processing Cross-Cutting Program for providing funds for this work. The authors also wish to thank J. L. Collins for the method of total cesium analysis for the high-salt-concentration solutions, K. K. Anderson for the cesium analyses, and D. J. Davidson for batch-contact testing of the CSTs. They are indebted to the dedicated technical staff members of the Chemical Development Section of the Chemical Technology Division, including K. K. Anderson, S. A. Bush, C. W. Chase, T. A. Dillow, R. T. Jubin, A. J. Mattus, and R. D. Hunt, for operational support during around-the-clock operation of the experimental system. 


\section{HOT DEMONSTRATION OF PROPOSED COMMERCIAL NUCLIDE REMOVAL TECHNOLOGY: \\ PROGRESS REPORT}

EXECUTIVE SUMMARY

\section{TECHNOLOGY NEEDS}

Cesium, strontium, and technetium radionuclides constitute a small fraction of the primarily sodium and potassium salts present in supernatants that are being stored in tanks at Hanford, Oak Ridge, Savannah River, and Idaho and must be remediated. Nuclide removal technologies supplied by the U.S. Department of Energy Office of Science and Technology's Efficient Separations and Processing (ESP) Cross-Cutting Program have been previously proposed and tested in small batch and column tests using both simulated and actual supernatants. These technologies must now be tested and the most appropriate ones selected using a flow system of a scale suitable to obtain engineering data that can be applied to the design of pilot-scale equipment.

\section{DESCRIPTION OF TECHNOLOGIES}

This task involves the operation of an experimental unit designed and constructed to evaluate radionuclide removal technologies during continuous operation with actual supernatants. The equipment diagram, shown in Fig. ES-1, consists of tanks, pumps, tubing and fittings, filters, and instrumentation in a continuous-flow system in an ORNL hot cell. It provides a test bed for investigating new technologies, such as 3M's WEB and AEA Technology's EIX electrochemical elution system, and complements the comprehensive supernatant task by using larger engineeringscale, continuous equipment to verify and expand their batch studies. We support the Tanks Focus Area's (TFA's) Cesium Removal Demonstration (CsRD) at Oak Ridge by providing sorbent selection information, evaluation of proposed sorbents, and operational experience and characteristics using the sorbent and supernatant to be used in the demonstration, followed by a comparison of the smallscale with the demonstration-scale performance.

We cooperate closely with the ESP and the TFA in order, ultimately, to transfer the technologies being developed to the end user. 


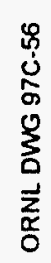
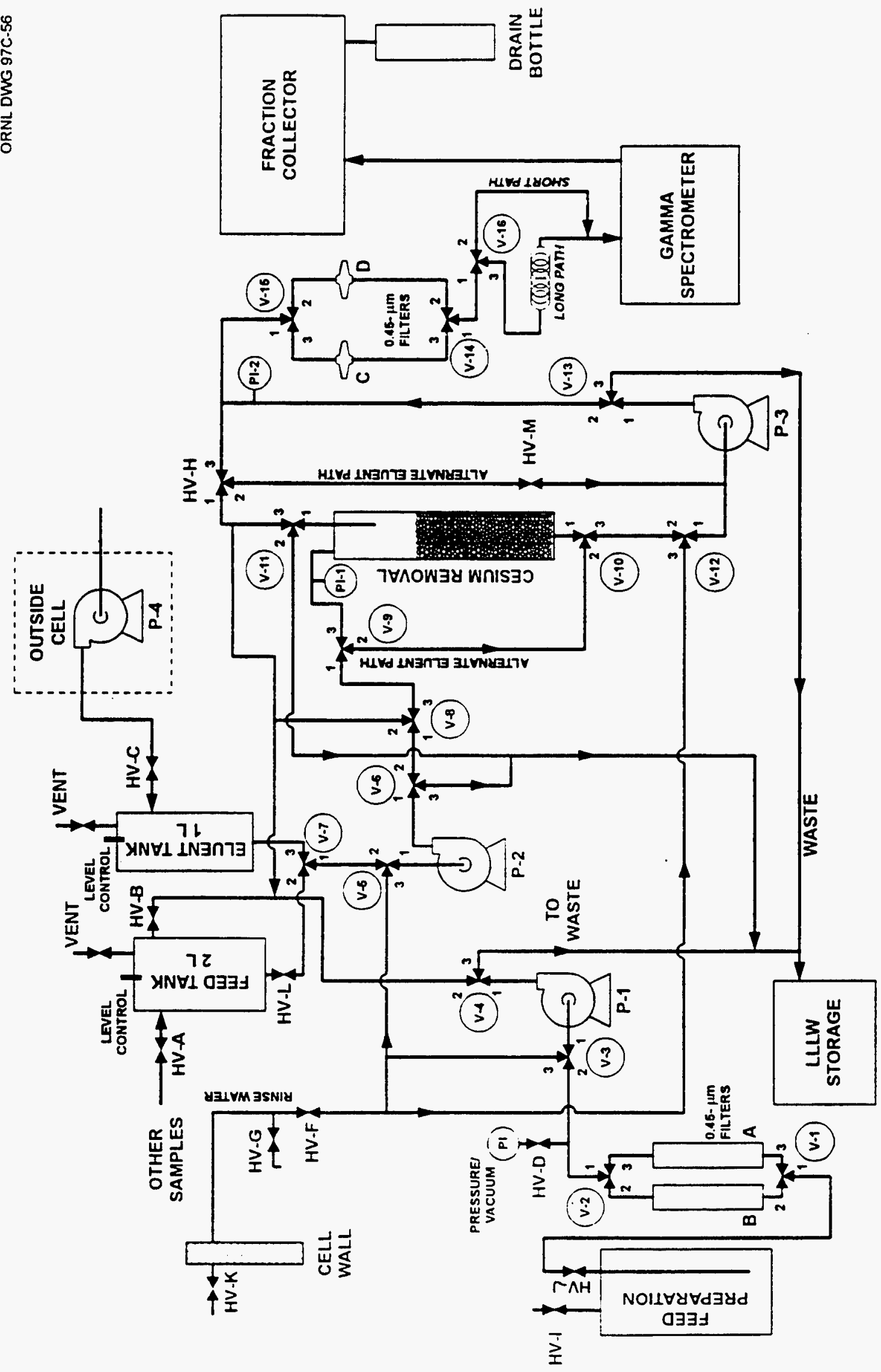

ह 


\section{TECHNICAL APPROACH}

In April 1995, a 60-L sample of supernatant was retrieved from tank W-27 of the Melton Valley Storage Tank (MVST) system and characterized. It has many similarities to supernatants in tanks at other DOE sites and, therefore, provides a common basis to evaluate different sorbents for their ability to remove cesium from actual radioactive storage tank supernatant. The sorbents were tested using a 1.5 - by $15-\mathrm{cm}$ column containing about $10-12 \mathrm{~cm}^{3}$ of sorbent at flow rates of 3-9 column volumes (CV) per hour. Other sorbent-containing apparatus such as the 3M WEB and the AEA EIX rig can also be easily connected to the system. The breakthrough of cesium from the sorbent is followed by an on-line gamma spectrometer, and the effluent is also fractionated for chemical and radiological analyses. Sorbents that can be eluted and regenerated are cycled in place through loading, elution, and regeneration steps. Sorbents can also be analyzed by removal from the cell and counting on another gamma spectrometer to determine the total loading and/or the efficiency of elution.

The $\mathrm{pH}$ of the MVST W-27 supernatant used for the cesium absorber tests was originally at 7.4 but was adjusted back to the levels found in other tanks ( 12.5-13.3) by adding sodium hydroxide $(\mathrm{NaOH})$ pellets. For some tests designed to simulate conditions at other DOE sites, the $\mathrm{pH}$ was increased to 14, and cold cesium nitrate was added to give a total cesium concentration seven to ten times that of the original concentration. The supernatant chosen for the CsRD was prepared by adding $50 \%$ caustic solution to tank W-27, settling for 2 weeks, and then pumping approximately $83,000 \mathrm{~L}$ to tank W-29 to mix with the supernatant heel still present after previous operations with W-29. The mixed W-29 was allowed to settle for 1 month and then sampled for the CsRD qualification tests.

The $\mathrm{pH}$ of the W-27 supernatant (April 1995) was adjusted to 13.3; then the mixture was allowed to settle before being filtered. The filtrate contained about $3.2 \times 10^{5} \mathrm{~Bq}{ }^{137} \mathrm{Cs} / \mathrm{mL}, 7.1 \mathrm{x}$ $10^{-6} \mathrm{M}$ total cesium, about $0.26 \mathrm{M}$ potassium, $4.7 \mathrm{M}$ sodium, and $5.2 \mathrm{M}$ nitrate. After being adjusted to $\mathrm{pH} 14$ with $1 \mathrm{~N}$ hydroxide, it contained $3.4 \times 10^{5} \mathrm{~Bq}{ }^{137} \mathrm{Cs} / \mathrm{mL}, 1.0 \times 10^{-5} \mathrm{M}$ total cesium, $0.31 \mathrm{M}$ potassium, and $7.5 \times 10^{-5} \mathrm{M}$ total (5.52 $\mathrm{M}$ plus added cesium) Cs. The W-29 supernatant, which had a pH of 12.68 , contained $4.15 \mathrm{M}$ sodium, $0.38 \mathrm{M}$ potassium, $4.6 \times 10^{5} \mathrm{~Bq}{ }^{137} \mathrm{Cs} / \mathrm{mL}, 4.3 \times 10^{-6} \mathrm{M}$ total Cs, $4.0 \mathrm{M}$ nitrate, and $0.44 \mathrm{M}$ nitrite. Compositions of the two supernatants are given in Table ES-1. The ${ }^{137} \mathrm{Cs}$ level in MVST supernatants is one to two orders of magnitude less than that 
Table ES-1. Analyses of the MVST W-27 and W-29 supernatants

\begin{tabular}{|c|c|c|c|}
\hline & $\begin{array}{c}\text { MVST W-27. } \\
\text { pH } 13.3 \\
\end{array}$ & $\begin{array}{c}\text { MVST W-27. } \\
\text { pH } \mathbf{1 4 . 0 2} \\
\end{array}$ & $\begin{array}{c}\text { MVST W-29. } \\
\text { pH } 12.68\end{array}$ \\
\hline \multicolumn{4}{|c|}{$\begin{array}{l}\text { Radiochemicals, } \\
\mathrm{Bq} / \mathrm{mL}\end{array}$} \\
\hline${ }^{60} \mathrm{Co}$ & 680 & 330 & 500 \\
\hline${ }^{137} \mathrm{Cs}$ & 320,000 & 340,000 & 460,000 \\
\hline${ }^{134} \mathrm{Cs}$ & 1,400 & 920 & 7,600 \\
\hline${ }^{90} \mathrm{Sr}$ & 65,000 & 31,000 & 4,100 \\
\hline${ }^{99} \mathrm{Tc}$ & 270 & & 342 \\
\hline Gross alpha & 0.9 & 0.4 & 30 \\
\hline Gross beta & 525,000 & 430,000 & 550,000 \\
\hline \multicolumn{4}{|l|}{$\begin{array}{l}\text { Cations/anions, } \\
\mathrm{mg} / \mathrm{L}\end{array}$} \\
\hline $\mathrm{Al}$ & 0.847 & $<0.146$ & 4.17 \\
\hline As & 0.0089 & $<0.0250$ & $<2.5 \mathrm{E}-1$ \\
\hline $\mathrm{Ba}$ & 8.04 & 5.61 & 0.865 \\
\hline $\mathrm{Ca}$ & 89.1 & 3.1 & 1.42 \\
\hline $\mathrm{Cd}$ & 0.22 & $<0.11$ & 0.24 \\
\hline $\mathrm{Cr}$ & 2.96 & 3.49 & 3.44 \\
\hline Cs & 0.935 & 9.95 & 0.58 \\
\hline $\mathrm{Cu}$ & $<0.0319$ & 0.15 & 0.07 \\
\hline $\mathrm{Hg}$ & 0.09 & 0.117 & 0.258 \\
\hline $\mathrm{K}$ & 10,300 & 12,000 & 14,700 \\
\hline $\mathrm{Na}$ & 113,000 & 127,000 & 95,400 \\
\hline $\mathrm{Ni}$ & 1.22 & 0.73 & 1.04 \\
\hline $\mathrm{Pb}$ & 0.0092 & $<10$ & 2.89 \\
\hline $\mathrm{Rb}$ & 1.1 & 2.06 & 1.28 \\
\hline $\mathrm{Si}$ & & 29.3 & 44.1 \\
\hline $\mathrm{Sr}$ & & 26.3 & 1.65 \\
\hline$U$ & $<1.0$ & 0.485 & 13.3 \\
\hline $\mathrm{Zn}$ & 0.473 & $<0.148$ & 1.35 \\
\hline $\mathrm{Br}$ & 288 & $<50.0$ & \\
\hline $\mathrm{Cl}$ & 3,180 & 2,960 & 3,050 \\
\hline $\mathrm{NO}_{2}$ & & 2,720 & 20,400 \\
\hline $\mathrm{NO}_{3}$ & 322,000 & 298,000 & 250,000 \\
\hline $\mathrm{SO}_{4}$ & 1,540 & 1,380 & 15,506 \\
\hline $\mathrm{TIC}, \mathrm{mg} / \mathrm{L}$ & & 300 & 980 \\
\hline $\mathrm{TOC}, \mathrm{mg} / \mathrm{L}$ & & 390 & 500 \\
\hline Density & 1.27 & 1.30 & 1.233 \\
\hline $\mathrm{TDS}, \mathrm{mg} / \mathrm{L}$ & & 79,000 & 81,000 \\
\hline $\mathrm{TS}, \mathrm{mg} / \mathrm{L}$ & & 580,000 & 390,000 \\
\hline $\mathrm{TSS}, \mathrm{mg} / \mathrm{L}$ & & 500,000 & 310,000 \\
\hline $\mathrm{Na} / \mathrm{Cs}$ & 701,451 & 12,764 & 164,483 \\
\hline $\mathrm{K} / \mathrm{Cs}$ & 37,446 & 1,206 & 25,345 \\
\hline Total anion $M$ & 5.3897 & 6.0063 & 4.4754 \\
\hline Total cation $M$ & 5.1983 & 5.8320 & 4.5256 \\
\hline Difference & 0.1914 & 0.1743 & -0.0503 \\
\hline
\end{tabular}


found in some Hanford tank supernatants. The cesium level after cold cesium had been added approximates the value for Hanford tanks 101-SY and 103-SY $\left(7 \times 10^{-5} \mathrm{M}\right)$ and also the DSSF simulant. The high-cesium feed has a sodium/cesium molar ratio of about $7.4 \times 10^{4}$ and a sodium/ potassium ratio of 18 .

\section{ACCOMPLISHMENTS}

Installation of the experimental equipment in the hot cell, development of the procedures to be used, and several sorbent tests were completed in FY 1995-96. Six different sorbents and resins were recommended by the ESP, based on previous screening tests at Hanford, Sandia, Los Alamos, Savannah River, and Oak Ridge. Each was tested in continuous loading tests using W-27 supernatant at $\mathrm{pH} 13.3$ and $7 \times 10^{-6} \mathrm{M}$ cesium and/or $\mathrm{pH} 14.0$ and $7.5 \times 10^{-5} \mathrm{M}$ cesium. Included were (1) two different lots of resorcinol-formaldehyde (RF) resin prepared by Boulder Scientific; (2) IBC Advanced Technologies SuperLig ${ }^{\circledR}$ 644C, batch 3695-GM1 121; (3) Rohm \& Haas CS-100 resin; (4) 3M SLIG WWL 644 WEB with SuperLig ${ }^{\circledR} 644$ embedded; (5) granular crystalline silicotitanates (CSTs) developed by Sandia National Laboratories/Texas A\&M and supplied by UOP as IONSIV ${ }^{\circledR}$ IE-911 (lots 07398-38B, 999096810001, and 99909610003); and (6) granular potassium cobalt hexacyanoferrate supplied by Eichrom Industries. A set of tests was completed using the AEA EIX process for electrochemical elution using RF resin and W-27 supernatant. The results of these tests are summarized in Figs. ES-2 and ES-3 and Table ES-2.

We provided direct input to the CsRD project for sorbent selection. The CSTs were recommended for the project, based on the best $\mathrm{CV}$ value at $50 \%$ breakthrough, highest test-to-test consistency, and fewest operational difficulties using the MVST W-27 supernatant. We also helped select the supernatant for the CsRD, performed the qualification tests for the supernatant and sorbent, and provided ${ }^{137} \mathrm{Cs}$-loaded CST sorbent for both waste acceptance criteria and waste-form development testing.

\section{EXPERIMENTAL RESULTS}

3M Slig 644 WWL WEB material was contained in a Gelman 25-mm in-line stainless steel filter holder with a filter volume (FV) of $1.29 \mathrm{~mL}$. The apparatus was loaded at $1 \mathrm{~mL} / \mathrm{min}(49.78 \mathrm{FV} / \mathrm{h})$ 
ORNL DWG 97C-354

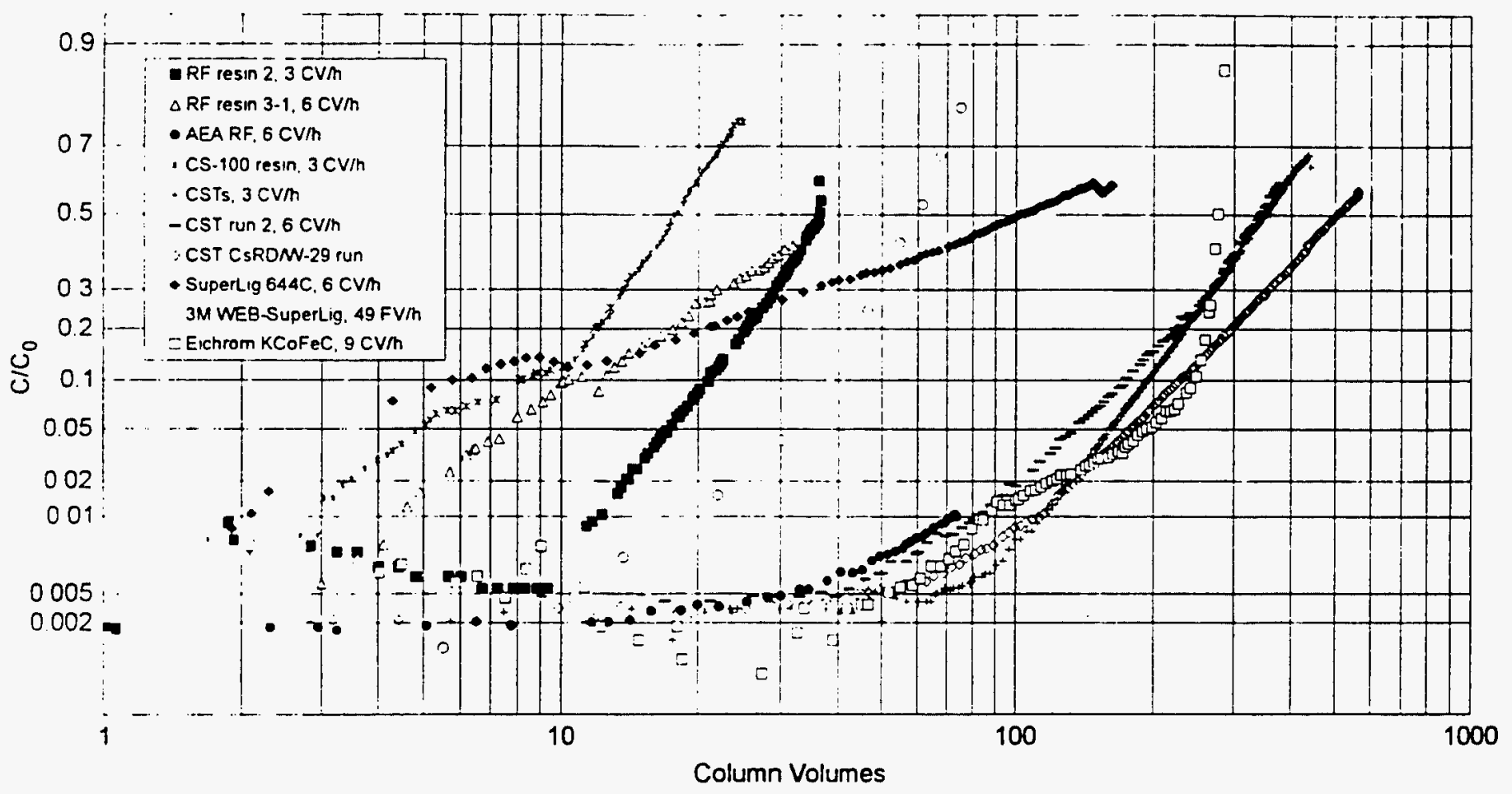

Fig. ES-2. Loading curves for ORNL-tested cesium sorbents at pH 13.3 using MVST W-27.

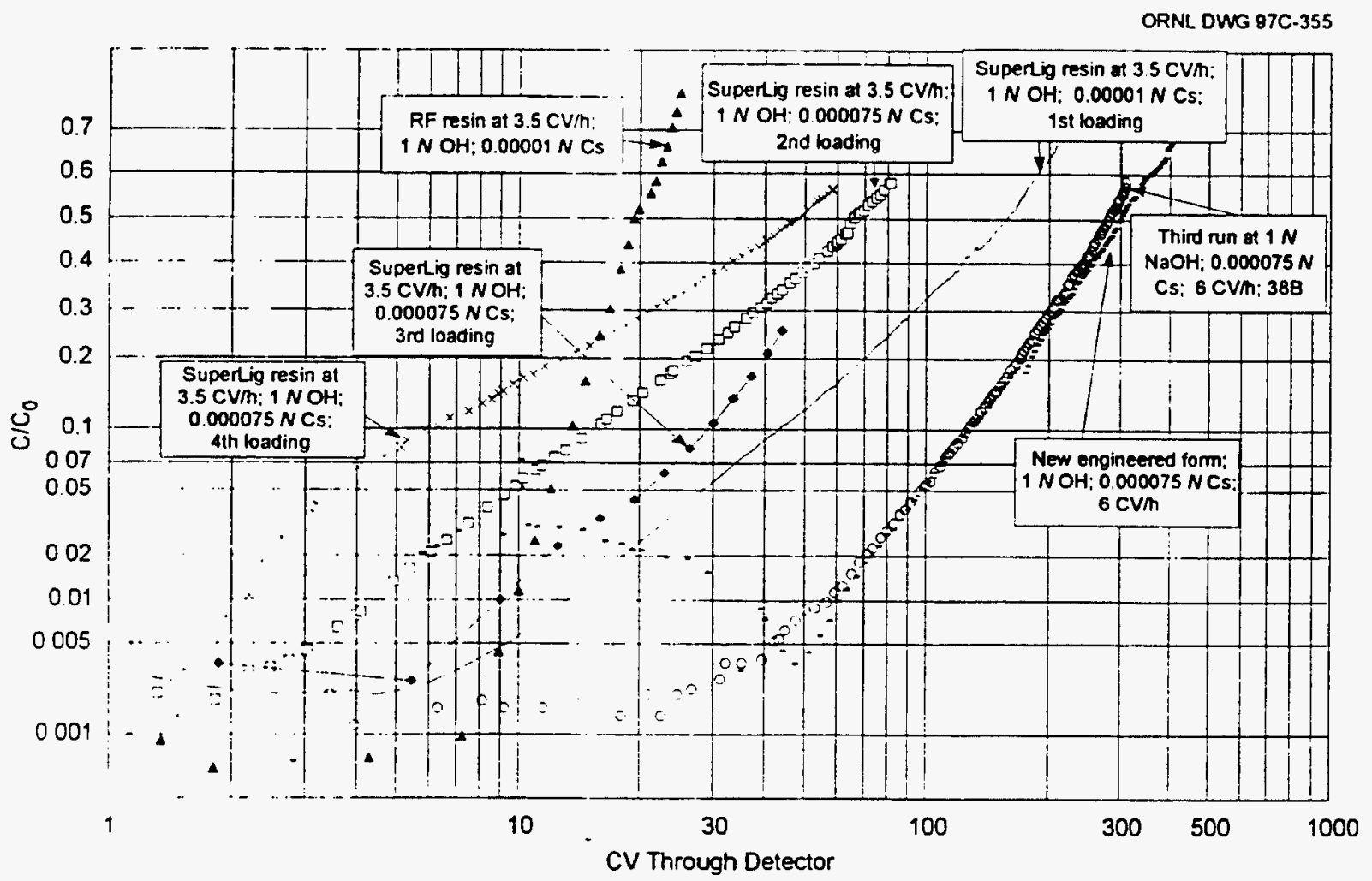

Fig. ES-3. Loading curves using MVST W-27 feed adjusted to pH 14. 
Table ES-2. Comparison of sorbent results for ORNL Cell C continuous-column cesium-removal experiments

\begin{tabular}{|c|c|c|c|c|c|c|c|}
\hline \multirow[b]{2}{*}{ Sorbent } & \multirow{2}{*}{$\begin{array}{c}\text { MVST W-27 } \\
\text { feed supernatant }\end{array}$} & \multirow{2}{*}{$\begin{array}{c}\text { Flow rate } \\
\text { (CV/h) }\end{array}$} & \multirow{2}{*}{$\begin{array}{c}\text { Loading } \\
\text { cycles }\end{array}$} & \multicolumn{3}{|c|}{$\begin{array}{c}\mathrm{CV} \text { to } \\
\text { breakthrough }\end{array}$} & \multirow[b]{2}{*}{ Comments } \\
\hline & & & & $1 \%$ & $10 \%$ & $50 \%$ & \\
\hline CS-100 & $\mathrm{pH} 13.3 ; \mathrm{Cs}=7.5 \mathrm{E}-6 M$ & 3 & 1 & 3 & 7 & 18 & No longer commercial \\
\hline RF (Bibler-1995) & $\mathrm{pH} 13.3 ; \mathrm{Cs}=7.5 \mathrm{E}-6 \mathrm{M}$ & 3 & 1 & 12 & 20 & 35 & Color; shrink/swell \\
\hline RF (Bibler-1995) & $\mathrm{pH} 13.3 ; \mathrm{Cs}=7.5 \mathrm{E}-6 M$ & 6 & 5 & 4 & 11 & 40 & Color; operational \\
\hline RF (Bibler-1995) & $\mathrm{pH} 13.3 ; \mathrm{Cs}=7.5 \mathrm{E}-6 M$ & 7 & 1 & 7.5 & 17 & 48 & Color \\
\hline RF (REDC-Bibler) & $\mathrm{pH} 14.02 ; \mathrm{Cs}=1 \mathrm{E}-5 \mathrm{M}$ & 6 & 1 & 10 & 14 & 18 & Color \\
\hline RF (AEA-BSC-187) & pH 13.3 & 6 & 1 & 65 & 140 & & Color; poor elution \\
\hline SuperLig $^{\circledR} 644 \mathrm{C}$ & pH 13.3 & 3 & 1 & 20 & 65 & & $\begin{array}{l}\text { Color; low density; } \\
\text { swell/shrink }\end{array}$ \\
\hline SuperLig $^{\circledR} 644 \mathrm{C}$ & $\mathrm{pH} 13.3$ & 6 & 1 & 1 & 10 & 100 & $\begin{array}{l}\text { Color; low density; } \\
\text { swell/shrink }\end{array}$ \\
\hline SuperLig $^{\circledR} 644 \mathrm{C}$ & $\begin{array}{l}\mathrm{pH} 14.02 ; \mathrm{Cs}=1.1 \mathrm{E}-5 ;(1) \\
7.5 \mathrm{E}-5 M(2-4)\end{array}$ & 3.5 & 4 & $\begin{array}{r}15 \\
4.5 \\
15 \\
2\end{array}$ & $\begin{array}{r}46 \\
16 \\
31 \\
6\end{array}$ & $\begin{array}{r}166 \\
70 \\
70 \\
50\end{array}$ & $\begin{array}{l}\text { Color; good elution; } \\
\text { volume changes; } \\
\text { poor reproducibility }\end{array}$ \\
\hline 3M SLC WEB & $\mathrm{pH} 13.3$ & 49.8 & 1 & 18 & 38 & 60 & Color; swell; poor elution \\
\hline $\mathrm{KCoFeC}$ & $\mathrm{pH} 13.3$ & 9 & 1 & 85 & 250 & 250 & Disintegrates at $\mathrm{pH}$; fines \\
\hline CST-38B & $\mathrm{pH} 13.3$ & 3 & 1 & 114 & 192 & 350 & No problems \\
\hline CST-38B & $\mathrm{pH} 13.3$ & 6 & 1 & 82 & 174 & 342 & No problems \\
\hline CST-38B & $\mathrm{pH} 14.02 ; \mathrm{Cs}=7.5 \mathrm{E}-5 \mathrm{M}$ & 6 & 1 & 55 & 123 & 273 & No problems \\
\hline
\end{tabular}


in an upflow mode through one loading/elution/regeneration cycle. Brown color left the WEB filter for several FV after the supernatant feed began. The loading was $65 \mathrm{FV}$ to $50 \%$ breakthrough. The filter was eluted with $0.5 \mathrm{NHNO}_{3}$ and regenerated with caustic solution.

Eichrom KCoFeC granular sorbent (7.272 g of lot JW-40-021) was loaded at $9 \mathrm{CV} / \mathrm{h}$ using W-27 supernatant at $\mathrm{pH}$ 13.32. Normal column operation with low cesium breakthrough continued for over $250 \mathrm{CV}$, but then the sorbent began to disintegrate and the level of cesium in the effluent increased so rapidly that it could not be removed by using $0.2-\mu \mathrm{m}$ filters.

SuperLig ${ }^{\otimes} 64 \mathrm{C}$ was run at $6 \mathrm{CV} / \mathrm{h}$ using $3.779 \mathrm{~g}$ of dry resin (11.2-mL volume) using W-27 supernatant at $\mathrm{pH}$ 13.3. A considerable amount of color was removed with the initial few column volumes of feed through the column. After the breakthrough had reached $50 \%$ at about $100 \mathrm{CV}$, the loaded cesium was eluted with $0.5 \mathrm{NHNO}_{3}$ at $3 \mathrm{CV} / \mathrm{h}$. Colored liquid also accompanied the first few column volumes of acid. The elution curve, which was very sharp, was $95 \%$ complete in $6 \mathrm{CV}$. The resin has a very low density and could be compressed easily (30\% or greater), so calculations were adjusted for the smaller column volume due to compression, giving a revised $50 \%$ breakthrough of about $138 \mathrm{CV}$.

SuperLig $644 \mathrm{C}$ was loaded with W-27 at pH 14.0 using a special weighted bed follower, developed by J. L. Collins, to compact the bed. Loading was at $3.5 \mathrm{CV} / \mathrm{h}$; elution used $0.5 \mathrm{~N} \mathrm{HNO}_{3}$, and regeneration used $2 \mathrm{~N} \mathrm{NaOH}$. The first cycle had a total cesium concentration of $1.1 \times 10^{-5} \mathrm{M}$ in the feed, and the following three had $7.5 \times 10^{-5} \mathrm{M}$ cesium. The bed volume changed by as much as $40-50 \%$ when switching from feed to distilled water, to acid, to caustic, and then feed. The $50 \%$ breakthrough point for the first loading occurred at about $167 \mathrm{CV}$. Elution was complete in about $6 \mathrm{CV}$ of $0.5 \mathrm{NHNO}_{3}$. The next three loadings (high cesium) and $50 \%$ breakthroughs occurred at 77,65 , and $50 \mathrm{CV}$, respectively, while initial breakthrough of the cesium was less than $10 \mathrm{CV}$ for all three loadings. Two of the loading curves were approximately parallel to the first curve, while the fourth curve was completely different. Color was seen at the start of each loading, as well as at each regeneration.

$\mathrm{RF}$ resin was prepared and used in three tests with $\mathrm{W}-27$ supernatant at $\mathrm{pH} 13.3$. At $7 \mathrm{CV} / \mathrm{h}, 50 \%$ breakthrough of cesium occurred at $45 \mathrm{CV}$. At $2.9 \mathrm{CV} / \mathrm{h}$, the $50 \%$ breakthrough point was at $36 \mathrm{CV}$ and the shape of the curve was similar to, but steeper than, that in the 7-CV/h RF run. In the third test, RF resin was loaded, eluted, regenerated, and then rinsed five times at $6.0 \mathrm{CV} / \mathrm{h}$. For the first $3-4 \mathrm{CV}$ of feed or regenerant through the bed, brown-colored liquid exited the bed. The $50 \%$ breakthroughs were consistent at about $45-50 \mathrm{CV}$, but some operational problems began to develop during the last two loadings. Elution 
was completed with $0.5 \mathrm{MHNO}_{3}$ at about $3 \mathrm{CV} / \mathrm{h}$, and the resin volume shrank from about $10 \mathrm{~cm}^{3}$ to about $5.5 \mathrm{~cm}^{3}$. Approximately 9-12 CV were required for cesium elution to be essentially complete.

Additional RF resin was obtained from the ORNL Radiochemical Engineering Development Center (REDC) and loaded with $\mathrm{pH} 14.0 \mathrm{~W}-27$ supernatant feed containing $1 \times 10^{-5} \mathrm{M}$ cesium at $3.5 \mathrm{CV} / \mathrm{h}$ to $70 \%$ breakthrough. A weighted bed follower, described previously, was also used during this test. Cesium initially broke through at $7 \mathrm{CV}$, and then the curve remained very steep to $50 \%$ breakthrough at about $18 \mathrm{CV}$. The elution was performed with $0.5 \mathrm{NHNO}_{3}$.

A third RF resin obtained from AEA Technologies (BSC 187) was used with the $\mathrm{pH} 13.3 \mathrm{~W}-27$ at a feed rate of $6 \mathrm{CV} / \mathrm{h}$. Although the loading was continued through $75 \mathrm{CV}$, a breakthrough of only about $1.1-1.2 \%$ was achieved. The loading curve shows that the initial breakthrough did not occur until $15 \mathrm{CV}$, and then the curve was very shallow to $1 \%$ at about $65 \mathrm{CV}$. A brown color was also evident.

Crystalline silicotitanates (CSTs) from UOP, IONSIV IE-911 lot 07398-38B, were first tested at $3 \mathrm{CV} / \mathrm{h}$ in the downflow mode using $\mathrm{pH} 13.3 \mathrm{~W}-27$ supernatant for more than $435 \mathrm{CV}$. No problems that could be attributed to the ion exchanger occurred during the continuous run of more than 6 days ( $24 \mathrm{~h} /$ day). The $1 \%$ breakthrough came after $100 \mathrm{CV}, 10 \%$ breakthrough at about $190 \mathrm{CV}$, and $50 \%$ breakthrough at $350 \mathrm{CV}$. At $6-\mathrm{CV} / \mathrm{h}$ loading, the $50 \%$ breakthrough point (at $340 \mathrm{CV}$ ) was very close to that obtained at $3 \mathrm{CV} / \mathrm{h}$. No difficulties with the system were observed during either loading.

CST-38B was loaded at $6 \mathrm{CV} / \mathrm{h}$ with W-27 supernatant at $\mathrm{pH} 14.0$ and a cesium concentration of $7.48 \times 10^{-5} M$ to greater than $55 \%$ breakthrough. The loading curve was parallel to the previous $6-\mathrm{CV} / \mathrm{h}$ curve, as expected; the $50 \%$ breakthrough occurred at $272 \mathrm{CV} \mathrm{(} 79 \%$ of the breakthrough for feed with lower cesium and hydroxide), the $10 \%$ breakthrough at $122 \mathrm{CV}$, and the $1 \%$ breakthrough at $55 \mathrm{CV}$. Again, no difficulties were observed during operation.

UOP IONSIV ${ }^{\circledR}$ IE-911 (lot 999096810001) CST, the production-engineered form of the CSTs, was loaded at $6 \mathrm{CV} / \mathrm{h}$ in a repeat of the previous run using the high-cesium feed at $\mathrm{pH} 14$. Feed with a lower cesium concentration was used in the last $150 \mathrm{CV}$, however. The sorbent was treated to remove fines because the CST was fairly dusty and the water was "milky" after the first contact. Initial flow stabilization problems caused an erratic startup, but once flow was stabilized, the breakthrough curve returned to background level before starting the normal increase. The 50\% breakthrough occurred at $294 \mathrm{CV}$, the $10 \%$ breakthrough at $127 \mathrm{CV}$, and the $1 \%$ breakthrough at about $61 \mathrm{CV}$. This CST was about 3-10\% better than the $-38 \mathrm{~B}$ with regard to breakthrough points. Because it is about $10 \%$ less dense than the $-38 \mathrm{~B}$ 
material, the performance per mass of sorbent was roughly $10-20 \%$ better. Although no difficulties with the system were observed during operation, it was noted that the $\mathrm{pH}$ of the supernatant was reduced by the CST as it passed through the column for the first $100 \mathrm{CV}$. This is an important consideration for any supernatant containing soluble aluminum, which could precipitate in and on the bed if the $\mathrm{pH}$ drops even slightly.

For the CsRD qualification of CST IONSIV IE-911, lot 99909681003 and W-29 supernatant, the CST was pretreated to $\mathrm{pH} 12.6$ with caustic and then fluidized to remove fines using a simulant that was $4.5 \mathrm{M}$ in $\mathrm{NaNO}_{3}$ and $0.1 \mathrm{~N}$ in $\mathrm{NaOH}$. The W-29 supernatant was sampled from the tank and then placed in the cell. The loading was continued at $6 \mathrm{CV} / \mathrm{h}$ for $560 \mathrm{CV}$, with a minor upset after $50 \mathrm{CV}$; however, it was completed uneventfully during the next $500 \mathrm{CV}$. Data for the different cesium analyses gave $50 \%$ breakthroughs of 503.7 to $546.2 \mathrm{CV}$ for ${ }^{137} \mathrm{Cs}$ analyses. These analyses showed that the CST loaded Ba, $\mathrm{Ca}, \mathrm{Cs}$, gross alpha and beta, ${ }^{90} \mathrm{Sr}, \mathrm{U}$, and $\mathrm{Zn}$, but not $\mathrm{Hg}, \mathrm{Cd},{ }^{99} \mathrm{Tc}, \mathrm{Cr},{ }^{106} \mathrm{Ru}, \mathrm{Rb}, \mathrm{Ni}, \mathrm{Na}, \mathrm{K}$, and $\mathrm{Al}$. The increase in CV to $50 \%$ for the comparable CST runs with W-27 and W-29 was about 345 to $505 \mathrm{CV}$, or a $45 \%$ increase due to a lower level of total cesium, a lower nitrate level, and a lower $\mathrm{pH}$ in the W-29. The apparent breakthroughs for the $\mathrm{U},{ }^{90} \mathrm{Sr}$, and $\mathrm{Pb}$ were 433,1164 , and $3327 \mathrm{CV}$, respectively. Sorbent from the loaded column was subjected to a modified TCLP procedure and showed no unacceptable values.

\section{RESULTS}

Comparison of the column data for all sorbents using the W-27 feed with data obtained for simulant and actual supernatants at other sites showed good agreement and predictability from batch equilibrium to column testing, except for the RF resin, which varied significantly from batch to batch. Further comparisons must take into account not only cesium concentrations, but the $\mathrm{pH}$, the other anions and cations present in the supernatant, and the ratios of other cations to the cesium concentration.

These comparative evaluations helped provide critical data for the selection of the sorbent for the $\mathrm{CsRD}$, as well as data applicable to other DOE sites. In addition to the cesium removal capacity of the materials tested, the operational characteristics during continuous loading experiments were monitored. All of the organic sorbents - RF, SuperLig ${ }^{\otimes}$, and the 3M SLIG 644 WWL WEB - produced colored products upon the first introduction of feed or during regeneration after elution. They also exhibited volume changes during various stages of the preparation, loading, elution, and regeneration steps. The high 
$\mathrm{pH}$ of the feed supernatant to the Eichrom $\mathrm{KCoFeC}$ resulted in its chemical breakdown and loss in the column effluent. No operational problems were noted for the CSTs.

\section{BENEFITS/USERS}

The technologies evaluated in this task are expected to apply to the remediation of tank waste supernatants at most DOE sites, particularly highly alkaline supernatants that contain high concentrations of salts. Separation and concentration of the soluble radionuclides, particularly cesium, would result in a much smaller volume of radioactive waste for disposal or long-term storage. Removal of the radioactive components would also reduce shielding requirements and facilitate downstream handling for removing nitrates and any other toxic or hazardous components in the salt solution.

We provide the TFA's CsRD at Oak Ridge with a wide spectrum of data for the evaluation and testing of proposed sorbents as well as the results of operational experience and characteristics for a particular sorbent and supernatant selected for use in the demonstration. We use a test bed with actual supernatant for investigating any other new technologies that become available during the program. Engineering-scale equipment is applicable in our tests because of the ready availability of supernatant.

Information developed by this task is submitted to the DOE Program Manager for dissemination. Results are presented to Waste Management personnel at other DOE sites, and researchers at other sites are kept informed of progress.

\section{For further information, please contact:}

D. D. Lee

Lockheed Martin Energy Research Corp., Oak Ridge National Laboratory

P. O. Box 2008, Oak Ridge, TN 37831-6221

(423) 576-2689; Fax (423) 574-6872; E-mail: leedd@ornl.gov 


\title{
HOT DEMONSTRATION OF PROPOSED COMMERCIAL CESIUM REMOVAL TECHNOLOGY: PROGRESS REPORT
}

\author{
D. D. Lee, J. R. Travis, and M. R. Gibson
}

\section{INTRODUCTION}

The U.S. Department of Energy (DOE) is faced with remediating millions of gallons of both high-level and low-level radioactive wastes in underground storage tanks at various sites, including Oak Ridge, Hanford, Savannah River, and Idaho. A large portion of each waste exists as liquid solution (supernatant) that contains soluble radionuclides, along with high concentrations of sodium and potassium salts. The radioactivity is derived primarily from cesium (Cs), strontium ( $\mathrm{Sr}$ ), and technetium (Tc). Typically, the radionuclides constitute only a small portion (less than $0.0001 \%$ ) of the supernatant waste. If these radioactive components could be removed and concentrated, separating 1 part $\mathrm{Cs}$ from the million parts $\mathrm{Na}$, the volume of waste to be disposed of or stored as high-level waste (HLW) could be reduced by a factor of 20 to 300 . The objectives of the experiments reported here were to test and select sorbents and commercial cesium removal technologies for removing and concentrating the radioactive cesium, thereby reducing the waste to be stored or disposed of.

The sorbents selected for testing come from state-of-the-art ion-exchange materials that were primarily developed by the DOE Office of Science and Technology's Efficient Separations and Processing (ESP) Cross-Cutting Program. One major goal of these experiments was to test sorbents and support the Cesium Removal Demonstration Project (CsRD) at ORNL.

This report describes the operation of the experimental test unit that is located in Building 4501 (hot cell C) and the results using the sorbent materials tested. The experimental equipment has been operated to evaluate radionuclide removal technologies under continuous-flow operation on actual ORNL Melton Valley Storage Tank (MVST) supernatant. The MVST supernatants, as adjusted using sodium hydroxide $(\mathrm{NaOH})$ or used as received, contained lower quantities of total cesium and hydroxide, but more potassium, than many of the Hanford supernatants; however, the sodium content was approximately the same. Adjustment of the $\mathrm{pH}$ and cesium content for individual tests allowed closer comparison with some of Hanford's waste liquids. The technologies selected for evaluation were contained in columns that could be attached to the experimental flow system inside the hot cell and could be continuously fed the test 
supernatant until the cesium exhausted the capacity of the exchanger. Some of the ion-exchange materials were supplied under the other programs sponsored by the Tank Focus Area (TFA) and ESP.

The tests reported here gave direct comparisons of cesium removal operations conducted in the experimental system. A large batch of MVST supernatant from tank W-27 was initially obtained so that all sorbents were initially evaluated using the same feed. Several were then reevaluated at altered feed conditions and different flow rates, as appropriate, to test the sorption kinetics. Ion-exchange materials were tested at a scale that passed from 0.1 to $5 \mathrm{~L}$ of MVST supernatant at a prescribed flow rate continuously through the test module until the cesium reached the desired end point. The progress was measured with an in-line gamma detector. Depending on the material being tested, this end point has required from 15 to more than 500 column volumes (CV) of supernatant to pass through the module.

The work described in this report was conducted on the several different exchanger materials. Two different batches of resorcinol-formaldehyde (R-F) resin, two batches of Superlig ${ }^{\otimes} 644 \mathrm{C}$, and three batches of the engineered forms of crystalline silicotitanate were used. The Superlig ${ }^{\circledR} 644 \mathrm{C}$ and initial CST materials were supplied through the ESP program.

\section{EXPERIMENTAL APPARATUS}

The experimental equipment for the cesium removal project in hot cell $\mathrm{C}$ of Building 4501, the procedures used during the experiments, and the results of earlier experiments have been described previously. ${ }^{1}$ The equipment, shown in Fig. 1, consisted of tanks, pumps, tubing and fittings, filters, instrumentation, and connections for testing radioactive ion-exchange removal materials in a continuous-flow system. The ion-exchange materials, which were contained in columns as loose sorbents, were examined for cesium removal only. Modifications were made for the CsRD qualification test by passing the supernatant through a $25-\mu \mathrm{m}$ filter as it was pumped to the column feed tank. In the case of the AEA Technologies (AEA) Electrochemical Ion Exchange (EIX) tests, the EIX test rig was inserted in place of the normal ion-exchange column.

The system was operated continuously with in-line monitoring of the column effluent to detect cesium breakthroughs from the material in the module. The monitor was a sodium iodide detector in a leadshielded container connected to a power supply, amplifier, and Nuclear Data multichannel analyzer system 


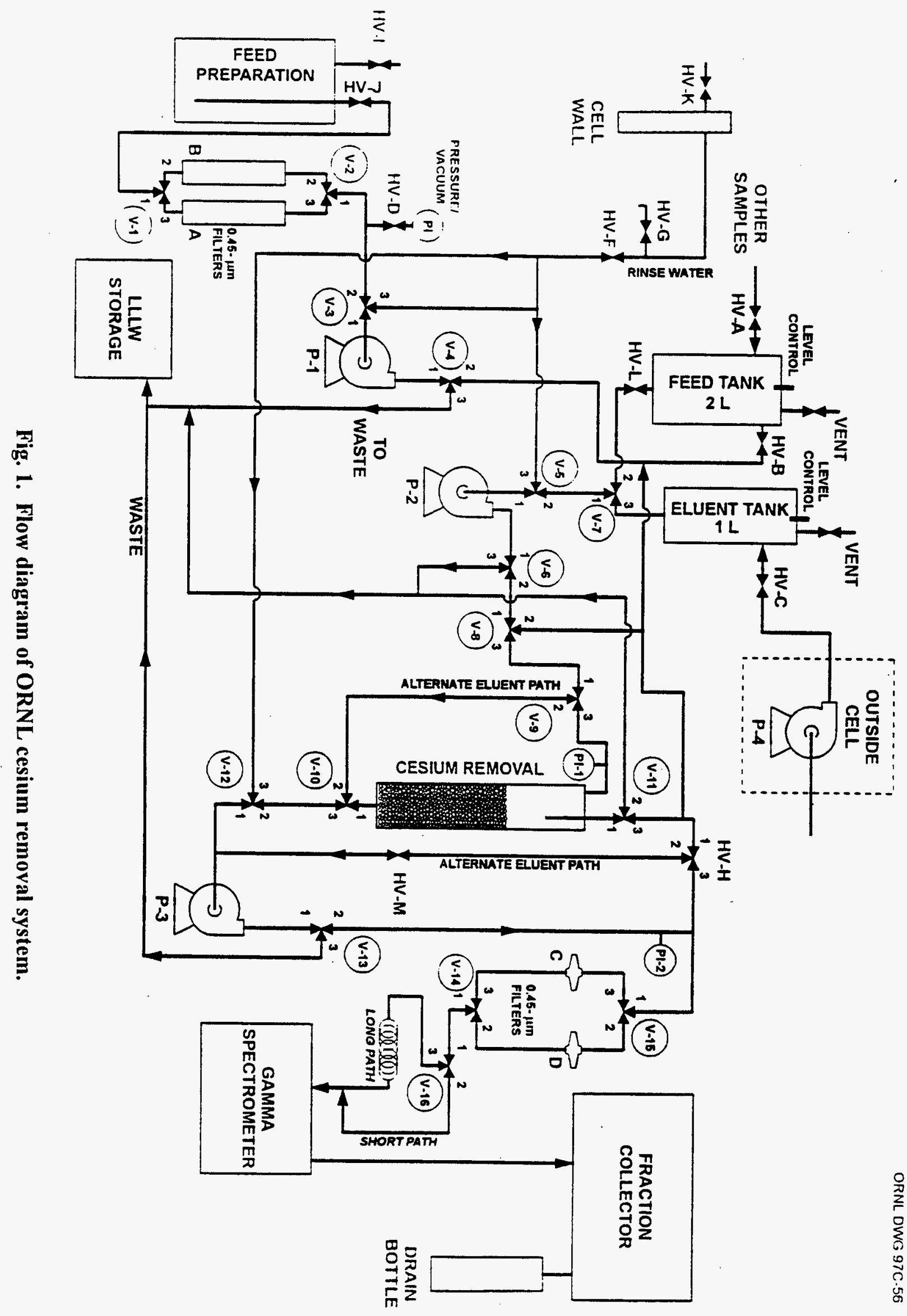


outside the cell. The column effluent passed by the detector head inside a $6.4-\mathrm{mm}-\mathrm{OD}$ by $4.8-\mathrm{mm}-\mathrm{ID}$ polyethylene tube that had $5 \mathrm{~cm}$ of tubing exposed to the detector head. Flow passed through enough tubing, including the filter system, to ensure that at least $30 \mathrm{~min}$ had elapsed between liquid leaving the column and entering the gamma detector. The detector configuration allowed detection of ${ }^{137} \mathrm{Cs}$ levels of 5-10 counts above background. The feed level for the detector was about 7,000-12,000 counts/s; thus, the detection limit was about $0.05-0.15 \%$ of the feed. The counts for the area of the peak for ${ }^{137} \mathrm{Cs}$ were monitored, and the total counts for the selected counting times were recorded by the multichannel analyzer program for later printout.

After being loaded, the column was removed from the experimental system and from the cell to determine the quantity of ${ }^{137} \mathrm{Cs}$ loaded. The columns were counted using an Aptec intrinsic germanium detector and a Nuclear Data multichannel analyzer system. This system allowed the columns to be placed at distances up to several meters from the detector head for counting, which is necessary for materials that load a high level of radioactive cesium. The column product stream was collected in the fraction collector, and samples of these fractions were counted using a LKB Wallac 1282 Compugamma Universal Gamma Counter. The detection limit for this counter is about $0.1 \%$ of the feed concentration. Some sorbent eluent samples contained too much ${ }^{137} \mathrm{Cs}$ for this detector, so they were counted on the Aptec system at $30 \mathrm{~cm}$ from the detector head. Some of the fractions that contained solids, or were suspected to contain solids, could be sampled through $0.2-\mu \mathrm{m}$ syringe filters.

Regenerable ion-exchange resins in the columns could be treated with any desired eluents (usually $0.5 \mathrm{NHNO}_{3}$ ), regenerants (usually $2 \mathrm{~N} \mathrm{NaOH}$ ), or wash solutions; and the effluent could be monitored for removal of cesium from the module using the in-line detector. Eluent was added to the 1-L eluent tank from outside the cell so that any number of chemicals could be added at a given time. The resins could be eluted and regenerated in place to allow repeated cycling of the resin between cesium loading and removal; it could be removed for counting after loading and/or elution. Loaded columns could be drained, capped, and placed in storage containers for future testing, transport to other locations, or disposal.

The feed supernatant for the tests was obtained from MVST W-27 in April 1995. Approximately $56 \mathrm{~L}$ of the supernatant, enough for the first series of planned tests, was placed in storage vaults in Building 4501. Tank W-27, which contained supernatant at $\mathrm{pH} 7.2$ to 7.4 , had the lowest potassium and ${ }^{137} \mathrm{Cs}$ levels of the available tanks. Therefore, this supernatant could be more easily handled because of its lower gamma 
radiation level. (This was also a major reason for consideration for the CsRD tests.) In preparation for the cesium sorbent tests, the $\mathrm{pH}$ of the W-27 supernatant was adjusted to the levels in other tanks (about 12.5-13.3) by adding $\mathrm{NaOH}$ pellets. In order to simulate conditions at other DOE sites, the free hydroxide concentration was increased to $1 M$ and additional cesium was added, as cold cesium nitrate, for several tests.

For the CsRD qualification test of CST and W-29 supernatant, W-29 supernatant was withdrawn from tank W-29 after a 1-month equilibration following transfer of about 83,270 L (22,000 gal). The supernatant in tank W-27 had been adjusted by adding $3028 \mathrm{~L}$ ( 800 gal) of $50 \%$ caustic solution and mixing, followed by 2 weeks of settling before decanting to W-29. The CsRD uses W-29 as the supply tank for processing up to $94,625 \mathrm{~L}$ (25,000 gal) of supernatant through several columns of commercial CST. W-29 has previously been used as the feed tank for the Out-of-Tank Evaporation (OTE) test, as well as for various supernatant solidification campaigns, and thus contained a heel of liquid from those previous operations.

\section{EXPERIMENTAL PROCEDURES}

\subsection{ION-EXCHANGE MATERIALS USED}

In this study, we tested the most promising cesium sorbents as recommended by the ESP, based on previous batch tests used for screening many sorbents at Hanford, ${ }^{2,3}$ Sandia, ${ }^{2,4}$ Los Alamos, ${ }^{5}$ Savannah River, ${ }^{6}$ and Oak Ridge. ${ }^{7,8}$ SuperLig ${ }^{8} 644$ C, batch $3695-G M 1121$, is a polymer resin of the covalently bound SuperLig ${ }^{\circledR}$ macrocycle family of sequestering ligands from IBC Advanced Technologies (American Fork, Utah) and was supplied by Lane Bray, of the Pacific Northwest National Laboratory (PNNL). The RF resin developed at the Westinghouse Savannah River Company (WSRC) was made in several batches by Boulder Scientific (Mead, Colorado). One batch was supplied in the potassium form directly by Jane Bibler of WSRC (i.e., the Bibler batch). A second batch was transferred from Jane Bibler to R. R. Brunson and W. D. Bond of the REDC at ORNL (i.e., the REDC batch). ${ }^{9}$ A third batch of RF resin was furnished by AEA from batch BSC-187 supplied by Jane Bibler to AEA (i.e., the AEA batch). The engineered forms

of the crystalline silicotitanate developed by Sandia National Laboratories/Texas A\&M were produced and 
supplied by UOP as IONSIV ${ }^{\circledR}$ IE-911, lots $07398-38 B$ and 999096810001 . The CST used in the CsRD qualification test was purchased by ORNL from UOP as IONSIV ${ }^{\circledR}$ IE-911, lot 999096810003 . It was pretreated by the CsRD personnel following UOP directions and delivered in slurry form for the tests.

\subsection{PREPARATION OF SUPERNATANT FOR TESTS}

Use of the MVST W-27 supernatant received from ORNL Waste Operations in April 1995 required $\mathrm{pH}$ adjustment prior to the tests on the ion-exchange materials being considered for the alkaline supernatant tank wastes at ORNL, Hanford, and SRS. The CsRD was also planning to perform its demonstration at a pH of 12.5-13.0. The W-27 supernatant had a pH of 7.2, while the $\mathrm{pH}$ of the supernatants in the other MVST tanks varied from 7 to $>13$. To increase the $\mathrm{pH}$, about $0.5-0.7 \mathrm{~mol}$ of solid $\mathrm{NaOH}$ had to be added per liter of supernatant. Each container of supernatant contained approximately $2 \mathrm{gal}$, or $7.5 \mathrm{~L}$, so that a total of $140-220 \mathrm{~g}$ of $\mathrm{NaOH}$, or about $28 \mathrm{~g} / \mathrm{L}$, was required to complete the adjustment to the higher $\mathrm{pH}$. Adjusting the $\mathrm{pH}$ with $\mathrm{NaOH}$ added $0.5-0.7 \mathrm{~mol}$ per liter of sodium to the sodium concentration of the supernatant. The analyses of the W-27 supernatant sample taken in December 1994 (Request 941219-087) and of a sample of the supernatant fed to the ion-exchange column after the $\mathrm{pH}$ adjustment and filtration in cell $\mathrm{C}$ (Request 950619-053) are shown in Table 1. Additional $\mathrm{NaOH}$ and cold cesium, as cesium nitrate, were added to the supernatant to simulate some of the supernatants at Hanford. The analysis of the feed after adjustment to $\mathrm{pH} 14$ and addition of cold cesium (Request 960321-076) is listed in Table 2.

\subsubsection{Preparation of Initial W-27 Supernatant}

The supernatant was prepared by adding $\mathrm{NaOH}$ pellets to keep dilution to a minimum. The caustic was added to achieve a $\mathrm{pH}$ of 13.3 , as calculated based on the free hydroxide concentration determined by titration to the phenolphthalein end point. As the caustic was added to the yellow supernatant, a fine, slowsettling precipitate began to form. The feed for the $\mathrm{pH} 14$ experiments was adjusted in the same manner, but additional $\mathrm{NaOH}$ pellets were added to obtain the $1 N$ hydroxide concentration equivalent to $\mathrm{pH} 14$. A solution of cesium nitrate was prepared, and a small aliquot was added to give a total cesium concentration approximately ten times the original level present in the W-27 tank. 
Table 1. Analyses of the MVST W-27 supernatant (pH 13) ${ }^{a}$

\begin{tabular}{|c|c|c|c|c|c|}
\hline \multicolumn{3}{|c|}{ Radiochemical, $\mathrm{Bq} / \mathrm{mL}$} & \multicolumn{2}{|l|}{ Anion, mg/L } & \multirow{2}{*}{$\frac{\mathrm{mol} / \mathrm{L}}{3.60 \mathrm{E}-03}$} \\
\hline${ }^{60} \mathrm{Co}$ & 680 & & $\mathrm{Br}$ & 288 & \\
\hline${ }^{137} \mathrm{Cs}$ & 320,000 & & $\mathrm{Cl}$ & 3,180 & $8.97 \mathrm{E}-02$ \\
\hline${ }^{134} \mathrm{Cs}$ & 1,400 & & $\mathrm{~F}$ & $<7.5$ & \\
\hline${ }^{90} \mathrm{Sr}$ & 65,000 & & $\mathrm{NO}_{2}$ & & \\
\hline${ }^{99} \mathrm{Tc}$ & 270 & & $\mathrm{NO}_{3}$ & 322,000 & $5.19 E+00$ \\
\hline Gross alpha & 0.9 & & $\mathrm{PO}_{4}$ & $<0$ & \\
\hline Gross beta & 21,000 & & $\mathrm{SO}_{4}$ & 1,540 & $1.60 \mathrm{E}-02$ \\
\hline Density & $1.27 \mathrm{~g} / \mathrm{L}$ & & $\mathrm{OH}$ & & $7.08 \mathrm{E}-02$ \\
\hline RCRA metal (mg & & & Cation, $\mathrm{mg} / \mathrm{L}$ & & $\mathrm{mol} / \mathrm{L}$ \\
\hline $\mathrm{Ag}$ & 0.055 & & $\mathrm{Al}$ & 0.847 & $3.14 \mathrm{E}-05$ \\
\hline As & 0.0089 & & $\mathrm{Be}$ & $<0.0022$ & \\
\hline $\mathrm{Ba}$ & 8.04 & & $\mathrm{Ca}$ & 89.1 & $2.22 \mathrm{E}-03$ \\
\hline $\mathrm{Cd}$ & 0.22 & & Co & $<0.12$ & \\
\hline $\mathrm{Cr}$ & 2.96 & & $\mathrm{Cs}^{b}$ & 0.935 & $7.04 \mathrm{E}-06$ \\
\hline $\mathrm{Hg}$ & 0.09 & & $\mathrm{Cu}$ & $<0.0319$ & \\
\hline $\mathrm{Pb}$ & 0.0092 & & $\mathrm{Fe}$ & $<0.0352$ & \\
\hline \multirow[t]{4}{*}{$\mathrm{Se}$} & $<0.005$ & & $\mathrm{~K}$ & 10,300 & $2.63 \mathrm{E}-01$ \\
\hline & & & $\mathrm{Mg}$ & $<298$ & \\
\hline & Electrolyte & Balance & $\mathrm{Mn}$ & $<.0055$ & \\
\hline & Anion & Cation & $\mathrm{Na}$ & 113,000 & $4.93 \mathrm{E}+00$ \\
\hline Totals & 5.390 & 5.198 & $\mathrm{Ni}$ & 1.22 & $2.08 \mathrm{E}-05$ \\
\hline \multirow[t]{9}{*}{ Difference } & 0.191 & & $\mathrm{Rb}$ & 1.1 & 1.29E-05 \\
\hline & & & $\mathrm{Sb}$ & $<0.218$ & \\
\hline & & & $\mathrm{Si}$ & & \\
\hline & & & $\mathrm{Sr}$ & & \\
\hline & & & Th & $<0.440$ & \\
\hline & & & $\mathrm{Tl}$ & $<0.005$ & \\
\hline & & & $\mathrm{U}$ & $<1.0$ & \\
\hline & & & $\mathrm{V}$ & $<0.0561$ & \\
\hline & & & $\mathrm{Zn}$ & 0.473 & $7.23 \mathrm{E}-06$ \\
\hline
\end{tabular}

${ }^{a}$ Request No. 950619-053; analyses performed July 1995; Na/Cs ratio $=701,451 ; \mathrm{K} / \mathrm{Cs}$ ratio $=37,446$.

${ }^{b}$ Value for the total cesium for the 7/95 sample was determined by removing all Cs, eluting with acid, and then analyzing that sample. 
Table 2. Analyses of the MVST W-27 supernatant ( $\mathrm{pH} 14$ and added cold cesium) ${ }^{a}$

\begin{tabular}{|c|c|c|c|c|c|}
\hline \multicolumn{3}{|c|}{ Radiochemical, $\mathrm{Bq} / \mathrm{mL}$} & \multicolumn{2}{|l|}{ Anion, $\mathrm{mg} / \mathrm{L}$} & \multirow[t]{2}{*}{$\mathrm{mol} / \mathrm{L}$} \\
\hline${ }^{60} \mathrm{Co}$ & 330 & & $\mathrm{Br}$ & $<50.0$ & \\
\hline${ }^{137} \mathrm{Cs}$ & 340,000 & & $\mathrm{Cl}$ & 2,960 & $8.35 \mathrm{E}-02$ \\
\hline${ }^{134} \mathrm{Cs}$ & 920 & & $\mathrm{~F}$ & $<5.00$ & \\
\hline${ }^{90} \mathrm{Sr}$ & 31,000 & & $\mathrm{NO}_{2}$ & 2,720 & $5.91 \mathrm{E}-02$ \\
\hline${ }^{99} \mathrm{Tc}$ & & & $\mathrm{NO}_{3}$ & 298,000 & $4.81 \mathrm{E}+00$ \\
\hline Gross alpha & 0.4 & & $\mathrm{PO}_{4}$ & $<10.0$ & \\
\hline \multirow[t]{2}{*}{ Gross beta } & 430,000 & & $\mathrm{SO}_{4}$ & 1,380 & $8.63 E-03$ \\
\hline & & & $\mathrm{OH}$ & 1.04 & $1.04 \mathrm{E}+00$ \\
\hline RCRA metal, mg/L & & $\mathrm{mol} / \mathrm{L}$ & Cation, $\mathrm{mg} / \mathrm{L}$ & & $\mathrm{mol} / \mathrm{L}$ \\
\hline $\mathrm{Ag}$ & $<0.0645$ & & $\mathrm{Al}$ & $<0.146$ & \\
\hline As & $<0.0250$ & & $\mathrm{Be}$ & $<0.008$ & \\
\hline $\mathrm{Ba}$ & 5.61 & $4.09 \mathrm{E}-05$ & $\mathrm{Ca}$ & 3.1 & $7.75 \mathrm{E}-05$ \\
\hline $\mathrm{Cd}$ & $<0.11$ & & Co & $<0.0720$ & \\
\hline $\mathrm{Cr}$ & 3.49 & $6.71 \mathrm{E}-05$ & $\mathrm{Cs}$ & 9.95 & $7.48 \mathrm{E}-05$ \\
\hline $\mathrm{Hg}$ & 0.117 & $5.83 \mathrm{E}-07$ & $\mathrm{Cu}$ & 0.15 & $2.36 \mathrm{E}-06$ \\
\hline $\mathrm{Pb}$ & $<10$ & & $\mathrm{Fe}$ & $<0.017$ & \\
\hline \multirow[t]{2}{*}{$\mathrm{Se}$} & $<0.0250$ & & $\mathrm{~K}$ & 12,000 & $3.07 \mathrm{E}-01$ \\
\hline & & & $\mathrm{Mg}$ & $<0.0985$ & \\
\hline \multicolumn{3}{|l|}{ Other } & Mn & $<0.008$ & \\
\hline TIC & $300 \mathrm{mg} / \mathrm{L}$ & & $\mathrm{Na}$ & 127,000 & $5.52 E+00$ \\
\hline TOC & $390 \mathrm{mg} / \mathrm{L}$ & & $\mathrm{Ni}$ & 0.73 & $1.24 \mathrm{E}-05$ \\
\hline TOT C & $690 \mathrm{mg} / \mathrm{L}$ & & $\mathrm{Rb}$ & 2.06 & $2.41 \mathrm{E}-05$ \\
\hline Density & $1.3 \mathrm{~g} / \mathrm{L}$ & & $\mathrm{Sb}$ & $<1.10$ & \\
\hline \multirow[t]{4}{*}{$\mathrm{pH}$} & 14.017 & & & & \\
\hline & & & $\mathrm{Si}$ & 29.3 & $1.04 \mathrm{E}-03$ \\
\hline & Electrolyte & Balance & $\mathrm{S} r$ & 26.3 & $3.00 \mathrm{E}-04$ \\
\hline & Anion & Cation & Th & $<0.243$ & \\
\hline Totals & 6.006 & 5.832 & $\mathrm{Tl}$ & $<0.969$ & \\
\hline \multirow[t]{3}{*}{ Difference } & 0.174 & & $\mathrm{U}$ & 0.485 & $2.04 \mathrm{E}-06$ \\
\hline & & & V & $<0.0205$ & \\
\hline & & & $\mathrm{Zn}$ & $<0.148$ & \\
\hline
\end{tabular}

Request No. 960317-076; analysis performed July 1995; Na/Cs ratio = 12,764; K/Cs ratio = 1,206. 
Analyses of the feed sample (obtained in April 1995) after $\mathrm{pH}$ adjustment to 13.3, followed by settling and filtration, showed $3.2 \times 10^{5} \mathrm{~Bq}{ }^{137} \mathrm{Cs} / \mathrm{mL}, 7.1 \times 10^{-6} \mathrm{M}$ total Cs (measured by removing all Cs from a sample and analyzing for total cesium and ${ }^{137} \mathrm{Cs}$ ), $0.26 \mathrm{MK}$, and $4.7 \mathrm{MNa}$. The total $\mathrm{Cs}$ in the $\mathrm{W}-27$ supernatant was about 2.7 times that expected, based on the ${ }^{137} \mathrm{Cs}$ detected $\left(2.06 \times 10^{-6} \mathrm{M}\right)$. An estimate of the total Cs can be taken as about three and one-third times the amount of ${ }^{137} \mathrm{Cs}$ present, based on the total decay time until measurement. ${ }^{10}$ It should be noted that the ${ }^{137} \mathrm{Cs}$ level in the MVST supernatants, ${ }^{11}$ some of which have cooled for 15 to 20 years, is one to two orders of magnitude less than that present in the Hanford tank supernatants. ${ }^{12,13}$ The sample of supernatant adjusted to $1 N$ hydroxide (pH 14) was analyzed to contain $3.4 \times 10^{5} \mathrm{~Bq}{ }^{137} \mathrm{Cs} / \mathrm{mL}, 1.0 \times 10^{-5} \mathrm{M}$ total $\mathrm{Cs}\left(7.5 \times 10^{-5} \mathrm{M}\right.$ when nonradioactive $\mathrm{CsNO}_{3}$ was added), $0.31 \mathrm{MK}$, and $5.52 \mathrm{MNa}$ without added Cs.

The Cs level in the high-Cs feed (W-27 supernatant with cold Cs added) is approximately comparable to the values given for Hanford tanks 101-SY $\left(4.7 \times 10^{-5} \mathrm{M}\right)$ and 103-SY $\left(5.4 \times 10^{-5} \mathrm{M}\right)$ and also to the DSSF simulant $\left(1.1 \times 10^{-4} M\right)$. This level is about 7-9 times the value for W-27 as determined by analysis $\left(7 \times 10^{-6}\right.$ to $\left.1 \times 10^{-5} \mathrm{M}\right)$. The composition has a Na/Cs molar ratio of about $7.4 \times 10^{4}$ and a $\mathrm{Na} / \mathrm{K}$ ratio of 18 after the addition of sodium hydroxide to increase the $\mathrm{pH}$ to 14 .

\subsubsection{Selection of Supernatant for CsRD Tests}

Several batch contact tests were performed in order to prepare for the CsRD tests using CST. The ion-exchange material used for these tests was UOP IONSIV IE-911 CST lot 999096810001 . The tests were designed to help select the supernatant to be used in the CsRD. The supernatant (from W-27 or W-31) had to be transferred to the feed tank for operation of the demonstration (i.e., tank W-29), which contained a heel of liquid and a layer of solids from previous operations using the tank. (This tank was also the feed tank for the solidification campaigns.) Tank W-29 was last used as the feed tank for the Out-ofTank Evaporation (OTE) test during FY 1996, and a heel of unknown volume (because the sludge depth cannot be measured) was present in W-29 following that test.

Tank W-29 was estimated to contain approximately 11,000 gal of liquid above a sludge layer, based on results obtained from S. DePaoli. ${ }^{14}$ DePaoli used ${ }^{137} \mathrm{Cs}$ concentrations for W-24, W-29 prior to W-24 addition, and W-29 after OTE to back-calculate the volume of W-29 supernatant that it had taken to change the cesium concentration in the W-24/W-29 mixture previously contained in W-29. The concentration in 
$\mathrm{W}-27$ was $3.3 \times 10^{5} \mathrm{~Bq} / \mathrm{mL}$. By calculation, the W-27/W-29 mixture should produce a Cs concentration of $5.1 \times 10^{5} \mathrm{~Bq} / \mathrm{mL}$, and the W-31/W-29 mixture should produce a Cs concentration of $6.1 \times 10^{5} \mathrm{~Bq} / \mathrm{mL}$.

Based on that analysis, ${ }^{14}$ the estimate of the amount of supernatant that would be pumped into the W-29 tank for use in the CsRD was approximately 22,000 gal, giving a level of about $90 \%$ of the total available volume in the 50,000-gal tank. The CsRD would use up to 25,000 gal of the W-29 for the test. Based on these estimates, a ratio of two parts W-27 or W-31 to one part W-29 was selected to produce feed material for the batch tests with CST. The two tanks that can be used in the CsRD are W-27 and W-31. Tank W-27 supernatant has been well characterized in the tests conducted to date. It has a fairly low ${ }^{137} \mathrm{Cs}$ concentration, as well as low concentrations of most RCRA metals. Tank W-31 is supposed to have a higher ${ }^{137} \mathrm{Cs}$ concentration, an elevated chromium concentration ( $\sim 10 \mathrm{ppm}$ chromium; $5 \mathrm{ppm}$ is the RCRA limit), and a $\mathrm{pH}$ of $\sim 11.9$, as compared with $\mathrm{W}-27$ at a $\mathrm{pH}$ of $\sim 7.4$, but would not require $\mathrm{pH}$ adjustment. Tank W-27 also contains more cold cesium than the fission product yield alone would predict; the values of total cesium in W-29 and W-31 are not known accurately at this time.

\subsubsection{CsRD Supernatant Tests-Analysis of Supernatant}

The supernatant from MVST W-29 used for the batch test series was obtained from the Bldg. 2026 Analytical Services samples that had been sent for analysis from the OTE test performed in MarchApril 1996. Six bottles of the evaporator feed were sampled (7-8 $\mathrm{mL}$ per bottle), resulting in a composite of approximately $45 \mathrm{~mL}$. This composite was transferred to Bldg. 4501 for use in the batch-contact tests.

The approximate $\mathrm{pH}$ (operational definition for comparison) of the W-29 composite was checked by titration to the phenolphthalein end point to be about $13.44(1 \mathrm{~mL}$ of W-29 required $2.80 \mathrm{~mL}$ of $0.1 \mathrm{~N} \mathrm{HCl}$ for neutralization). To make the feed mixtures for the batch tests, $20 \mathrm{~mL}$ of W-29 sample was mixed with $40 \mathrm{~mL}$ of W-27 sample, and $20 \mathrm{~mL}$ of W-29 was mixed with $40 \mathrm{~mL}$ of the W-31 sample. The W-27 and W-31 samples were archival samples that had been obtained in December 1994 and stored in Bldg. 4501 since that time. For comparison, a $60-\mathrm{mL}$ sample of the $\mathrm{W}-27$ was also submitted to the same set of batch tests. 


\subsubsection{CsRD Supernatant Tests-Results of Mixing Tests}

The $\mathrm{pH}$ levels of the batch feeds were determined after mixing (the W-27 feed was adjusted by adding $1.431 \mathrm{~g}$ of $\mathrm{NaOH}$ pellets and then mixing). The $\mathrm{pH}$ of the W-31/W-29 mixture titrated to 13.08 , the W-29/W-27 mixture to 11.20 , and the W-27 feed to 12.95 . The W-29/W-27 mixture was adjusted, first, by adding $0.204 \mathrm{~g}$ of $\mathrm{NaOH}$. A recheck of the $\mathrm{pH}$ gave a value of 12.30 , so an additional $0.191 \mathrm{~g}$ of $\mathrm{NaOH}$ was added, resulting in a final $\mathrm{pH}$ of 12.76 . These values are consistent with estimates based on the mixing of the supernatants using the $\mathrm{pH},{ }^{137} \mathrm{Cs},{ }^{134} \mathrm{Cs}$, and density analyses for the samples taken in December 1994 . (The W-29 analyses were based on the W-24 supernatant, which was later transferred to W-29.)

The batch tests were designed to give an estimate of the performance of the UOP IONSIV IE-911 CST commercial material with each of the two tank mixes as well as a comparison with the W-27 used in the sorbent selection tests. A series of four liquid/solid ratios was used to cover a 10:1 to 1000:1 range of supernatant to CST (10:1, 100:1, 500:1, and 1000:1, based on the wet mass of caustic equilibrated CST). The tests were set up as $\sim 18$-h batch shake experiments with no intermediate sampling. The results are based on the amount of ${ }^{137} \mathrm{Cs}$ removed from the $5-\mathrm{mL}$ sample during that time. The sorbent was also rinsed three times with water after the supernatant had been removed, dried in air, and then counted to try and determine the specific activity of the ${ }^{137} \mathrm{Cs}$ loaded at the various liquid/solid ratios.

When the W-29 and W-31 supernatants were mixed, no precipitation occurred either initially or after standing overnight. When W-29 and W-27 were mixed, a precipitate consisting of a white, fluffy, slowsettling material formed immediately. When $\mathrm{NaOH}$ was added to the $\mathrm{W}-27$ sample, immediate precipitation also occurred, visually similar but with considerably more volume and slower settling than the W-27/W-29 mixture. After overnight settling, the W-27/W-29 mixture had a total liquid height of $25 \mathrm{~mm}$ and a sludge layer height of $5 \mathrm{~mm}$. The W-27 sample had a total height of $26 \mathrm{~mm}$ and a sludge layer of $9 \mathrm{~mm}$. After the additional $0.4 \mathrm{~g}$ of $\mathrm{NaOH}$ had been added for $\mathrm{pH}$ adjustment in the W-27/W-29 mixture, the solids were still fluffy but settled rather quickly ( 5 to 10 min produced a clear layer more than half of the total depth).

The two feeds with solids were filtered to yield a clear liquid for the batch tests; the filtrate obtained using $0.45-\mu \mathrm{m}$ syringe filters was $\sim 45 \mathrm{~mL}$ in each case. A $0.5-\mathrm{mL}$ sample was removed from each feed bottle for analysis of the ${ }^{137} \mathrm{Cs}$ activity by gamma spectroscopy. The results for radioactivity and density are shown in Table 3. 
12

Table 3. Results of supernatant mixing test

\begin{tabular}{|c|c|c|c|c|c|c|}
\hline Supernatant & $\begin{array}{c}\text { Hydroxide } \\
\text { (M) }\end{array}$ & $\mathrm{pH}$ & $\begin{array}{c}{ }^{137} \mathrm{Cs} \\
(\mu \mathrm{Ci} / \mathrm{mL})\end{array}$ & $\begin{array}{c}{ }^{134} \mathrm{Cs} \\
(\mu \mathrm{Ci} / \mathrm{mL})\end{array}$ & $\underset{{ }^{137} \mathrm{Cs} /{ }^{133^{4}} \mathrm{Cs}}{\text { Ratio }}$ & $\begin{array}{l}\text { Density } \\
\left(\mathrm{g} / \mathrm{cm}^{3}\right)\end{array}$ \\
\hline $\mathrm{W}-27^{a}$ & 0.089 & 12.95 & 10.07 & 0.0435 & 132 & 1.268 \\
\hline$W-27 / W-29$ & 0.057 & 12.76 & 15.53 & 0.376 & 41.3 & 1.240 \\
\hline$W-31 / W-29$ & 0.121 & 13.08 & 18.046 & 0.536 & 33.7 & 1.238 \\
\hline
\end{tabular}

The CST material was initially prepared by placing $10 \mathrm{~mL}$ (tapped volume) with a mass of $10.335 \mathrm{~g}$ in a flow-through column and treating it with $2 \mathrm{MNaOH}$ solution in a preconditioning step before the batch tests. The CST IE-911 -0001 batch has been shown to have a high ability to reduce the $\mathrm{pH}$ of a solution, and the cesium removal ability is very $\mathrm{pH}$ dependent in the 12-13.5 range, so it is very important to prevent $\mathrm{pH}$ changes in the test solution that would give inaccurate data upon which to base column performance. The treatment consisted of wetting the CST with $50 \mathrm{~mL}$ of the caustic solution in a slow upflow mode. The solution was left to stand for $30 \mathrm{~min}$, after which another $10-\mathrm{mL}$ volume was pumped into the column. The CST-solution mixture was allowed to stand overnight, and then $40 \mathrm{~mL}$ of solution was pumped through at a rate to fluidize the bed and carry out fines. The bed was subsequently allowed to settle for $30 \mathrm{~min}$. Finally, an additional $10 \mathrm{~mL}$ was pumped through at low rates and allowed to stand for $1 \mathrm{~h}$. The CST was then transferred to a $15-\mathrm{mL}$ centrifuge cone, still in contact with $2 \mathrm{MNaOH}$, and prepared for the batch tests by adding the desired mass (measured wet with $\mathrm{NaOH}$ solution) into tared centrifuge cones. Additional samples with the same ratios of wet CST material as that added to the test cones were also dried to determine the dry weight (dried in $2 M$ caustic) added to the supernatant.

\subsubsection{CsRD Supernatant Tests-Results of Batch-Contact Tests}

The test cones with supernatant and CST were placed on a rocking contacter for the prescribed time. Two of the liquids were also placed in cones without CST to check for supernatant-tube interaction. When contacting was complete, the tubes were removed and the liquid in each tube was withdrawn and placed into new cones. A sample of the liquid in each cone was then filtered and placed in a new cone. Finally, 
a sample of the filtered liquid was taken to determine, by gamma spectroscopy, the amount of ${ }^{137} \mathrm{Cs}$ remaining in the solution. Two samples of each feed liquid were withdrawn as well, for the initial concentration baseline. Samples of the unfiltered liquid from three of the cones containing the CST were also taken to determine whether any of the CST had decomposed and become a part of the liquid stream during the sampling process. The solid CSTs left in the tubes were washed three times with water and then allowed to air dry before weighing and counting.

The results for the determination of the densities of the feed materials are the averages of five samples of $5 \mathrm{~mL}$ each. The densities are as follows: W-31/W-29 $=1.2380, \mathrm{~W}-27 / \mathrm{W}-29=1.2401$, and $\mathrm{W}-27=1.2681$. This is in good agreement with the predicted densities based on the December 1994 analyses ${ }^{15}$ of MVST analytical samples, using the analytical results from W-24 for W-29 (W-24 was transferred to W-29 during this period).

The counting results for the samples of liquid removed from each of the tubes containing CSTs are given in Fig. 2. The graph shows the calculated solid/liquid ratio and the $\mathrm{D}$ value for removal of ${ }^{137} \mathrm{Cs}$. It also shows the relationship of the results to each other and indicates that if W-31/W-29 feed were used, significantly more ${ }^{137} \mathrm{Cs}$ would be loaded as compared with using W-27/W-29. This would cause a much higher radiation field for the column for the same amount of supernatant passed through the column as compared with W-27/W-29 feed. Therefore, W-27 was chosen to be added to W-29 as offering the most flexibility and safety in experimental conditions during the CsRD operations.

\subsubsection{CsRD Supernatant Tests-Preparation of Supernatant}

Based on the results of these tests, it was decided that W-27 would be used for the CsRD tests after being pumped to tank W-29. For use in the CsRD tests, the W-27 supernatant needed to have a final $\mathrm{pH}$ of 12.5-13.0 after it had been mixed with the supernatant remaining in tank W-29 after previous operations. Therefore, the $\mathrm{pH}$ of the supernatant in W-27 had to be increased to approximately 11.9-12.0, assuming that the desired volume ratios were 2 parts W-27 to 1 part W-29. This step theoretically required approximately the amount of caustic needed to precipitate the calcium and magnesium from solution. Since the W-27 supernatant was about $0.26 \mathrm{M}$ in $\mathrm{Ca}$ and $0.0272 \mathrm{M}$ in $\mathrm{Mg}$, approximately $0.575 \mathrm{~mol}$ of hydroxide ion per liter of supernatant would be required $(0.574 \mathrm{~mol}$ to precipitate and $0.01 \mathrm{~mol}$ to change the $\mathrm{pH})$. 


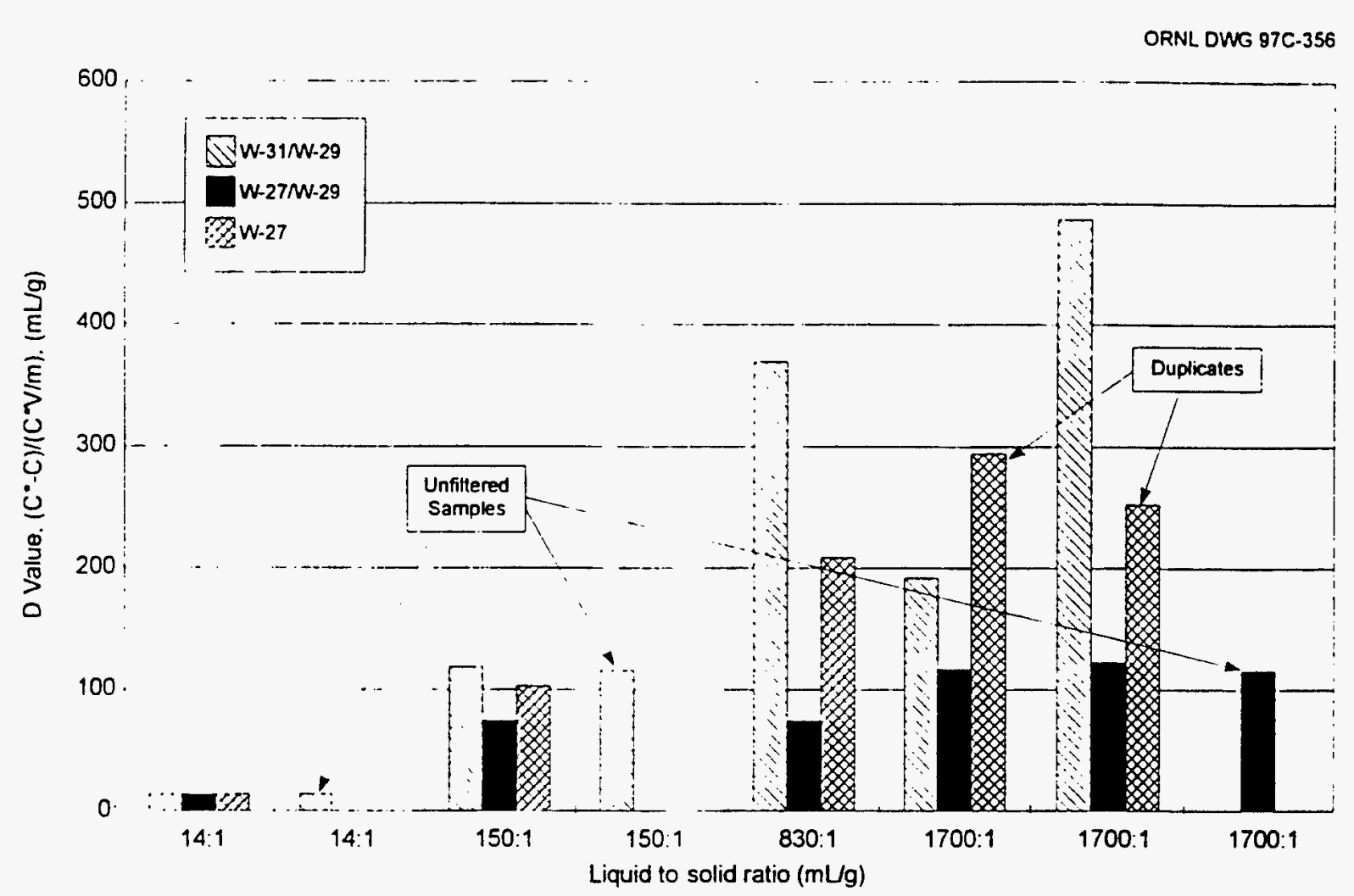

Fig. 2. Batch contacts of IE-911 with proposed supernatants for the CsRD.

This step required $23 \mathrm{~g}$ of $\mathrm{NaOH}$ per liter of supernatant, or $29.6 \mathrm{~mL} 50 \% \mathrm{NaOH}$ solution (approximately $19.4 \mathrm{~N}$ ) per liter of supernatant. Assuming a supernatant volume of $102,200 \mathrm{~L}$ (27,000 gal) in W-27, then $58,762 \mathrm{~mol}$ of hydroxide would be required; this would be equivalent to $3029 \mathrm{~L}$ of $50 \% \mathrm{NaOH}$ solution ( $800 \mathrm{gal}$ ) required to adjust the $\mathrm{pH}$ of all of the supernatant in the tank before pumping.

To verify this assumption, samples of the W-27 supernatant were mixed with varying amounts of $50 \%$ $\mathrm{NaOH}$ solution and allowed to settle. The $\mathrm{pH}$ levels of the W-27 supernatant and $\mathrm{NaOH}$ solutions were then determined. The results are shown in Table 4.

After the 800 gal of $50 \%$ caustic had been added to W-27 on June 26,1996 , the tank was allowed to settle for 2 weeks and then the desired volume of supernatant was pumped to W-29 on July 11, 1996. The latter was allowed to settle for 30 days before a sample was withdrawn on August 8, 1996, for testing. That sample was delivered to Building 4501 on August 9, removed from the carrier drum, subsampled, placed in the hot cell, and connected to the transfer system for use in the flow studies on the CST column. 
Table 4. Test of proposed $\mathrm{pH}$ adjustment of W-27 supernatant

\begin{tabular}{|c|c|c|c|c|c|c|c|c|c|c|c|c|}
\hline \multirow[b]{2}{*}{ Tube ${ }^{a}$} & \multirow{2}{*}{$\begin{array}{l}\text { Caustic } \\
\text { added, } \\
(\mathrm{mL})^{b, c}\end{array}$} & \multirow{2}{*}{$\begin{array}{c}\mathrm{NaOH} \\
\text { (mol/L) } \\
\text { added } \\
\text { to } \mathrm{W}-27\end{array}$} & \multirow{2}{*}{$\begin{array}{c}\text { Gal } \\
50 \% \text { to } \\
27,000 \\
\text { gal }\end{array}$} & \multirow{2}{*}{$\begin{array}{l}\text { Tube } \\
\text { tot. vol. } \\
\text { (mL) }\end{array}$} & \multicolumn{4}{|c|}{$\begin{array}{c}\text { Volume of precipitate } \\
\text { (mL) after }\end{array}$} & \multirow{2}{*}{$\begin{array}{c}{[\mathrm{OH}]} \\
\text { of } \\
\text { solution }\end{array}$} & \multirow{2}{*}{$\begin{array}{c}24-\mathrm{h} \\
\mathrm{pH} \text { of } \\
\text { solution }\end{array}$} & \multirow{2}{*}{$\begin{array}{c}\text { 6-d } \\
\text { pH of } \\
\text { solution }\end{array}$} & \multirow{2}{*}{$\begin{array}{c}\text { Vol. of prec. } \\
\text { in } 270,000 \\
\text { gal of super, } \\
\text { gal }\end{array}$} \\
\hline & & & & & $24 \mathrm{~h}$ & $48 \mathrm{~h}$ & $5 d$ & $6 d$ & & & & \\
\hline 1 & 0.35 & 0.6447 & 945 & 10.8 & 3.5 & 2.8 & 2.3 & 2.2 & 0.121 & 13.0828 & & 5750 \\
\hline 2 & 0.35 & 0.6447 & 945 & 10.8 & 3.5 & 2.8 & 2.2 & 2.1 & 0.139 & . & 13.143 & 5500 \\
\hline 3 & 0.30 & 0.5526 & 810 & 10.6 & 2.8 & 2.3 & 2.1 & 2.0 & 0.068 & 12.8325 & & 5349 \\
\hline 4 & 0.30 & 0.5526 & 810 & 10.6 & 2.7 & 2.3 & 1.9 & 1.9 & 0.070 & & 12.845 & 4840 \\
\hline 5 & 0.25 & 0.4605 & 675 & 10.5 & 2.5 & 2.2 & 1.9 & 1.8 & 0.038 & 12.5798 & & 4886 \\
\hline 6 & 0.25 & 0.4605 & 675 & 10.6 & 2.8 & 2.6 & 2.3 & 2.2 & 0.038 & & 12.580 & 5858 \\
\hline 7 & 0.20 & 0.3684 & 540 & 10.5 & 2.5 & 2.3 & 2.0 & 1.9 & 0.030 & 12.4771 & & 5143 \\
\hline 8 & 0.20 & 0.3684 & 540 & 10.5 & 2.65 & 2.3 & 2.1 & 2.0 & 0.028 & & 12.447 & 5400 \\
\hline 9 & 0.15 & 0.2763 & 405 & 10.5 & 2.5 & 2.3 & 2.0 & 1.8 & 0.025 & 12.3979 & & 5143 \\
\hline 10 & 0.15 & 0.2763 & 405 & 10.5 & 2.7 & 2.4 & 2.1 & 2.0 & 0.025 & & 12.398 & 5400 \\
\hline 11 & \multicolumn{2}{|c|}{$25 \mathrm{~mL} \mathrm{~W}-29+5 \mathrm{~mL} \# 10$} & & 7.5 & $0.2+0.8$ & & & & 0.028 & 12.447 & & \\
\hline
\end{tabular}

${ }^{a}$ Sample tubes consisted of $15-\mathrm{mL}$ polypropylene graduated centrifuge tubes. They were prepared by pipetting $10 \mathrm{~mL}$ of W-27 sample (December 1994) in four 25-mL batches into each of 10 tubes.

Duplicate additions of $50 \%$ caustic were made in the volumes of $0.35,0.30,0.25,0.20$, and $0.15 \mathrm{~mL}$ to cover the possible range of caustic addition.

Titration of the caustic used in the $\mathrm{pH}$ adjustment tests required $138.15 \mathrm{~mL}$ of $0.02 \mathrm{~N} \mathrm{HCl}$ to titrate $0.15 \mathrm{~mL}$ to phenolphthalein end point $\mathrm{NaOH}[\mathrm{Cl}-1]=18.42 \mathrm{~mol} / \mathrm{L}$.

The sample of the W-29 feed was sent to the Chemical and Analytical Sciences Division (CASD) for chemical and radiological analyses. The results of these analyses are given in Table 5.

\subsection{PREPARATION OF COLUMNS}

The 1.5-cm-ID x 15-cm-tall glass columns, with polypropylene end fixtures for ion-exchange sorbents, were prepared for use by, first, attaching a dimensional tape to the outside surface of the column to allow the observation of the bed depth and liquid level from outside the cell. The sorbent to be used was then treated in a preparation column by the sorbent-specific procedure recommended by the provider or manufacturer. The measured volume was next added to the column, and the depth of the bed was measured after settling and removal of all air bubbles. Air bubbles were removed by flowing liquid up through the bed to partially fluidize it and allow the bubbles to rise and escape. A few bubbles had to be removed by 
Table 5. Analysis of W-29 supernatant used in the CsRD qualification test ${ }^{a}$

\begin{tabular}{|c|c|c|c|c|c|}
\hline \multicolumn{3}{|c|}{ Radioactive analyses, $\mathrm{Bq} / \mathrm{mL}$} & \multicolumn{3}{|l|}{ Anion, $\mu g / L$} \\
\hline${ }^{60} \mathrm{Co}$ & 500 & $+/ .50$ & $\mathrm{Cl}$ & 3,050 & $+/-300$ \\
\hline${ }^{134} \mathrm{Cs}$ & 7,600 & $+/-200$ & $\mathrm{NO}_{2}$ & 20,400 & $+1-2,000$ \\
\hline${ }^{137} \mathrm{Cs}$ & 460,000 & $+/-1 \mathrm{E} 4$ & $\mathrm{NO}_{3}$ & 250,000 & $+/-35,000$ \\
\hline Gross alpha & 30 & $+/-34$ & $\mathrm{OH}$ & 4,500 & Calculated \\
\hline Gross beta & 550,000 & $+/-1 \mathrm{E} 4$ & $\mathrm{SO}_{4}$ & 15,506 & $+/-165$ \\
\hline${ }^{239} \mathrm{Pu}$ & $<1.2$ & & & & \\
\hline${ }^{200} \mathrm{Pu}$ decay & $<4.2$ & & Cation, $\mu \mathrm{g} / \mathrm{L}$ & & \\
\hline Total radio-Sr & 4,100 & $+1-300$ & $\mathrm{Al}$ & 4.17 & $+/-0.12$ \\
\hline \multirow[t]{2}{*}{${ }^{2} \mathrm{Tc}$ decay } & 342 & $+1-68$ & $\mathrm{Be}$ & $<5 \mathrm{E}-3$ & \\
\hline & & & $\mathrm{Ca}$ & 1.42 & $+/-0.05$ \\
\hline \multicolumn{3}{|c|}{ RCRA metals, $\mu \mathrm{g} / \mathrm{mL}$} & co & $<9.5 \mathrm{E}-2$ & \\
\hline $\mathrm{Ag}(5 \mathrm{mg} / \mathrm{L})$ & $<0.1$ & & Cs & 0.58 & $+/-0.116$ \\
\hline As $(5 \mathrm{mg} / \mathrm{L})$ & $<0.25$ & & $\mathrm{Cu}$ & $7.00 \mathrm{E}-02$ & $+/-0.01$ \\
\hline $\mathrm{Ba}(100 \mathrm{mg} / \mathrm{L})$ & 0.865 & $+\$-0.01$ & F & $<25$ & \\
\hline $\mathrm{Cd}(1 \mathrm{mg} / \mathrm{L})$ & 0.240 & $+1-0.01$ & $\mathrm{Fe}$ & $<2 E-2$ & \\
\hline $\mathrm{Cr}(5 \mathrm{mg} / \mathrm{L})$ & 3.44 & $+1-0.05$ & $\mathbf{K}$ & 14,700 & $+/-185$ \\
\hline $\mathrm{Hg}(0.2 \mathrm{mg} / \mathrm{L})$ & 0.258 & $+/-4.8 \mathrm{E}-4$ & $\mathrm{Mg}$ & $<1.25 \mathrm{E}-1$ & \\
\hline $\mathrm{Pb}(5 \mathrm{mg} / \mathrm{L})$ & 2.89 & $+/-0.0212$ & $\mathrm{Mn}$ & $<5 E-3$ & \\
\hline \multirow[t]{2}{*}{$\mathrm{Se}(1 \mathrm{mg} / \mathrm{L})$} & $<0.025$ & & $\mathrm{Na}$ & 95,400 & $+/-475$ \\
\hline & & & $\mathrm{Ni}$ & 1.04 & $+/-0.09$ \\
\hline \multicolumn{3}{|l|}{ Other } & ${ }^{20}$ Pu mass & $<0.001$ & \\
\hline pH & 12.68 & & ${ }^{200} \mathrm{Pu}$ mass & $<0.001$ & \\
\hline $\mathrm{TDS}, \mu \mathrm{g} / \mathrm{mL}$ & 81,000 & & $\mathrm{Rb}$ & 1.28 & $+/-0.0415$ \\
\hline $\mathrm{TS}, \mu \mathrm{g} / \mathrm{mL}$ & 390,000 & & $\mathrm{Sb}$ & $<1$ & \\
\hline \multirow[t]{2}{*}{ TSS, $\mu \mathrm{g} / \mathrm{mL}$} & 310,000 & & $\mathrm{Si}$ & 44.1 & $+/-0.75$ \\
\hline & & & Sr & 1.65 & $+/-0.02$ \\
\hline $\mathrm{TIC}, \mu \mathrm{g} / \mathrm{mL}$ & 980 & $+/-17.5$ & ${ }^{90} \mathrm{Tc}$ mass & 0.545 & $+/ . .109$ \\
\hline $\mathrm{TOC}, \mu \mathrm{g} / \mathrm{mL}$ & 500 & & Th & $<2.5 \mathrm{E}-1$ & \\
\hline \multirow[t]{3}{*}{ TOT C, $\mu \mathrm{g} / \mathrm{mL}$} & 1,480 & $+/-100$ & $\mathrm{U}$ & 13 & $+/-0.51$ \\
\hline & & & $\mathrm{v}$ & $<5 E-2$ & \\
\hline & & & $\mathrm{Zn}$ & 1.35 & $+/-0.09$ \\
\hline
\end{tabular}

${ }^{a}$ Request number 1PA7763; sample number W29080896-2. 
physically agitating the sorbent with a small stirring rod when the sorbent formed small clumps and did not easily fluidize with liquid.

The column, or module, was then installed in the cell system and connected to each of the three quickconnect fittings for the column inside the cell (feed, feed return/column vent, and column effluent). If the bed became unsettled or showed evidence of air bubbles during installation or operation, it was resettled in place and any trapped bubbles were removed by introducing liquid in the upflow mode and gently tapping the side of the column. If the bed was to be returned to service after elution, the same steps were completed each time. Finally, the liquid in the column was drained to about 0.5 to $1 \mathrm{~cm}$ above the bed level before the start of supernatant feeding to minimize dilution of the supernatant.

\subsection{OPERATION OF THE CONTINUOUS SYSTEM}

Once the feed tank was full and the module was in place, a run was started by preparing the various system components. The fraction collector was set to operate remotely for the desired sample volume or collection time and number of samples. The gamma counter used to monitor the ${ }^{137} \mathrm{Cs}$ breakthrough from the module was started by initializing the multichannel analyzer program and checking the calibration for the ${ }^{137} \mathrm{Cs}$ peak. Data for the prerun background count were collected, and the automatic data collection mode was initiated.

The module feed pump was started; and feed was pumped from the feed tank, through the pump, to the column entrance tube above the bed until a liquid level of about 3 to $5 \mathrm{~cm}$ above the sorbent was reached. After all systems had been checked, the column pump was set to the desired rate and turned on. Flow rates through the column were verified by timing the fall of the liquid level in the column through a distance of $2 \mathrm{~cm}$, using the scale on the column. The level was increased by increasing the feed pump rate and then turning off the feed pump for the flow-rate check. The flow rate was checked about once per hour during normal loading tests, and the pump was adjusted to maintain the desired flow rate, if necessary. If the sorbent loading was rapid and only a few column volumes were required, or if the flow rate was high, the rate was checked more often. When the rate had to be adjusted, it was rechecked immediately after adjustment. Occasionally, when the filter downstream of the pump became partially plugged and the pressure drop rose across the filter, the flow rate that the pump delivered could be reduced and was often more difficult to keep constant; in such cases, the rate was checked more often. During most runs, the pump rate was stable for periods of several hours up to several days and did not need frequent adjustment. 
The column pump removed liquid from the bottom of the column through the bed support membrane (pore size, $20 \mu \mathrm{m}$ ) and moved it successively through a $0.45-\mu \mathrm{m}$ filter and the gamma detector, and then delivered it to the fraction collector. There was a 30- to 120-min holdup between the column and the detector, depending on the flow rate and the length of the path between the filter and detector. The approximate volume of the short path is $35 \mathrm{~mL}$; the volume of the long path is about $90 \mathrm{~mL}$. The course of the run was followed by the in-line sodium iodide detector in the cell. After the desired breakthrough of cesium had been detected, the column shutdown procedure was started. The remaining liquid in the system was pumped to the fraction collector, and the module was subsequently rinsed with distilled/deionized (DI) water or other clean liquid. This liquid rinsed the supernatant from the module and prepared it for either removal or elution/regeneration. Rinsing was continued until the cesium in the detector fell to near the initial background level. The module could then be removed from the system and taken to the gamma counter for ${ }^{137} \mathrm{Cs}$ determination. If the module contained regenerable sorbent, it could be returned to the cell and reinstalled in the system for elution, regeneration, and reloading.

The $\mathrm{pH}$ levels of some of the fractions were determined by titration with $0.1 \mathrm{~N}$ or $0.02 \mathrm{~N} \mathrm{HCl}$ to the phenolphthalein end point, followed by titration to the methyl orange end point, to determine the presence of carbonate. The fractions collected during the run were weighed, and the specific gravity of each sample was determined by weighing a known volume of the fraction. The volume of each fraction was calculated, based on its mass and density. The fraction volume and the time for its collection gave a check on the average flow rate for that fraction. Small samples were taken from each fraction $(\sim 0.5 \mathrm{~mL}$ in tared tubes) for gamma counting of the ${ }^{137} \mathrm{Cs}$. The results of the sample counts were then used to calibrate the cesium detector by correlating the sample counts obtained for each fraction to the detector output for the same fraction.

\subsection{AEA TECHNOLOGIES EIX SYSTEM}

\subsubsection{The EIX Concept}

The EIX technology for cesium recovery from tank waste supernatant was tested in the hot cell by inserting the test equipment in place of the standard column of ion-exchange resin. The laboratory-scale operation of the AEA EIX plant was conducted to test the concept on actual MVST supernatant. The EIX rig was developed and constructed for DOE under a subcontract with AEA at Harwell, UK, and delivered 
to ORNL. where it was installed in the Building 4501 Hot Cell $C$ test facility for use in testing various ionexchange materials with actual radioactive liquid waste from the MVSTs. The EIX process uses the electrolysis of water as the electrochemical driving force. Water is oxidized at the anode, producing acid and oxygen, and reduced at the cathode, yielding base and hydrogen. The electrogenerated protons are used to elute the cesium that has been previously loaded onto an ion-exchange resin. A schematic diagram of the process is shown below in Fig. 3. The passage of the current generates a basic solution of alkali metal hydroxide in the catholyte.

ORNL DWG $97 C-372$

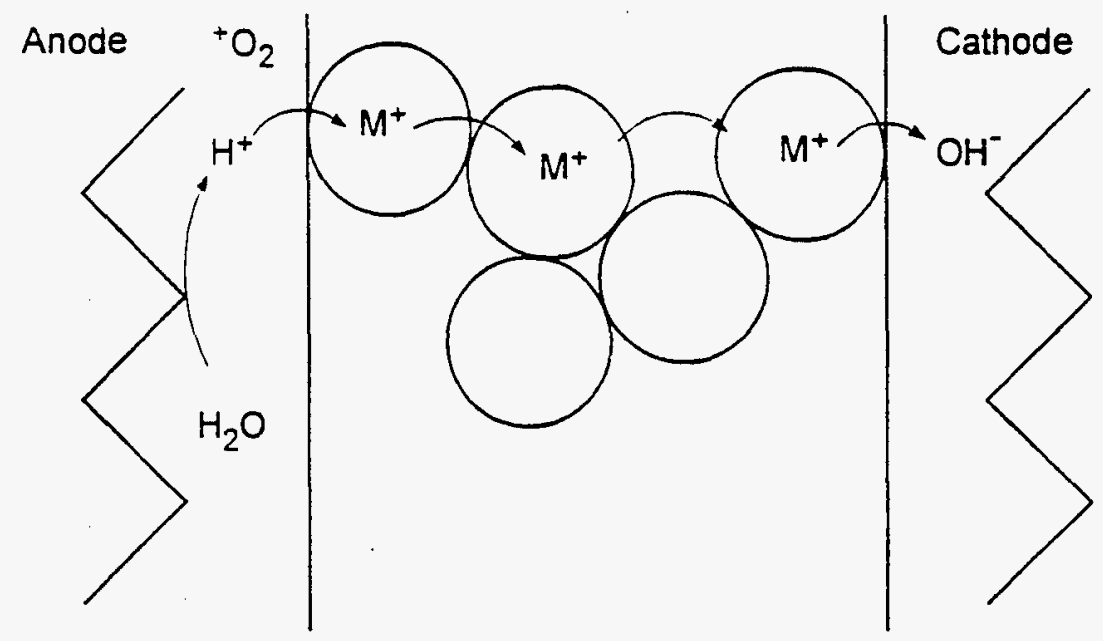

Fig. 3. Electrochemical elution of ion-exchange resins.

The EIX technology replaces the standard acid elution step in ion exchange with an electrochemical acid elution that preliminary studies suggest has the potential to reduce the volume of elution waste by more than $90 \%$, as compared with the acid elution. The EIX process also eliminates the use of chemical reagents for elution because the acid needed for elution is produced via the electrolytic dissociation of water.

\subsubsection{Description and Setup of the Experiments}

The EIX equipment was installed in place of a cesium removal column (Fig. 4), and the two cells included with the rig (Fig. 5) were filled with $5 \mathrm{~mL}$ of the RF resin supplied by AEA (RF resin made by Boulder Scientific, labeled BSC-87, and stored at AEA for several years). It was intended to be studied over repetitive loading/eluting cycles to obtain information on fouling, improvement in efficiency, and 


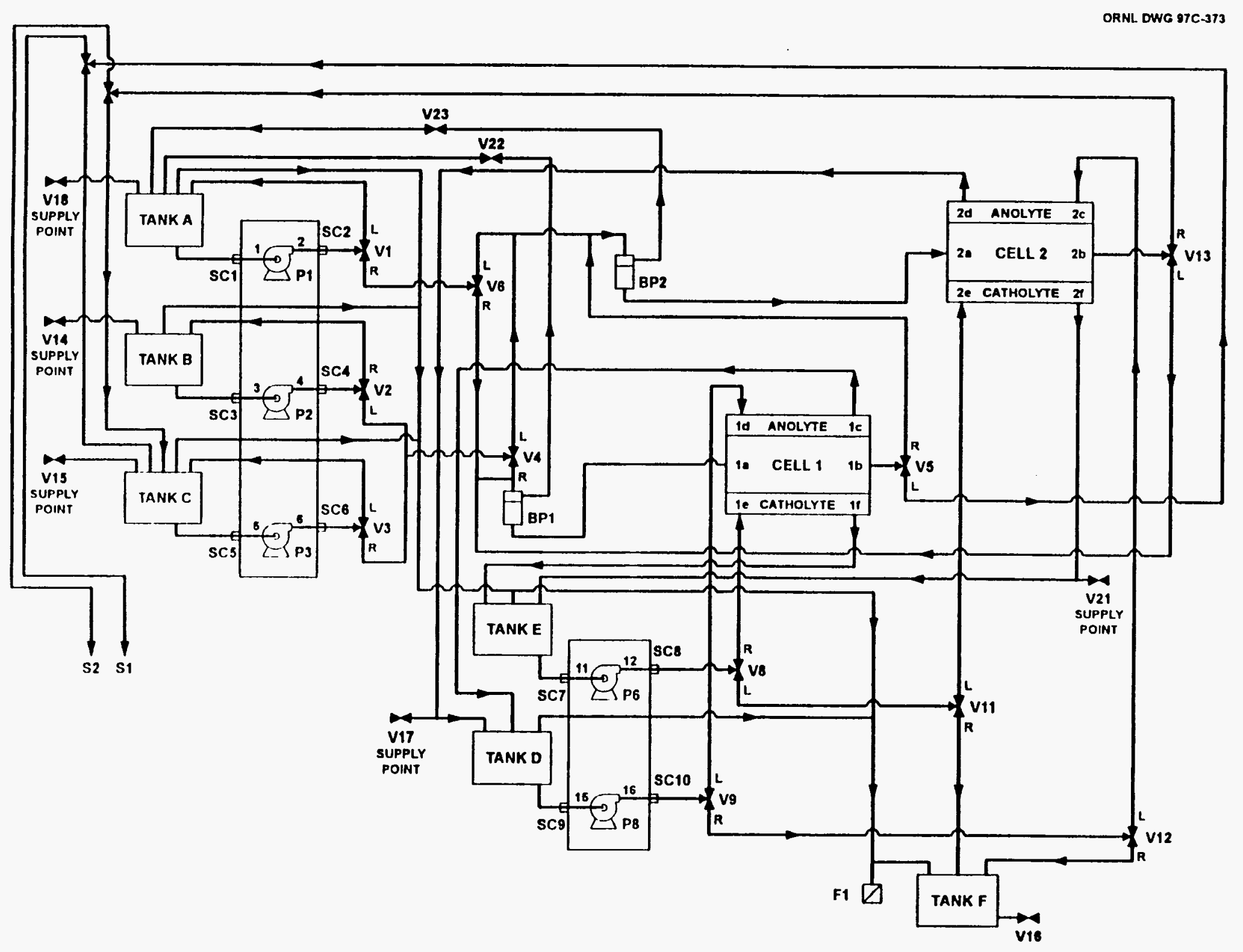

Fig. 4. AEA electrochemical ion-exchange unit. 
ORNL OWG 97C-374

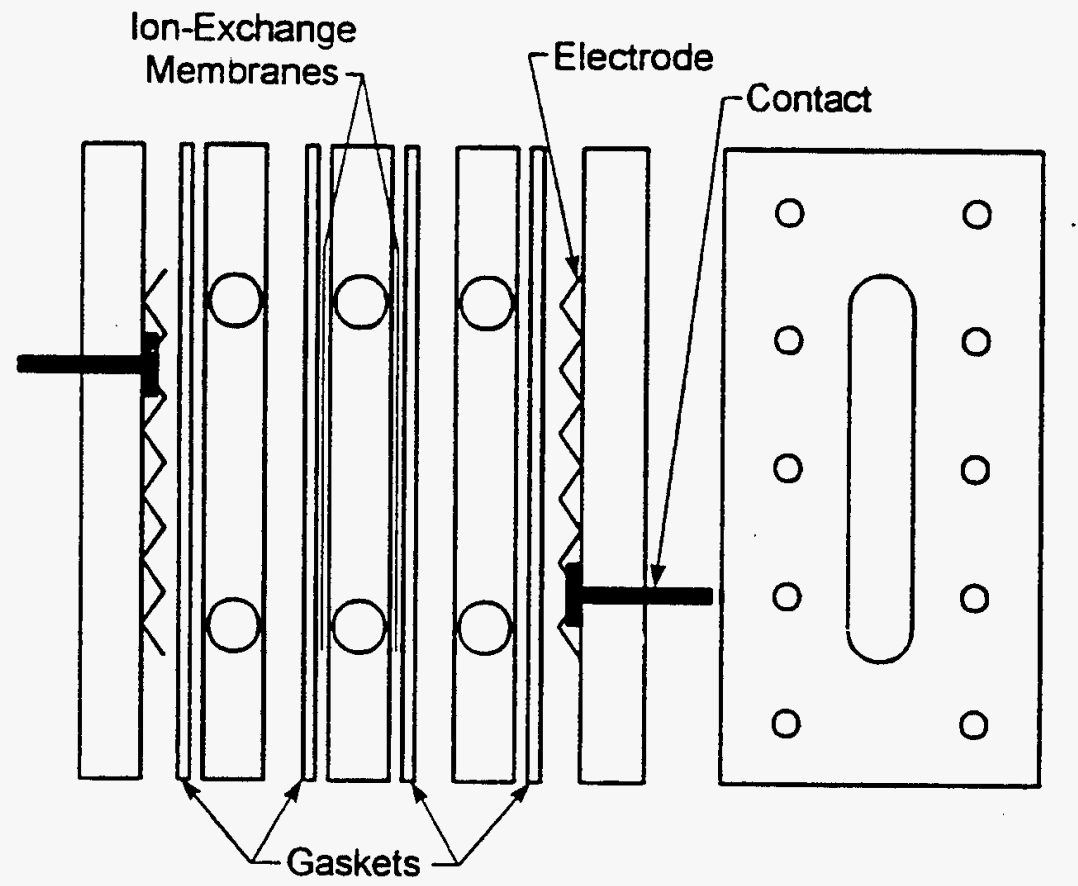

Fig. 5. Schematic diagram of EDX cell.

volume reduction over conventional acid elution, as well as to discover any design considerations to accommodate resin swelling/shrinkage.

Three members of the AEA team that developed their EIX concept and helped build the experimental rig came to ORNL to help commission and operate the equipment for the first series of runs. The system was cold tested prior to commissioning, and several minor changes were made to facilitate connection to the in-cell system of tanks, pumps, detector, and fraction collector. These changes consisted of adding hand valves for controlling flow from the cells to the detector, replacing some tubing with smaller-diameter tubing to reduce dead volume between the bubble traps and the cells as well as between the cells and the hand valves, and adding quick-connect fittings to tube ends to allow connection to the fill lines to the various tanks in the EIX rig. A flow sheet for the entire system is shown in Fig. 6.

When the system was ready to be placed inside the hot cell, the BSC-87 RF resin supplied by AEA was prepared for addition to the two EIX cells on the rig. This resin had been tested in the UK with simulant and at ORNL with the W-27 supernatant, and the results showed that it was far superior (5-10 . times more $\mathrm{CV}$ to $50 \%$ breakthrough) to the RF resin that had been used in previous tests at ORNL. This 


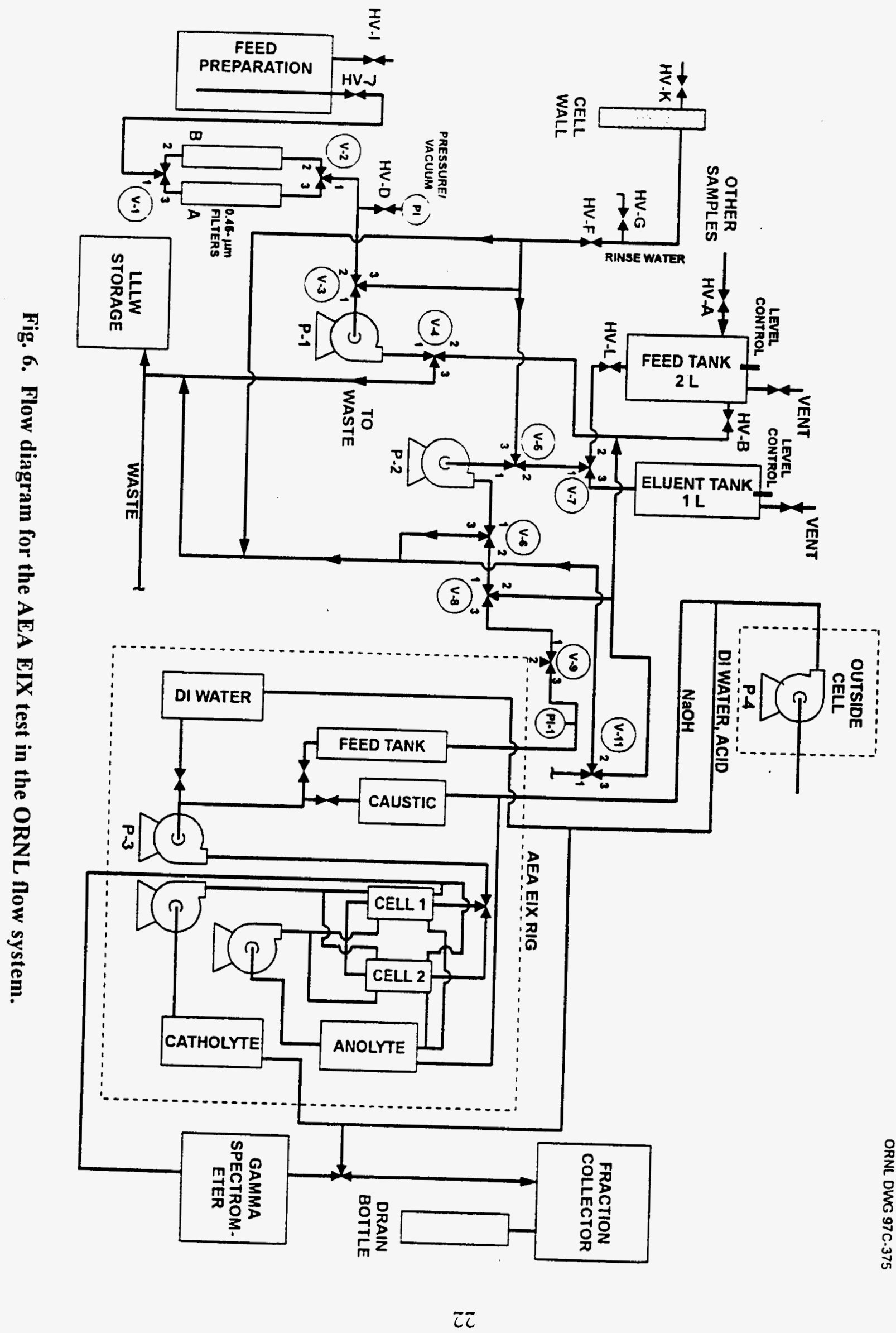


resin, which had been stored at AEA in a closed bottle on a shelf for several years, had been recently tested when the newer batch was proved to have deteriorated significantly in performance. Boulder Scientific has prepared two orders of the RF (many batches), and the performance of these batches has been quite variable. Approximately $9 \mathrm{~mL}$ of dry $\mathrm{RF}$ resin was prepared by treating with $50 \mathrm{~mL}$ of $0.5 \mathrm{NHNO}_{3}$, which generated a large quantity of gas at first contact. After this first batch of acid had been removed, a second $50-\mathrm{mL}$ volume was added, with only a slight amount of gas being produced. The resin was then rinsed with $100 \mathrm{~mL}$ of $\mathrm{DI}$ water in $50-\mathrm{mL}$ increments. It was converted to the sodium form by treatment with $25 \mathrm{~mL}$ of $1 \mathrm{~N} \mathrm{NaOH}$ and allowed to stand for 10 min before the caustic was removed and another $25 \mathrm{~mL}$ of $1 \mathrm{~N} \mathrm{NaOH}$ was added. After $10 \mathrm{~min}$, the second volume of $1 \mathrm{~N} \mathrm{NaOH}$ was removed, and the resin was rinsed with $50 \mathrm{~mL}$ of DI water, followed by $100 \mathrm{~mL}$ of DI water. Each of the two cells was then filled with $5 \mathrm{~mL}$ of resin and secured in preparation for placement in the hot cell.

The feed for the run was some of the same batch of original W-27 supernatant that had been obtained in April 1995 and adjusted to $\mathrm{pH} 13.3$ using $\mathrm{NaOH}$ pellets. This batch had been used in previous tests of the RF, CST, CS-100, and other resins (see Table 1). The feed supernatant was filtered before transfer to the AEA rig feed tank during the pumping sequence to fill the normal system feed tank. That tank was then used to supply the feed to the AEA rig feed tank.

\section{EXPERIMENTAL RESULTS}

\subsection{PREPARATION OF SUPERNATANT FOR OPERATION}

MVST W-27 supernatant was used as the feed for most of the experimental runs. Once the pH had been adjusted in the supernatant container, the container was transferred to the Cell $\mathrm{C}$ feed transfer area for pumping to the system feed tank. The bottles of supernatant were allowed to settle for up to 3 days to allow the calcium and magnesium compounds formed during $\mathrm{pH}$ adjustment to settle to the bottom before the solution was pumped to the column feed tank through the $0.45-\mu \mathrm{m}$ filter. The feed tank was filled at a flow rate of about $30 \mathrm{~mL} / \mathrm{min}$. (A level probe in the tank shuts off the pump approximately $5 \mathrm{~cm}$ from the top.) Once the tank had been filled, the lines were emptied back to the transfer container, the pump head was rinsed with distilled water to prevent salt crystallization in the head, and water was left in the

head. When the tank pumping was first started, some solids were observed in the transparent lines to the filters, but the lines were clear during most of the pumping time. The filter retained a slight yellow color, 
even after rinsing with water, due to the particulates trapped; however, it was not plugged to the flow of liquid. During subsequent fillings of the feed tank from the same bottle, the lines remained clear. Those feeds which had been adjusted to $\mathrm{pH} 14$ settled more slowly and were more difficult to filter, sometimes requiring two filtrations in the course of filling a given tank.

The solution in the feed tank after transfer and filtration was clear and slightly yellow; the bottom of the stainless steel tank was easily visible from the top of the tank through $40 \mathrm{~cm}$ of supernatant. The exception was during the filling from the bottle adjusted to $\mathrm{pH} 14$ for a CST test in which the feed transfer filter failed and allowed unfiltered material to pass to the feed tank. In that case, the feed to the column was stopped before any material entered the feed pump, and a temporary tank was installed and filled with fresh filtered feed. Then the column was restarted without incident within about $65 \mathrm{~min}$.

Supernatant for the CsRD qualification run was pumped directly from the transfer bottle to the feed tank with no adjustments or modifications except during the initial sampling for analytical tests.

\subsection{SUPERLIG ${ }^{\circledast}$ 644C AT $1 N$ HYDROXIDE AND $3.5 \mathrm{CV} / \mathrm{h}$}

The SuperLig ${ }^{\otimes} 644 \mathrm{C}$ for this run was prepared by measuring $4.657 \mathrm{~g}$ of dry resin into a column (6.2 $\mathrm{mL}$, packed dry) and proceeding as in the previous run (wetting with DI water, followed by $2 \mathrm{~N}$ $\mathrm{NaOH}$ ), and then treating with a surrogate feed made to $5 \mathrm{~N}$ in $\mathrm{NaNO}_{3}$ and $1 \mathrm{~N}$ in $\mathrm{NaOH}$. The W-27 feed made to $\mathrm{pH} 14$ was used in this run, which was planned to be a multiple load-and-elute experiment where (1) the cesium was loaded and then eluted with $0.5 \mathrm{NHNO}_{3}$ and (2) the resin was regenerated with $2 \mathrm{~N}$ $\mathrm{NaOH}$ and then reloaded with the cesium in the W-27 feed. For this set of runs, the first loading was done with the normal amount of cesium in the feed $\left(1.1 \times 10^{-5} \mathrm{M}\right)$, and the following three loadings were done with approximately seven times as much cesium (in the form of cold cesium) added as cesium nitrate, giving a measured total of about $7.5 \times 10^{-5} \mathrm{M}$ cesium in the feed. The loading was done at a flow rate of $3.5 \mathrm{CV} / \mathrm{h}$ in the downflow mode. The column volume used in flow-rate measurements was determined by measuring the sorbent bed height during the loading process after several $\mathrm{CV}$ of supernatant had passed through the bed and the height had stabilized. Because of the low density of the SuperLig 644 in the $5 \mathrm{M}$ salt solution, a special weighted bed follower, developed by J. L. Collins, was used to keep the bed packed during loading, elution, and regeneration. For example, the loading took place with the bed at $10.3 \mathrm{~cm}^{3}$, the water rinse of the bed after loading increased the volume to $13.0 \mathrm{~cm}^{3}$, and elution of the bed reduced the volume to $8.6 \mathrm{~cm}^{3}$. 
The first loading used $\mathrm{pH} 14$ feed with $1.1 \times 10^{-5} \mathrm{M} \mathrm{Cs}$ and a flow rate of $3.5 \mathrm{CV} / \mathrm{h}$ with a column volume of $10.2 \mathrm{~cm}^{3}$ and an ambient temperature of $28^{\circ} \mathrm{C}$. The initial flow of supernatant through the column produced a reddish-brown color that gradually decreased over about $2 \mathrm{CV}$. The color could be followed all the way to the fraction collector. Some pink discoloration of the downstream filter was also noted, but no plugging occurred. The Cs breakthrough began to be observed when less than $10 \mathrm{CV}$ had passed through the bed. The loading continued until about $60 \%$ breakthrough was indicated by the in-line detector; $50 \%$ breakthrough occurred at about $167 \mathrm{CV}$. The column was then rinsed with DI water and prepared for elution. The rinse expanded the bed to a volume of $12.9 \mathrm{~cm}^{3}$ and also resulted in some color being released from the column. The loading curve is shown in Fig. 7.

The elution was completed using downflow through the bed with $0.5 \mathrm{NHNO}_{3}$ at approximately the same flow rate as the loading. As soon as acid began flowing through the bed, it began to shrink. After about $3 \mathrm{CV}$ had passed through the bed, the volume had decreased to $10 \mathrm{~cm}^{3}$ and continued to decrease until it reached $9.5 \mathrm{~cm}^{3}$ by the end of the elution step. A total of $90 \mathrm{~mL}$ of acid was used in the elution. The elution curve is shown in Fig. 8. The in-line detector curve flattens at about $5 \mathrm{C} / \mathrm{C}_{0}$, where the detector is completely saturated and will not record higher readings. Fractions collected during the elution were analyzed to develop the total elution curve, with the peak occurring at about $36 \mathrm{C} / \mathrm{C}_{0}$ at $4 \mathrm{CV}$ of acid. The column was rinsed with DI water following the elution, and the water was allowed to remain in the column until the regeneration step.

The column was regenerated with $50 \mathrm{~mL}(5 \mathrm{CV})$ of $2 \mathrm{NNaOH}$ in the upflow mode at a $0.5-\mathrm{mL} / \mathrm{min}$ flow rate. The bed had a volume of $9.2 \mathrm{~cm}^{3}$ at the start of regeneration. Color, which began coming off the bed as the first $\mathrm{CV}$ of regenerant passed through, continued for about $2 \mathrm{CV}$. The regeneration was continued, with the final volume of the bed increasing to $11.9 \mathrm{~cm}^{3}$. The bed was then rinsed with $5 \mathrm{CV}$ of the surrogate salt solution and readied for the next loading. During the salt rinse, it was noted that many small bubbles had formed throughout the bed. Efforts were initiated to remove them by applying a vacuum on the bed and suddenly releasing it for a series of four cycles. Following this treatment, the bed was reduced to a volume of $10.5 \mathrm{~cm}^{3}$ for the start of loading; no bubbles could be seen.

The next loading was completed by using feed that had nonradioactive Cs added to give a total Cs concentration of $7.5 \times 10^{-5} \mathrm{M}$; the $\mathrm{pH}$ was still at 14 , and all other concentrations remained at the previous level. Feed to the column was again at $3.5 \mathrm{CV} / \mathrm{h}$, and slight color was seen as the feed initially passed through the bed but disappeared after about $3 \mathrm{CV}$. Breakthrough of the cesium was almost immediate. 
ORNL DWG 97C-357

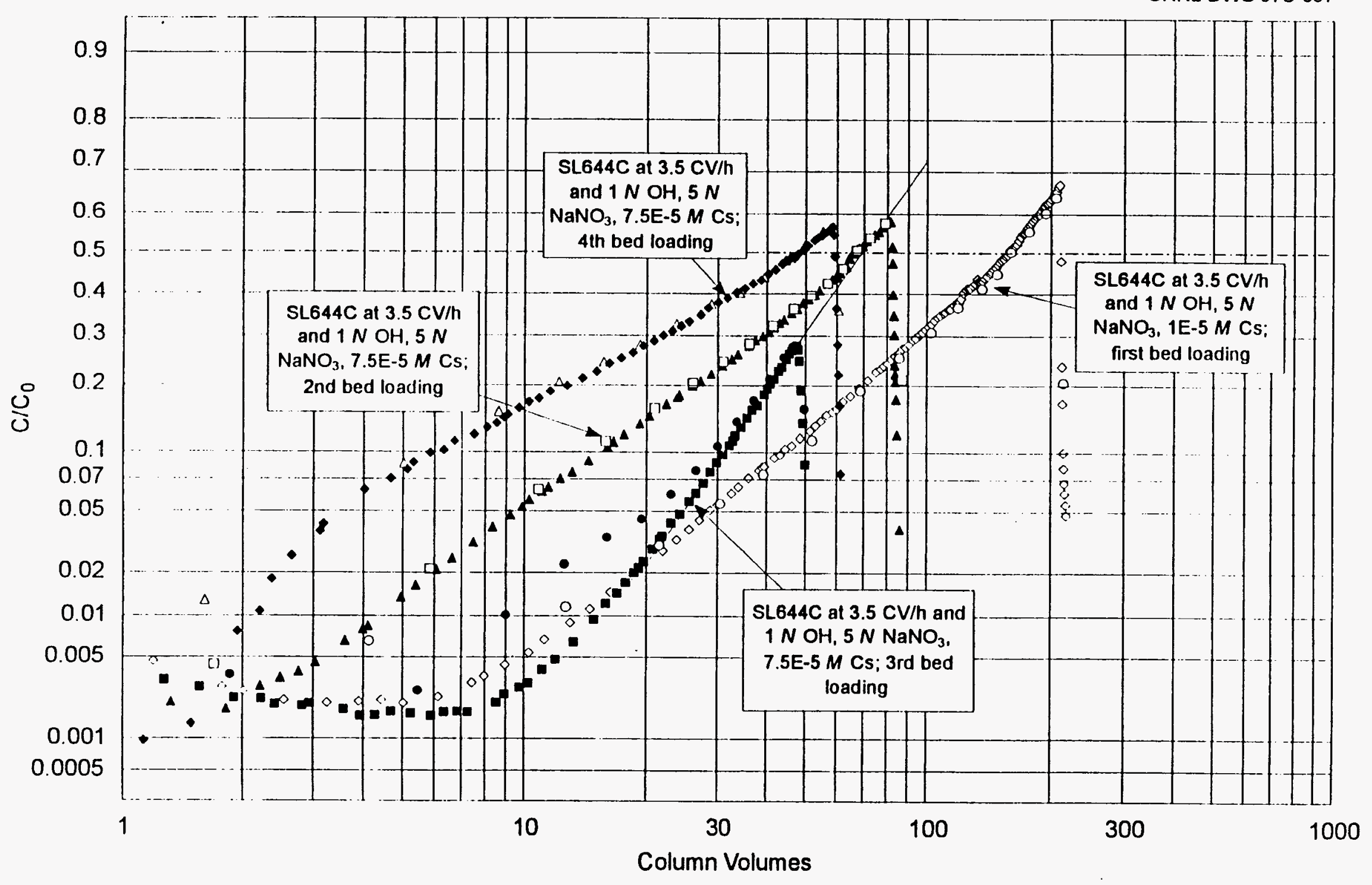

Fig. 7. Loading curves for SuperLig ${ }^{\star} 644 \mathrm{C}$ cycles at $3.5 \mathrm{CV} / \mathrm{h}$ at $1 \mathrm{MOH}$ and $7.5 \times 10^{-5} \mathrm{MCs}$. 


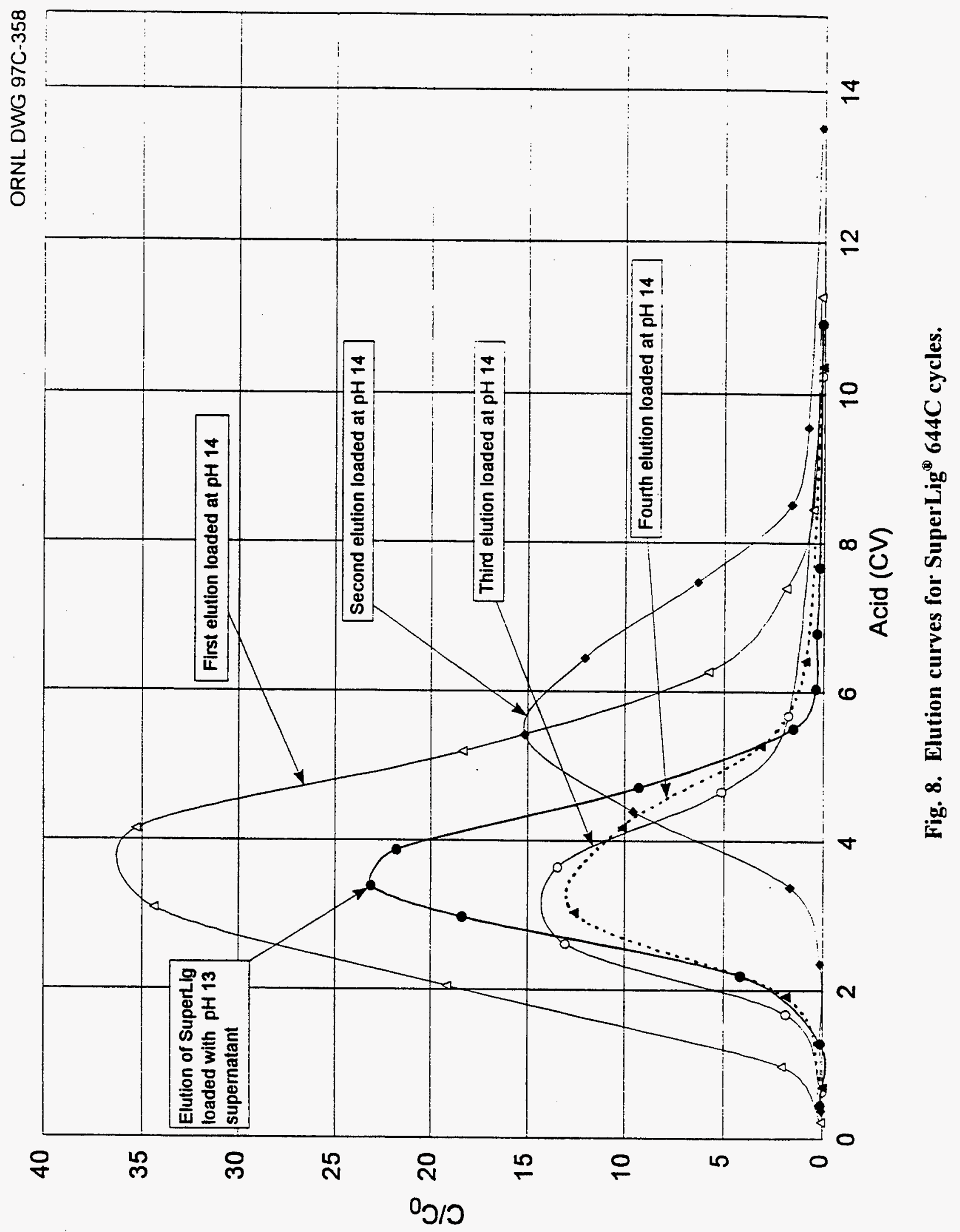


Whether this was due to incomplete elution and regeneration or to the bubble removal process, causing flow distribution problems in the bed, cannot be determined. The loading curve shown in Fig. 7 was approximately parallel to the first curve, but the $50 \%$ breakthrough occurred at $77 \mathrm{CV}$. The rinse was performed with DI water, and the column was prepared for the elution. The bed volume at the end of the supernatant feed step was $10.2 \mathrm{~cm}^{3}$ but expanded to $12.7 \mathrm{~cm}^{3}$ following the rinse. The elution was conducted in the same manner as the previous one, but a total of $12 \mathrm{CV}(120 \mathrm{~mL})$ acid was used. The elution curve, shown in Fig. 8, was displaced about $2 \mathrm{CV}$ to the right from the first elution curve, with the peak of $15 \mathrm{C} / \mathrm{C}_{0}$ occurring at about $5.5 \mathrm{CV}$. Some brown color was removed from the bed in the first few column volumes, and the bed shrank to $8.7 \mathrm{~cm}^{3}$ by the end of the elution step. Small bubbles were seen at the bottom of the bed after about $3 \mathrm{CV}$, and more bubbles began to appear on the sides and near the top as the elution continued. The bubbles increased in size and became more numerous until the elution was completed.

Before the regeneration was attempted, the bubbles were removed by applying a vacuum/release sequence to the bed, as described before. When this was completed, the column volume was $8.4 \mathrm{~cm}^{3}$. The regeneration was started in the upflow mode at about $3 \mathrm{CV} / \mathrm{h}$ with $2 \mathrm{~N} \mathrm{NaOH}$. As in the first regeneration, a reddish-colored band came off the column but grew fainter and disappeared within the first $2 \mathrm{CV}$. During this time, a few solids could be seen below the filter and in some of the lines. The final volume after regeneration was $11.4 \mathrm{~cm}^{3}$. The regeneration was followed by $6 \mathrm{CV}$ of the surrogate salt, and this material was left in the column until the start of the next loading cycle. At the end of the elution, one small bubble was seen near the top of the bed. Following the rinse with the surrogate salt solution, more bubbles were visible, and these were removed by three vacuum/release sequences. Some small solids could be seen in the liquid above the bed, possibly from fines in the bed; however, their exact source was not determined. The final bed volume in preparation for the next loading was $10.4 \mathrm{~cm}^{3}$.

The third loading, again at $3.5 \mathrm{CV} / \mathrm{h}$, was planned to continue until the second loading curve was confirmed, or about $25-30 \% \mathrm{C} / \mathrm{C}_{0}$. At the start of loading, color left the column and could be seen collecting on top of the filter. The bed shrank slightly during the first few $\mathrm{CV}$ to about $10.25 \mathrm{~cm}^{3}$. During the first several $\mathrm{CV}$, no breakthrough was seen on the in-line detector and initial breakthrough did not occur until about 8-9 CV. Analysis of the collected fractions indicated that a bubble had possibly become trapped in the detector tube and was giving a false low reading. When the run was completed at about $25 \%$ breakthrough, the curve was extrapolated to the $50 \%$ point to give a $50 \%$ breakthrough of about $65 \mathrm{CV}$ 
using data from the samples analyzed externally. The column was then rinsed with DI water, and the bed expanded to $13 \mathrm{~cm}^{3}$. No bubbles were observed during the loading or rinse cycle. The loading curve is shown in Fig. 7.

The elution was preceded with a 5-CV rinse with DI water in an effort to prevent bubble formation. Considerable color was noted during the first flow of the DI water through the bed. The elution was completed with over $8 \mathrm{CV}$ of $0.5 \mathrm{~N} \mathrm{HNO}_{3}$ and resulted in a peak of $14 \mathrm{C} / \mathrm{C}_{0}$ in the effluent at $3 \mathrm{CV}$ of eluent. During the elution, the bed shrank from $13 \mathrm{~cm}^{3}$ to $8.4 \mathrm{~cm}^{3}$ (see the curve in Fig. 8). After the elution had been completed, the column was rinsed with DI water with no volume change in the column.

Regeneration prior to the fourth loading was completed in the downflow mode (upflow was used in the first three regenerations), using approximately $10 \mathrm{CV}$ of $2 \mathrm{~N} \mathrm{NaOH}$. Color was removed from the bed almost immediately and continued for about $2 \mathrm{CV}$, and the bed expanded to $11.5 \mathrm{~cm}^{3}$. The surrogate salt solution was then pumped through the column, resulting in a bed volume of $10.9 \mathrm{~cm}^{3}$. No bubbles were observed during any of these operations, and no vacuum sequence was used before the fourth loading.

The fourth loading was begun at $3.5 \mathrm{CV} / \mathrm{h}$ and resulted in color leaving the column again, but not as much as in previous loadings. Also, the bed volume decreased slightly to $10.5 \mathrm{~cm}^{3}$ during the loading. The loading curve (see Fig. 7) began at a steep slope but gradually decreased through the 5- to 10-CV range, almost becoming parallel to the second loading by the time the $50 \%$ breakthrough point was reached at about $50 \mathrm{CV}$. The column was rinsed with DI water following the loading, and the bed expanded to $13 \mathrm{~cm}^{3}$ during the rinse. The three loadings that exceeded $50 \%$ showed an increase in slope as the curves passed $40-45 \%$ breakthrough. The change in slope was noted on both the in-line detector and in the fractions that were analyzed later. The change can be seen in the plot of the loading curves.

The column was rinsed and then eluted as in the previous loadings; the results are shown in Fig. 8. Before the elution was started, a 3-CV rinse with DI water was concluded. Additional volumes (11 CV) of acid were used in an attempt to remove nearly all of the cesium from the column. The curve was very similar to the third elution, with the peak occurring at about $3 \mathrm{CV}$ and a concentration of $13 \mathrm{C} / \mathrm{C}_{0}$ in the effluent. The bed decreased to a volume of $8.4 \mathrm{~cm}^{3}$ during the elution, and stayed at that volume during a rinse with DI water. The column was then drained, removed from the system, and stored for later reuse or additional analysis. Analyses showed that $5.2 \mu \mathrm{Ci}$ of ${ }^{137} \mathrm{Cs}$ (the amount in about $0.5 \mathrm{~mL}$ of supernatant) was left on the column. In addition, ${ }^{60} \mathrm{Co}$ and ${ }^{106} \mathrm{Ru}$ were apparently concentrated on the resin, with 4.5 and $0.11 \mu \mathrm{Ci}$, respectively, present. The amount of ruthenium in the supernatant was below the detection 
limit; however, the ${ }^{60} \mathrm{Co}$ concentration in the column was more than 20 times that of the same volume of supernatant.

\subsection{RF RESIN AT $1 N$ HYDROXIDE AND 3.5 CV/h}

An experiment was completed using RF resin obtained from the ORNL REDC (REDC batch) of $-60+80$ mesh size, in which the feed rate through the bed was 3.5 CV/h. Three previous experiments were completed with resin obtained directly from Bibler (i.e., the Bibler batch) and supernatant at $0.1 \mathrm{~N}$ hydroxide concentration. ${ }^{13}$ For the current run, $6.029 \mathrm{~g}$ of resin (tapped volume, $8.3 \mathrm{~cm}^{3}$ ) was treated with $10 \mathrm{CV}$ of $0.5 \mathrm{M} \mathrm{HNO}_{3}$, followed by $7 \mathrm{CV}$ of DI water. During this treatment, the bed volume decreased to $7.3 \mathrm{~cm}^{3}$. The bed was then treated with $2 \mathrm{M} \mathrm{NaOH}$ for $10 \mathrm{CV}$ at the expanded volume of resin and rinsed with DI water for $3 \mathrm{CV}$. The resin expanded to $13.86 \mathrm{~cm}^{3}$ during caustic treatment. Approximately $10.7 \mathrm{~cm}^{3}$ of the resin was placed in the $1.5-\mathrm{cm}-\mathrm{ID}$ test column to give a bed height of $6.5 \mathrm{~cm}$. The weighted bed follower described above for the SuperLig ${ }^{\otimes} 644 \mathrm{C}$ was also used during this run. The column was filled with a surrogate salt solution of $5 \mathrm{~N} \mathrm{NaNO}_{3}$ and $1 \mathrm{~N} \mathrm{NaOH}$ in preparation for loading.

The column was installed as described above, and supernatant feed was started through the bed at 3.5 CV/h. The same supernatant was also used for the first SuperLig loading in the multiple loading run described above ( $1 \times 10^{-5} \mathrm{M}$ cesium). Once feed was started through the bed, the effluent became a brown color that lasted for 2 to $3 \mathrm{CV}$; the dark color could be seen as it passed through the tubing and filter. During the first $4 \mathrm{CV}$ of feed through the bed, the bed volume increased to about $11.1 \mathrm{~cm}^{3}$ and remained there for the rest of the loading. During the run, it was difficult to maintain a constant flow rate because of bubbles arising in the lines and migrating to the column pump. The loading was continued to $70 \%$ breakthrough of the cesium. The loading curve (Fig. 9) shows that the initial breakthrough did not occur until $7 \mathrm{CV}$, and then curve was very steep to $50 \%$ at about $20 \mathrm{CV}$. The additional curve shown in the graph is a plot of the results obtained by PNNL using the same batch of RF resin (sent to Hanford just before the test) to treat diluted supernatant from Hanford tank 241-AW-101. ${ }^{16}$ Both curves generally followed the curves for past runs with RF resins. ${ }^{1}$ The column was rinsed with several CV of DI water following the loading in preparation for the elution.

The $\mathrm{RF}$ resin was eluted using $0.5 \mathrm{~N} \mathrm{HNO}_{3}$ in the downflow mode at about $3.5 \mathrm{CV} / \mathrm{h}$. The volume of the bed was $12.9 \mathrm{~cm}^{3}$ after the previous loading and water rinse but decreased to $9.1 \mathrm{~cm}^{3}$ after elution 
ORNL DWG 97C-359

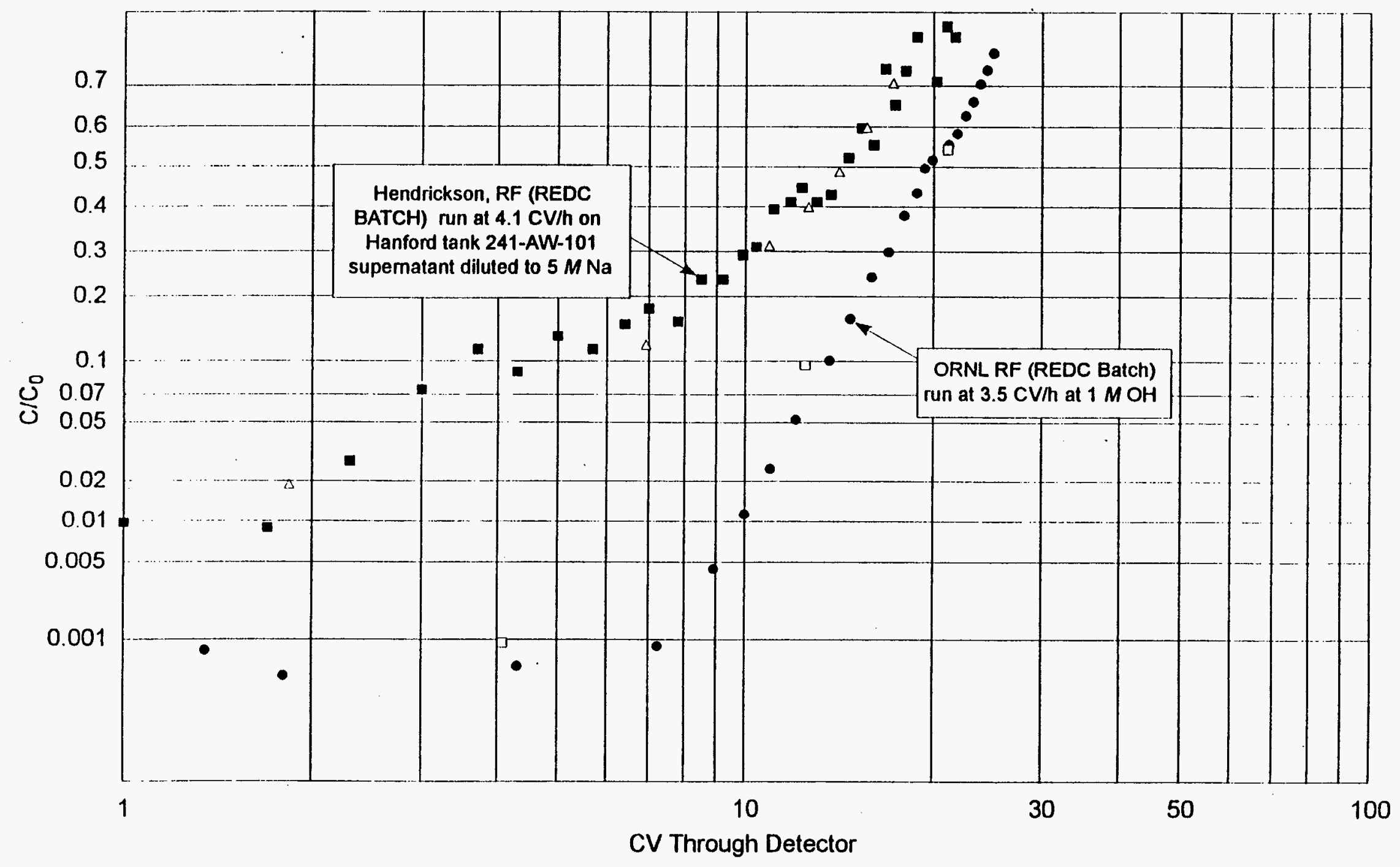

Fig. 9. Loading curve for the RF resin at 3.5 CV/h, using MVST W-27 supernatant at pH 14. 
and rinse. The elution curve (Fig. 10) shows a peak of about $3.4 \mathrm{C} / \mathrm{C}_{0}$ at about $6 \mathrm{CV}$ of eluent. The curve is very broad and does not return to the baseline after $12 \mathrm{CV}$. After the elution and rinse had been completed, the column was drained and transferred from the system to storage.

\subsection{CST-38 B AT $1 N$ HYDROXIDE AND $7.5 \times 10^{-5} M$ CESIUM}

The experimental system was set up using the UOP Batch 38B CST sample from the same bottle as that used in the previous CST runs. Ten milliliters of CST (mass, $11.873 \mathrm{~g}$ ) was added to a $10-\mathrm{mL}$ graduated cylinder. The CST was placed in the column and tapped to the minimum level $(6.3 \mathrm{~cm})$. Then, $100 \mathrm{~mL}$ of DI water and $70 \mathrm{~mL}$ of $1 \mathrm{~N} \mathrm{NaOH}$ were successively passed through the column in the upflow mode to remove fines and settle the bed. About $10 \mathrm{~mL}$ of the caustic remained above the bed, and the column was left in this manner for installation in the cell system. (The volume of the bed before the start of the run was $10.48 \mathrm{~mL}$.)

The MVST W-27 supernatant bottle used for this CST loading was prepared by adding solid $\mathrm{NaOH}$ until the hydroxide concentration was $1 \mathrm{~N}$. The titrated $\mathrm{pH}$ of the feed was 13.99. At this time, the total cesium concentration of the feed was adjusted to $7.48 \times 10^{-5} \mathrm{M}$ by using $\mathrm{CsNO}_{3}$. The analysis of the feed is summarized in Table 2 .

Once the column had been installed in the system, feed supernatant was pumped to the column at an initial flow rate of about $6 \mathrm{CV} / \mathrm{h}$. Flow was continued until the effluent showed a ${ }^{137} \mathrm{Cs}$ level greater than $55 \%$ of the level in the feed. The column was then washed with water, drained, and prepared for counting and storage. The results of the run are shown in Fig. 11. Because of the increased level of total cesium in the feed, the $50 \%$ breakthrough point was expected to be at a significantly (approximately $30 \%$ ) lower $\mathrm{CV}$ than that for the previous run, which was made at the same flow rate but with feed containing lower $\mathrm{Cs}$ and hydroxide concentrations. The results showed a loading curve parallel to the previous curve, as expected, with the $50 \%$ breakthrough occurring at $272 \mathrm{CV}$, the $10 \%$ breakthrough at $122 \mathrm{CV}$, and the $1 \%$ breakthrough at $55 \mathrm{CV}$. The $50 \%$ breakthrough is about $79 \%$ of the breakthrough for the feed with lower Cs and hydroxide concentration-well within the prediction. No difficulties with the system were observed during operation.

Calculations for the loading of the column, based on the ${ }^{137} \mathrm{Cs}$ content and the volume of the feed, gave $29,091 \mu \mathrm{Ci}$ fed (i.e., $9.34 \mu \mathrm{Ci} / \mathrm{mL} \times 3115 \mathrm{~mL}$ ); analysis of the effluent from the column showed that 


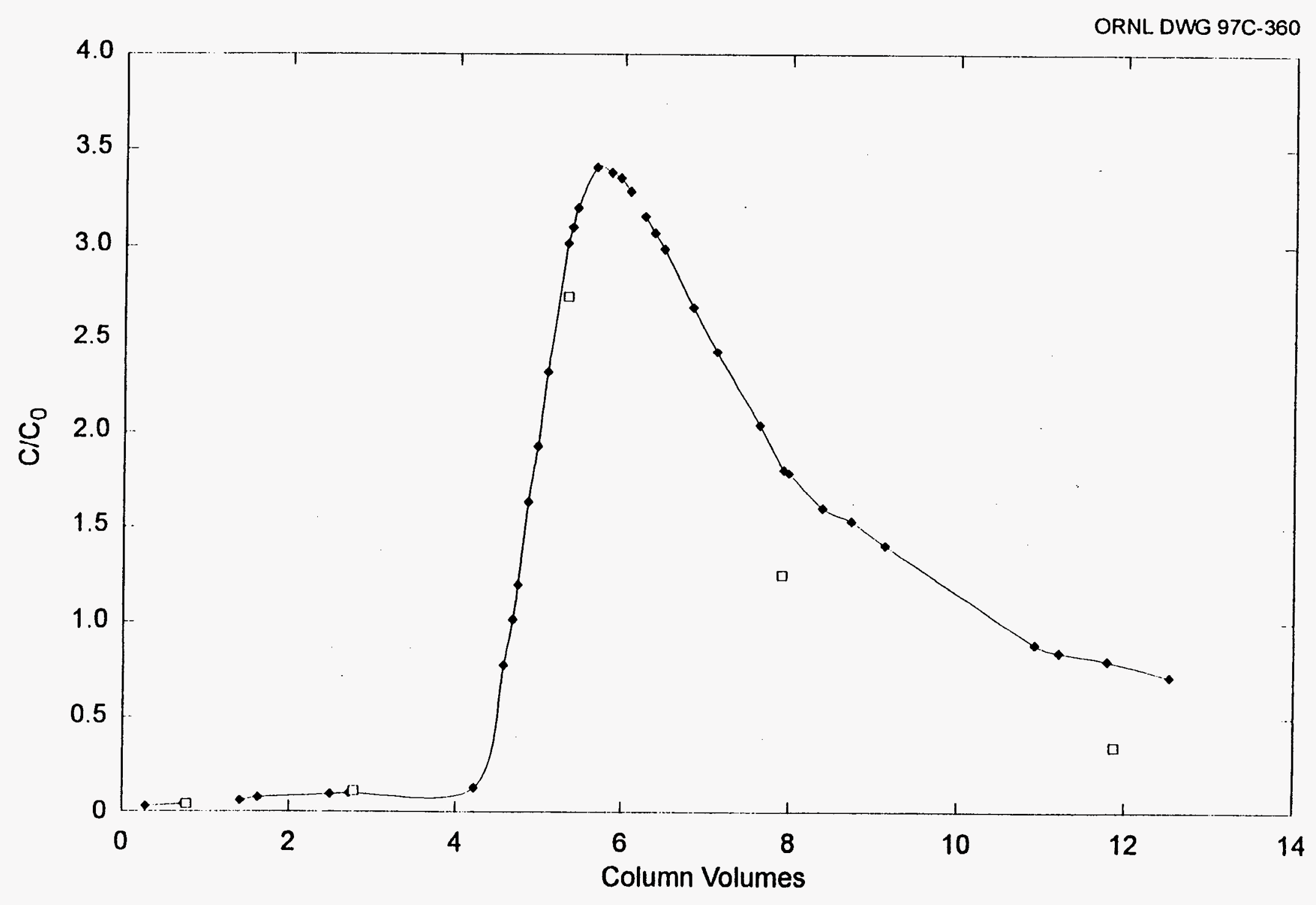

๘

Fig. 10. Elution curve for the RF resin at $3.5 \mathrm{CV} / \mathrm{h}$. 
ORNL DWG 97C-361R

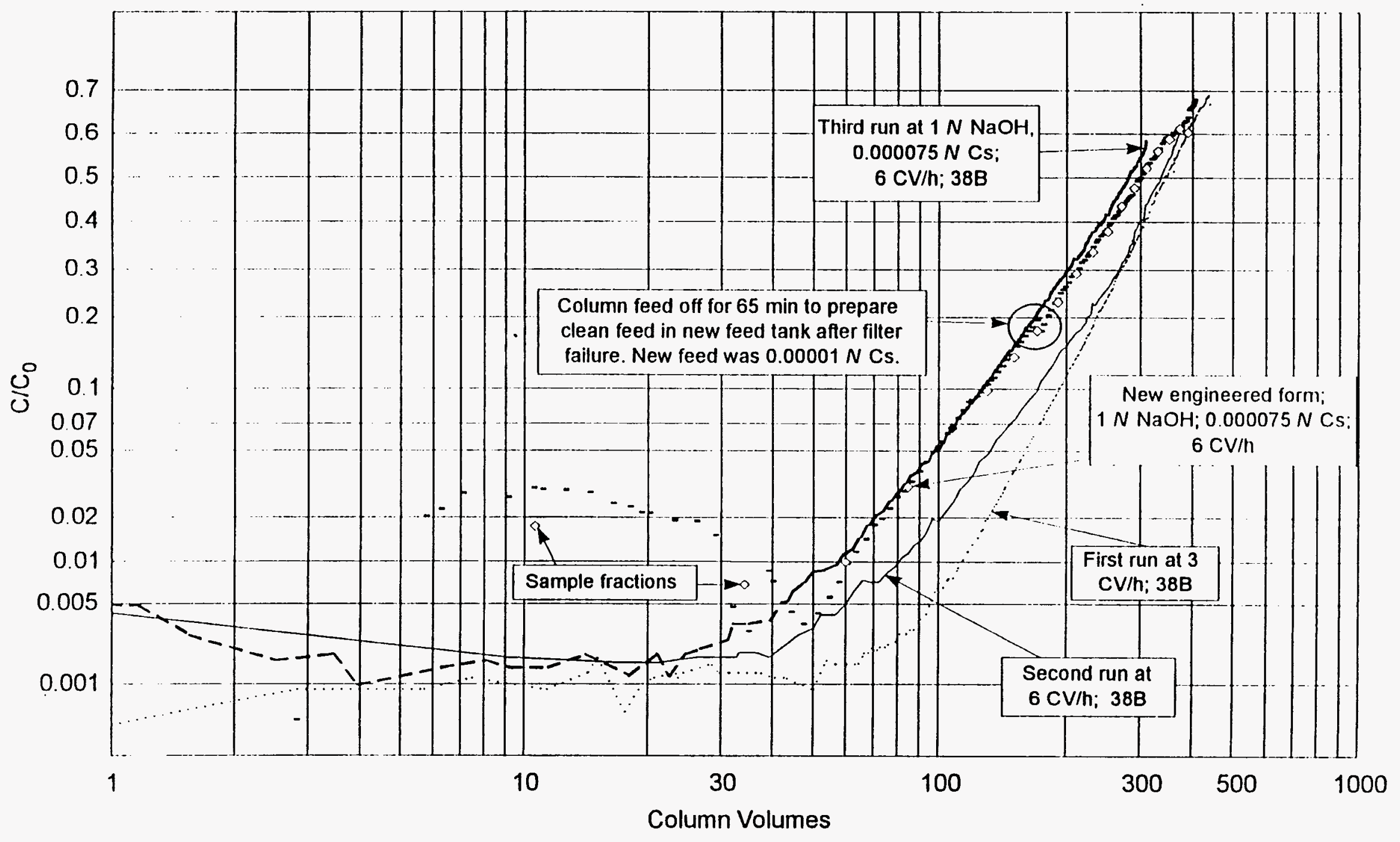

Fig. 11. Loading curves for CST-38B and -0001 at $6 \mathrm{CV} / \mathrm{h}$, using supernatant at $\mathrm{pH} 14$ and $7.5 \times 10^{-5} \mathrm{M} \mathrm{Cs}$. 
$5,761 \mu \mathrm{Ci}$ passed through the column. Counting of the column in its 3.2-mm-thick stainless steel containment vessel after its removal from the cell showed that $20,194 \mu \mathrm{Ci}$ was present, leaving about $3,136 \mu \mathrm{Ci}(10.8 \%$ of cesium fed) unaccounted for.

\subsection{CST-0001 AT $1 N$ HYDROXIDE AND $7.5 \times 10^{-5} M$ CESIUM}

The experimental system was set up to start CST run 4 using the UOP IONSIV ${ }^{\circledR}$ IE-911 (lot 999096810001) CST received on March 27, 1996, from the UOP plant in Whistler, Alabama. (This is the production-engineered form of the CSTs.) The column was prepared by tapping $10.590 \mathrm{~g}$ of sorbent, measured in a $10-\mathrm{mL}$ graduated cylinder, to the minimum volume $(6.35 \mathrm{~cm})$. Then, $70 \mathrm{~mL}$ of DI water was passed through the column in the upflow mode to remove fines and settle the bed. About $0.25-0.3 \mathrm{~mL}$ of fines was removed from the bed. After the first contact, the CST was fairly dusty and the water was "milky," with numerous small particles present. The water was followed by $100 \mathrm{~mL}$ of $1 \mathrm{~N} \mathrm{NaOH}$, and the $\mathrm{NaOH}$ was left in the column for the weekend. About $1 \mathrm{~mL}$ of the caustic remained above the bed, and the column was left in this manner for installation in the cell system. (The final volume of the bed before the start of the run was $10.35 \mathrm{~mL}$.)

The supernatant feed used for most of this CST loading was used in the previous run with the -38B CST; it had a titrated $\mathrm{pH}$ of 13.97 and was $7.5 \times 10^{-5} \mathrm{M}$ in Cs. The initial $175 \mathrm{CV}$ came from the first feed bottle and had a high Cs concentration. During the run, a second bottle of supernatant that had been prepared to the same $\mathrm{pH}(13.98$, as measured by titration) was used for the last $130 \mathrm{CV}$ of feed to the column. The second bottle of supernatant, however, did not contain additional Cs; thus, its cesium concentration was only about $1 \times 10^{-5} \mathrm{M}$. During the process of filling the tank with feed from the new bottle, the filter failed and solids entered the feed tank. Before solids reached the feed pump, the system was shut down and a temporary tank was prepared with clean feed for the remainder of the run. The feed was stopped for about $65 \mathrm{~min}$; after restart, a small dip in the loading curve, with a return to the previous slope, was noted-which was the expected response.

Once the column had been installed in the system, the feed supernatant was pumped to the column and the flow was started at about $6 \mathrm{CV} / \mathrm{h}$. Some difficulties were encountered in stabilizing the flow during the early part of the run due to a bubble in the feed pump head. The flow rate, which was erratic, caused some fluctuations in the initial count rate for the effluent from the column. Once flow had been stabilized, 
the breakthrough curve returned to the level of background before starting the normal increase. Flow was continued until the effluent showed a ${ }^{137} \mathrm{Cs}$ level greater than $65 \%$ of the level in the feed. The column was then washed with water, drained, and prepared for counting and storage. The results of the run are shown in Fig. 11. It was predicted that this engineered form would perform somewhat better than the $-38 \mathrm{~B}$ material, although it was slightly less dense. The slope of the curve did decrease slightly after the lower-concentration cesium feed started passing through the column, beginning to approach the curves obtained at the lower total cesium concentration; however, the change was slight. The $50 \%$ breakthrough was at $294 \mathrm{CV}$, the $10 \%$ breakthrough at $127 \mathrm{CV}$, and the $1 \%$ breakthrough at about $61 \mathrm{CV}$. These results were about $3-10 \%$ better than those for the $-38 \mathrm{~B}$ material at the same breakthrough points. Because this CST is about $10 \%$ less dense than the $-38 \mathrm{~B}$ material, the performance per mass of sorbent is roughly $10-20 \%$ better.

No difficulties with the system were observed during operation. The samples obtained from the fraction collector yielded $\mathrm{pH}$ levels, by titration, of 13.93 for the first fraction, 13.96 for the second, 13.97 for the fifth $(120 \mathrm{CV})$, and 13.98 for the remaining samples of the run. The feed pH was 13.99. Even though the column had $1 \mathrm{~N} \mathrm{NaOH}$ in it at the start of the feeding of supernatant and had been pretreated with $1 N \mathrm{NaOH}$, the $\mathrm{pH}$ of the supernatant was still reduced by the CST as it passed through. (This is important to note if the supernatant contains any soluble aluminum, which could precipitate in and on the bed if the $\mathrm{pH}$ decreases even slightly.) There was no evidence of any aluminum precipitation during this run (and none was expected because of the low concentration of aluminum in the feed).

Calculations for the loading of the column, based on the ${ }^{137} \mathrm{Cs}$ in the feed and the volume of the feed, gave $37,441 \mu \mathrm{Ci}$ fed $(9.34 \mu \mathrm{Ci} / \mathrm{mL} \times 4008 \mathrm{~mL})$; analysis of the effluent from the column showed that $10,919 \mu \mathrm{Ci}$ had passed through the column. Counting of the column in its 3.2 -mm-thick stainless storage vessel after removal from the cell showed that $24,320 \mu \mathrm{Ci}$ was present, leaving about $2,201 \mu \mathrm{Ci}(5.9 \%$ of the cesium fed) unaccounted for.

\subsection{CST-0003, CsRD QUALIFICATION EXPERIMENT USING MVST W-29}

\subsubsection{Preparation of Column}

The ion-exchange column was prepared on the day that the run was initiated. The CST was delivered to Building 4501 in a $250-\mathrm{mL}$ plastic bottle labeled "Source Drum 2, Destination Drum 2, Type 
IONSIV IE-911, Lot 99909681003 , Treated to pH 12.6 with Caustic." The CST, in slurry form, was pipetted directly from the plastic bottle to the column. The column was labeled -CST5 on the glass and W29080896-2 on the blue plastic top. A total of $6.3 \mathrm{~cm}$ of CST was added to the column and tapped to the most settled position of $10.4 \mathrm{~mL}$. The packed bed was then fluidized to remove fines using a simulant that was $4.5 \mathrm{M}_{\text {in }} \mathrm{NaNO}_{3}$ and $0.1 \mathrm{~N}$ in NaOH . The initial flow, which was milky, left a significant quantity of fines in the catch bottle. A total of $100 \mathrm{~mL}$ of simulant was pumped through the column, and the bed was tapped to the most settled position of $6.3 \mathrm{~cm}$. Then the level of simulant was decreased to about $1 \mathrm{~cm}$ above the bed by allowing the simulant to pass downward through the bed, and the column was prepared for transfer to the cell after the top tubing connections had been added and the inlet and outlet tubes had been secured with pinch clamps. Fine solids $(0.3-0.5 \mathrm{~mL})$ were collected from the 10.4-mL column bed during washing with the simulant.

\subsubsection{Preparation of the System}

In preparation for the W-29 supernatant feed, the column flow system from the eluent tank to the fraction collector was completely rinsed after all flexible tubing had been replaced. In addition, the pump heads on the feed and column pump were replaced with new units, and the seals on the transfer pump were changed. All waste liquid and solids were removed from the cell to segregate W-27 waste (the previously used feed) from the W-29 waste that would be produced during the current operation. A leaking valve was replaced with a new valve. The special filter in a stainless steel filter holder for testing the W-29 supernatant for solids was also installed in place of one of the normal filters used for transferring feed to the tank. The filter holder contained a $25-\mu$-pore $304 \mathrm{~L}$ stainless steel filter mesh (Tetko, Inc., Briarcliff Manor, New York) and was pressure tested and supplied by Paul Taylor. ${ }^{17}$

Once the system was set up in the cell, a temporary, empty column was put in place, and the entire fluid pathway was rinsed with $100 \mathrm{~mL}$ of $0.5 \mathrm{NHNO}_{3}$, which was pumped from the eluent tank through the feed pump, the column, the column pump, the filter bypass, the detector, and the fraction collector drain. This rinse was followed successively with a $50-\mathrm{mL}$ distilled water (DI) flush and a $0.1 \mathrm{~N} \mathrm{NaOH}$ rinse using $10 \mathrm{~mL}$ of liquid. During the caustic rinse, valved V-12 (see Fig. 1) appeared to become plugged. To resolve this problem, another $100 \mathrm{~mL}$ of $0.1 \mathrm{NNaOH}$ was added to the eluent tank for rinsing. No flow of liquid could be obtained between the column and the column pump, so it was determined that V-12 
should be replaced before beginning the run. After V-12 had been replaced, V-10 was found to be the faulty valve, and since V-10 was not needed for this run (it is used during elution of regenerable resins), it was bypassed. This step resolved the flow problem in the system, so the remainder of the tubing was drained and the column containing the test CST sorbent was placed in the cell and attached to the system.

The feed bottle (W29080896-2) was prepared to pump supernatant to the system feed tank by opening the valves on the lid and setting the transfer valves so that liquid passed through the CsRD filter on its way to the feed tank. The supernatant was pumped at a flow rate of about $35-40 \mathrm{~mL} / \mathrm{min}$, using a FMI-type pump, with the filter upstream of the pump and a pressure/vacuum gauge on the line between the filter and the pump to measure the pressure drop across the filter. Transfer of the supernatant required about $60 \mathrm{~min}$, and the pressure drop across the filter was approximately $450-520 \mathrm{~mm} \mathrm{Hg}$ during most of the transfer. After transfer was complete, the lines were emptied by raising the bottle liquid pickup line above the liquid level and pumping air through the lines and filter to the feed tank. The valves were then reset, and the pump was rinsed with DI water and shut off.

The fraction collector was prepared by adding empty $250-\mathrm{mL}$ polypropylene, labeled bottles to the nine positions and setting the program for remote operation. It was expected that approximately $3 \mathrm{~h}$ of pumping through the column would put about $180 \mathrm{~mL}$ of treated supernatant in each bottle at the test design of about $1 \mathrm{~mL} / \mathrm{min}$. The in-line detector was also prepared to count the ${ }^{137} \mathrm{Cs}$ present in the column effluent. The channel number calibration was checked, and the cell background was determined.

\subsubsection{Conduct of CST Loading}

After all preparations had been completed, the feed pump and valves were configured to pump supernatant to the column and from the column through the filters and detector, and then to the fraction collector. As the feed entered the column and mixed with the simulant present above the bed, some turbidity was noted initially but it disappeared within the next several minutes. Also, after about 15 min of feeding, some brown specks could be seen on the top of the bed in the column. The flow rate was somewhat erratic during initial startup due to the lack of liquid in the lines (the pumps were pumping air) and a pressure that was too low to overcome the surface tension in the postcolumn filter. (Up to 15-20 psi was required to start initial liquid flow; however, after liquid filled the filter, the pressure drop 
returned to about 1 psi.) After about $3 \mathrm{CV}$, the rate was fairly stable; after $6 \mathrm{CV}$, very little variation occurred from flow check to flow check throughout the rest of the loading operation.

The cell detector data collection and the fraction collector were started after it had been determined that liquid had passed through the filter. No problems were encountered until about $7 \mathrm{~h}$ after the feed had been started. At this point, the feed pump did not get restarted after checking the flow rate of supernatant through the column. The flow rate was checked by increasing the pump rate of the feed pump, filling up the top part of the column with liquid, shutting off the feed pump, and then timing the fall of the liquid in the column by using the dimensional tape attached to the outside of the column. A fall of $2 \mathrm{~cm}$ during $3 \mathrm{~min} 10 \mathrm{~s}$ gave the desired flow rate. After the check, the feed pump was restarted at the normal flow rate. After the flow check at 11:30 p.m., the feed pump was accidentally not restarted and, as a result, the column was drained of liquid. After this error was discovered, the feed pump was restarted and the column was refilled with supernatant with the column pump turned off. The column pump was then restarted at its normal rate; however, the pressure drop caused by air in the effluent filter made it necessary to increase the pump rate slightly to compensate.

Once flow had been completely reestablished through the column, pump, and filter at the desired flow rate (the feed pump was set at the flow rate used previous to the problem, and the column pump was adjusted to match it during the air purging process), attempts were made to remove the air bubbles that had formed in the bed. The procedure involved reversing the pump flow momentarily (about $10 \mathrm{~s}$ ) in an effort to make the bubbles rise through the bed and exit via the vent. This sequence, which was repeated twice, did not fluidize the bed but did discharge several large and small bubbles. After the upset, the height of the settled bed was $6.4 \mathrm{~cm}$ instead of the original $6.3 \mathrm{~cm}$, but the $6.3-\mathrm{cm}$ level was used for CV calculations for the entire run. Although several small and very small bubbles remained visible in the bed, they gradually disappeared over the next several hours of feeding; the bed height did not change. Since the total flow was off for approximately $30-35 \mathrm{~min}$, this time was subtracted from the elapsed time of the run in the data analysis. The detector was watched carefully for indications of channeling or any other problems; however, none was noted. As a result, the run was continued and was completed uneventfully during the next $500 \mathrm{CV}$.

The loading was terminated by stopping the feed to the column, emptying the lines back to the feed tank, and adding $100 \mathrm{~mL}$ of simulant $\left(4.5 \mathrm{~N} \mathrm{NaNO}_{3}\right.$ and $\left.0.1 \mathrm{~N} \mathrm{NaOH}\right)$ to the eluent tank to rinse the supernatant out of the column and system. During the rinse, the detector counts did not decrease as 
expected once the simulant had passed through the column and traveled through the detector. Instead, the ${ }^{137} \mathrm{Cs}$ level remained relatively constant for more than $2 \mathrm{~h}\left(12^{+} \mathrm{CV}\right)$ during the simulant feeding. The $100 \mathrm{~mL}$ of simulant was not exhausted at the estimated time, and it was discovered that about $50 \mathrm{~mL}$ of $0.1 \mathrm{NNaOH}$ had been left in the tank during the prerun rinse. However, this made no difference during the simulant rinse because the $\mathrm{pH}$ of each solution $(0.1 \mathrm{~N} \mathrm{NaOH})$ was the same. Following the simulant rinse, the system was rinsed with DI water, and the detector counts decreased, as expected, from about $55 \%$ breakthrough level to about $5 \%$ breakthrough in about $1 \mathrm{~h}$. After the rinse indicated that the system had been cleared of supernatant, the column was drained for counting and transport purposes. The final reading on the detector showed that the level of ${ }^{137} \mathrm{Cs}$ in the column effluent was less than $1 \%$ after the column had been drained. The column was then isolated from the system, the inlet and outlet tubes were clamped, and the column was prepared for removal from the cell.

\subsubsection{Results of the W-29 Loading of the CST}

The run was continued until the ${ }^{137} \mathrm{Cs}$ breakthrough was greater than $50 \%$, as determined by comparing the concentration in column effluent sample $30(516 \mathrm{CV})$ with the feed concentration. The final breakthrough when the run was complete was greater than $55 \%$ at $560 \mathrm{CV}$. Following the run, samples were analyzed and the results were used to calibrate the cell detector and to make the final determination of the extent of loading.

Samples of the fractions that contained approximately $55 \mathrm{CV}$ were packaged for transfer to the CASD for chemical and radiological analyses. From these results (Table 6), comparisons of the calibrations could be made between the detector systems in Building 4501 and the loading ability of the CST for other metals could be ascertained. The loading curves for the qualification run are shown in Figs. 12-14.

The feed and effluent samples were analyzed for the elements of concern, including $\mathrm{Cs}, \mathrm{Al}, \mathrm{Hg}, \mathrm{Pb}$, $\mathrm{Ni}, \mathrm{Ag}, \mathrm{Ba}, \mathrm{Cd}, \mathrm{Se}, \mathrm{Cr}, \mathrm{Ag}, \mathrm{K}, \mathrm{Na}, \mathrm{Ca}, \mathrm{Si}$, and the radioactive isotopes ${ }^{134} \mathrm{Cs},{ }^{137} \mathrm{Cs},{ }^{60} \mathrm{Co},{ }^{90} \mathrm{Sr}, \mathrm{Pu},{ }^{99} \mathrm{Tc}$, ${ }^{106} \mathrm{Ru}$, and gross alpha and beta. The feed and two other samples were tested for nitrate, and the feed was checked for $\mathrm{pH}$. The analyses showed that the CST loaded $\mathrm{Ba}, \mathrm{Ca}, \mathrm{Cs}$, gross alpha and beta, ${ }^{90} \mathrm{Sr}, \mathrm{U}$, and $\mathrm{Zn}$. The $\mathrm{Hg}, \mathrm{Cd},{ }^{99} \mathrm{Tc}, \mathrm{Cr},{ }^{106} \mathrm{Ru}, \mathrm{Rb}, \mathrm{Ni}, \mathrm{Na}, \mathrm{K}$, and $\mathrm{Al}$ levels were essentially unchanged between feed and the effluents. The ${ }^{60} \mathrm{Co}$ level was almost constant in each of the effluents, but slightly lower than that of the feed, while the Si level was slightly higher than that of the feed for most samples. The ${ }^{137} \mathrm{Cs} /{ }^{134} \mathrm{Cs}$ and the 
Table 6. Analyses of feed and effluent samples

\begin{tabular}{|c|c|c|c|c|c|c|c|c|c|c|c|c|}
\hline Element & Feed & CST5-2 & CST5-5 & CST5-8 & CST5-11 & CST5-14 & CST5-17 & CST5-20 C & CST5-23 & CST5-26 & CST5-29 & CST5-32 \\
\hline Al, ppm & 4.17 & 5 & 3.33 & 4.23 & 4.27 & 4.29 & 3.83 & 3.88 & 3.86 & 3.96 & 4.02 & 3.82 \\
\hline As, ppm & $<2.5 E-1$ & & & & & 0.31 & & & & & & \\
\hline $\mathrm{Ba}, \mathrm{ppm}$ & 0.865 & 0.035 & & & & & & & & & & \\
\hline $\mathrm{Ca}, \mathrm{ppm}$ & 1.42 & 0.44 & 1.88 & 0.31 & 0.315 & 0.355 & 0.215 & 0.245 & 0.26 & 0.28 & 0.295 & 0.255 \\
\hline Cd-ppm & 0.24 & 0.215 & 0.55 & 0.195 & 0.24 & 0.275 & 0.225 & 0.22 & 0.25 & 0.235 & 0.26 & 0.235 \\
\hline${ }^{60} \mathrm{Co}, \mathrm{Bq} / \mathrm{mL}$ & 500 & 410 & 410 & 410 & 450 & 410 & 430 & 410 & 420 & 420 & 410 & 440 \\
\hline $\mathrm{Cr}, \mathrm{ppm}$ & 3.44 & 3.41 & 3.93 & 3.36 & 3.37 & 3.39 & 3.18 & 3.18 & 3.24 & 3.27 & 3.19 & 3.25 \\
\hline Cs, ppm & 0.58 & & 0.003 & 0.01 & 0.03 & 0.034 & 0.113 & 0.165 & 0.206 & 0.249 & 0.291 & 0.329 \\
\hline${ }^{134} \mathrm{Cs}, \mathrm{Bq} / \mathrm{mL}$ & 7,600 & & 14 & 110 & 380 & 790 & 1,300 & 1,900 & 2,400 & 3,000 & 3,400 & 3,900 \\
\hline${ }^{137} \mathrm{Cs}, \mathrm{Bq} / \mathrm{mL}$ & 460,000 & 11 & 910 & 6,600 & 22,000 & 47,000 & 80,000 & 100000 & 150,000 & 180,000 & 210,000 & 230,000 \\
\hline Gross alpha, Bq/mL & 30 & & & & & 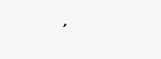 & & & & & & 26 \\
\hline Gross beta, $\mathrm{Bq} / \mathrm{mL}$ & 550,000 & 1,400 & 2,400 & 9,200 & 28,000 & 57,000 & 96,000 & 100000 & 180,000 & 220,000 & 240,000 & 270,000 \\
\hline $\mathrm{Hg}, \mathrm{ppm}$ & 0.258 & 0.219 & 0.21 & 0.233 & 0.223 & 0.237 & 0.249 & 0.234 & 0.229 & 0.23 & 0.228 & 0.223 \\
\hline $\mathrm{K}, \mathrm{ppm}$ & 14,700 & 14,600 & 14,800 & 14,800 & 14,300 & 14,600 & 14,700 & 14,600 & 14,500 & 14,400 & 14,400 & 14,400 \\
\hline $\mathrm{Na}, \mathrm{ppm}$ & 95,400 & 95,600 & 96,200 & 96,100 & 93,300 & 95,100 & 95,500 & 95,000 & 93,900 & 93,900 & 93,900 & 94,200 \\
\hline $\mathrm{Ni}, \mathrm{ppm}$ & 1.04 & 1 & & 0.985 & 1 & 1.03 & 0.895 & 0.975 & 0.94 & 1.02 & 0.93 & 0.94 \\
\hline $\mathrm{Pb}, \mathrm{ppm}$ & 2.89 & & & 0.04 & 0.03 & 0.047 & 0.0685 & 0.085 & 0.105 & 0.137 & 0.165 & 0.201 \\
\hline${ }^{240} \mathrm{Pu}$ decay, $\mathrm{Bq} / \mathrm{mL}$ & $<4.2$ & & & 6.5 & 4.6 & & & & 4.6 & 7.4 & 24.6 & \\
\hline${ }^{240} \mathrm{Pu}$ mass, ppm & $<.001$ & & & 0.001 & 0.001 & & & & 0.001 & 0.001 & 0.003 & \\
\hline $\mathrm{Rb}, \mathrm{ppm}$ & 1.28 & 0.585 & 1.22 & 1.28 & 1.25 & 1.29 & 1.27 & 1.06 & 1.03 & 1.01 & 1.2 & 1.16 \\
\hline${ }^{106} \mathrm{Ru}, \mathrm{Bq} / \mathrm{mL}$ & & 110 & 120 & 140 & & & & & & & & \\
\hline $\mathrm{Si}, \mathrm{ppm}$ & 44.1 & 52.3 & 29.1 & 44.8 & 51.4 & 53.9 & 68.9 & 56.8 & 55.6 & 53.4 & 52.6 & 53.4 \\
\hline${ }^{99} \mathrm{Tc}$ decay, $\mathrm{Bq} / \mathrm{mL}$ & 342 & 335 & 322 & 340 & 321 & 322 & 333 & 342 & 318 & 324 & 316 & 329 \\
\hline${ }^{99} \mathrm{Tc}$ mass, ppm & 0.545 & 0.533 & 0.513 & 0.541 & 0.51 & 0.512 & 0.53 & 0.543 & 0.505 & 0.516 & 0.502 & 0.524 \\
\hline Total rad. Sr, Bq/mL & 4,100 & 19 & 31 & 160 & 150 & 900 & 220 & 720 & 360 & 520 & 1,500 & 1,500 \\
\hline$U, \mathrm{ppm}$ & 13.3 & & & 0.76 & 1.68 & 3.41 & 4.18 & 5.51 & 6.2 & 7.13 & 7.31 & 8.19 \\
\hline $\mathrm{Zn}, \mathrm{ppm}$ & 1.35 & & & & & & & & & & 0.22 & 0.3 \\
\hline \multicolumn{2}{|c|}{ Curies loaded per $1.1-\mathrm{ft}^{3} \mathrm{CST}$ column } & 10.27 & 30.68 & 51.41 & 71.15 & 89.95 & 107.43 & 123.11 . & 136.36 & 149.28 & 156.02 & 165.72 \\
\hline IPA7764 & CV for sample & 26.3 & 80.5 & 135.2 & 189.9 & 244.6 & 298.8 & 353.3 & 408.0 & 462.5 & 498.5 & 550.2 \\
\hline
\end{tabular}


ORNL DWG 97C-362

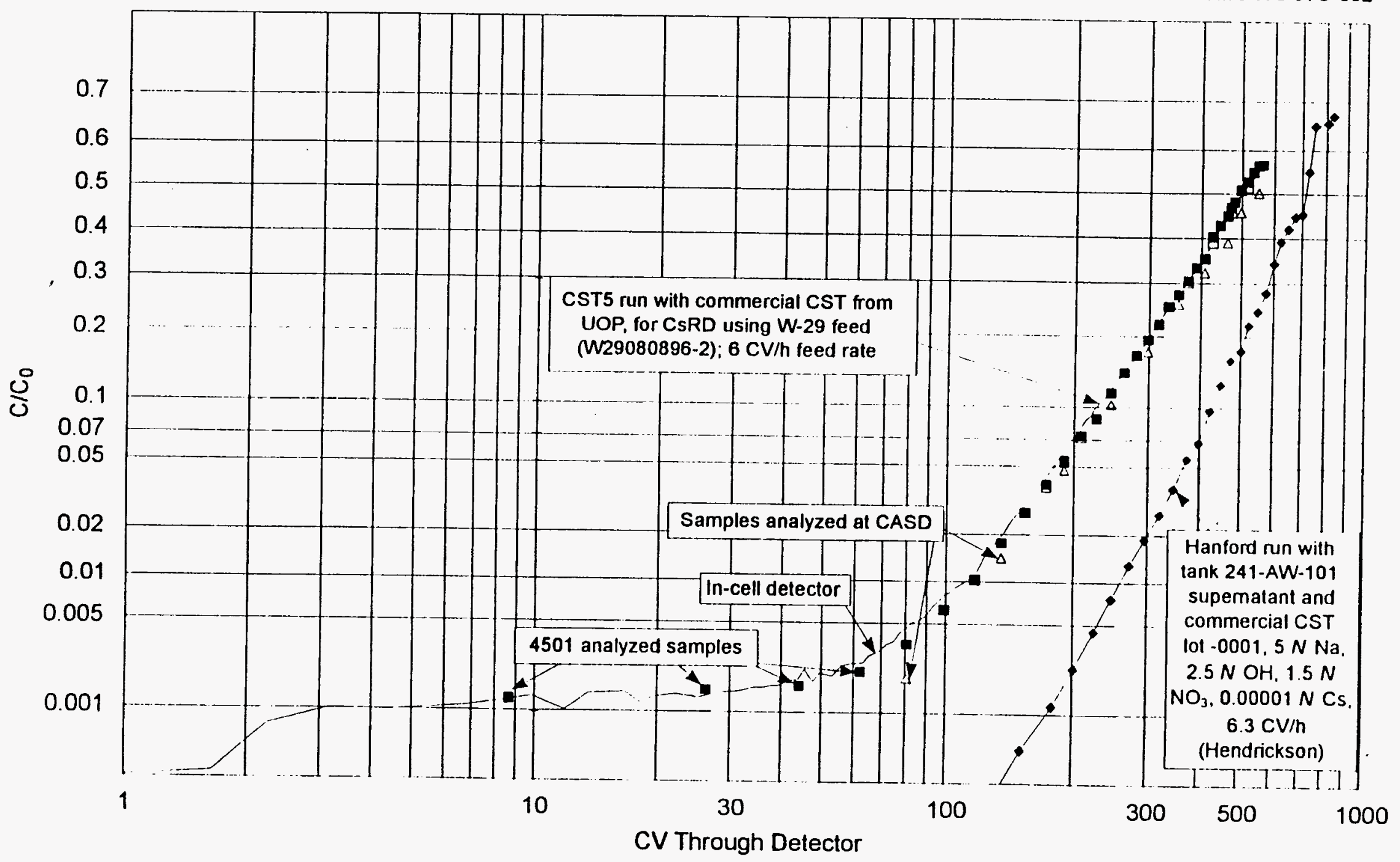

Fig. 12. Loading curve for CST (lot -0003) at 6 CV/h (August 12-16, 1996), using commercial CST and W-29 feed. 
ORNL DWG 97C-363

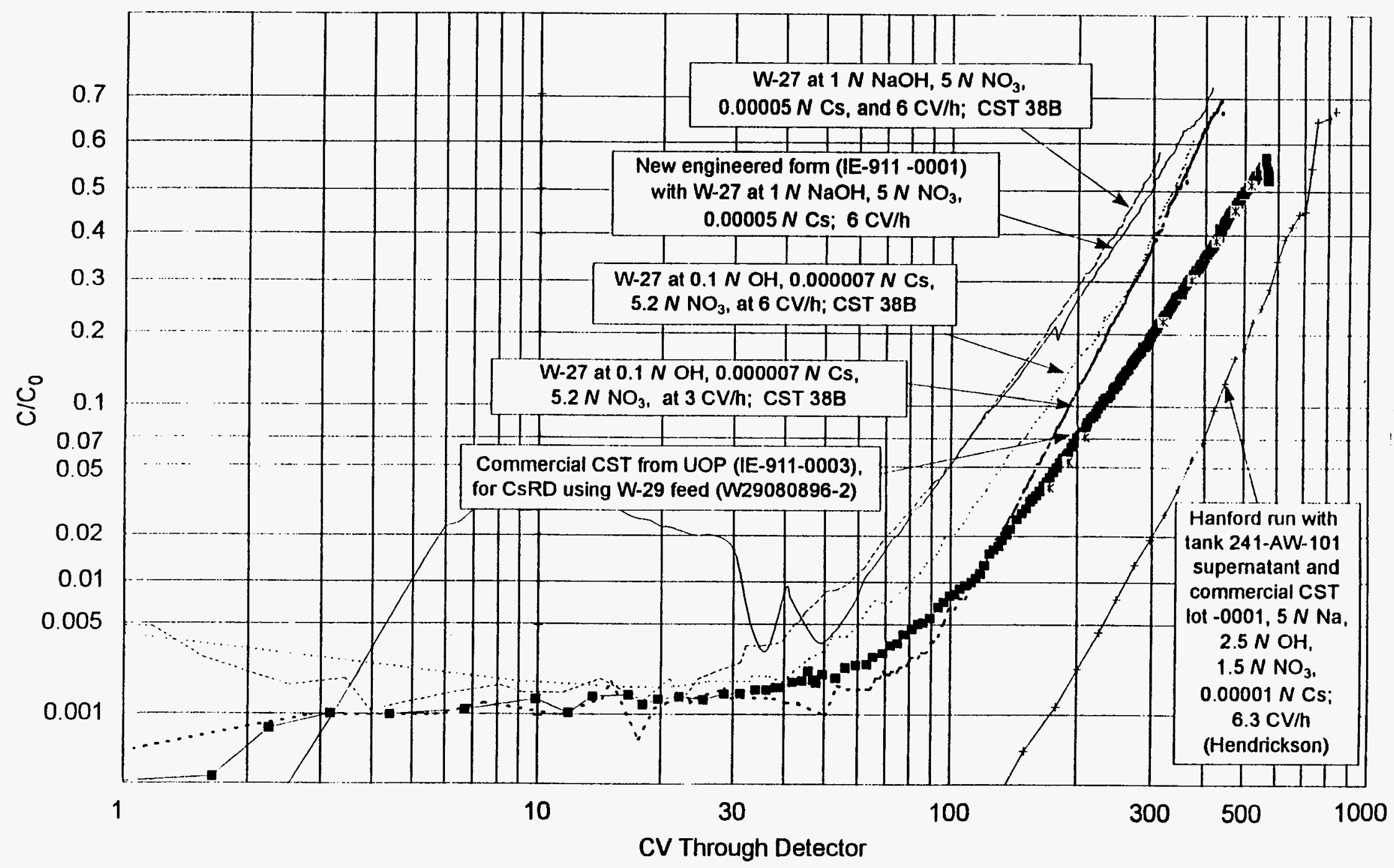

Fig. 13. Comparison of the loadings of the CST (-38B, -0001, and -0003) materials, using W-27 and W-29 supernatants. 


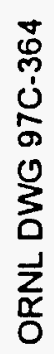

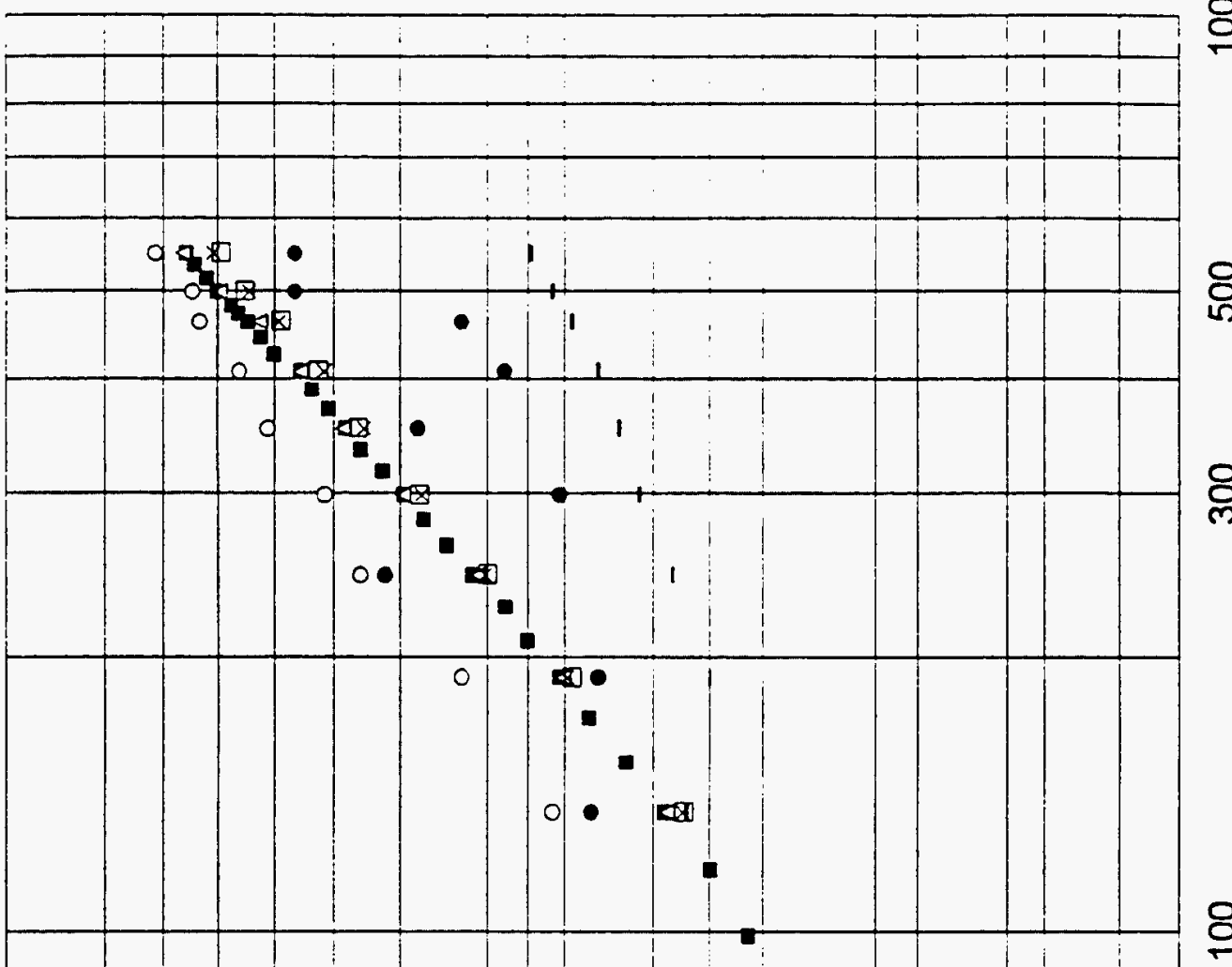

용

8

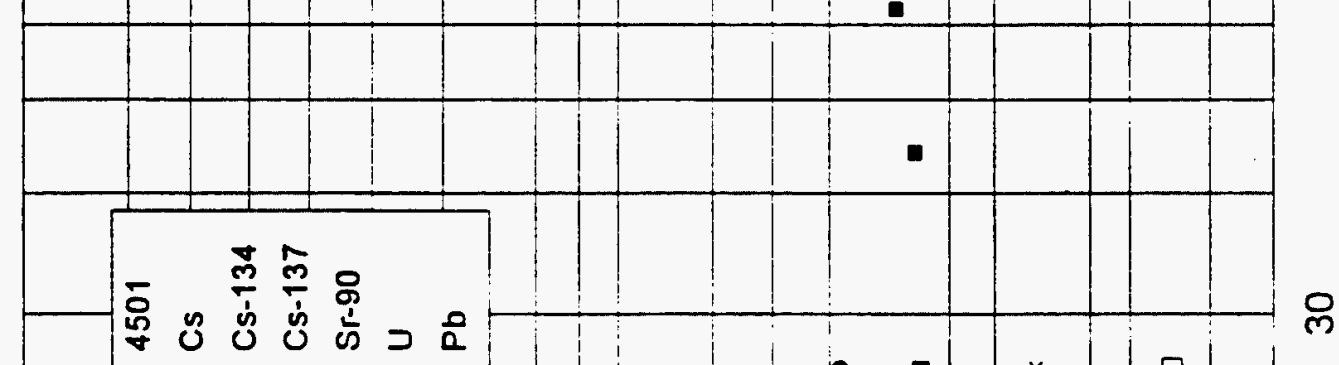

음

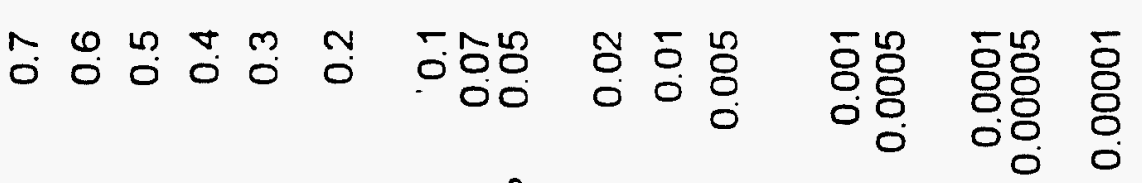


${ }^{137} \mathrm{Cs} /$ total Cs ratios were also almost constant for all samples except the earliest ones (which had very low Cs concentrations). Plutonium was found in some of the later samples.

Curves for the ${ }^{137} \mathrm{Cs}$ samples and the cell detector output give about the same column volumes at $50 \%$ breakthrough, as shown in Figs. 12-14. The samples analyzed by CASD gave breakthroughs at $550 \mathrm{CV}$ of $56.7,51$, and $50 \%$ for ${ }^{134} \mathrm{Cs},{ }^{137} \mathrm{Cs}$, and total $\mathrm{Cs}$, respectively. These values show good agreement, given the error bars on the measurements of $\pm 2-4 \%$. Least-squares fits on the log probability plots for the different cesium analyses give $50 \%$ breakthroughs of $503.7 \mathrm{CV}$ for the Building 4501 analyses using the germanium detector on the samples, $506.65 \mathrm{CV}$ for the analyses using the cell detector, $507 \mathrm{CV}$ for the CASD total cesium analyses, $546.75 \mathrm{CV}$ for the CASD ${ }^{134} \mathrm{Cs}$ analyses, and $546.2 \mathrm{CV}$ for the CASD ${ }^{137} \mathrm{Cs}$ analyses. The main difference between the Building 4501 samples counting and the CASD sample counting was in the values of the ${ }^{137} \mathrm{Cs}$ concentrations of the feed. The CASD values were slightly higher, thus giving a $\mathrm{C} / \mathrm{C}_{0}$ value that was lower for CASD measurements.

The in-line detector and sample data are also plotted in Fig. 13 for comparison with data from previous CST runs that used W-27 feed at both $\mathrm{pH} 13.3$ and 14 (with extra cold cesium). The CV to 50\% breakthrough for the W-29 feed is significantly greater than any of the others. The primary differences in the feed analyses besides the cesium concentration are the pH level (W-29, 12.6; W-27, 13.3 and 14.0), the potassium concentration (W-29, 0.37 M; W-27, 0.26-0.3 M), and the nitrate concentration (W-29, 4.0 M; $\mathrm{W}-27,4.8-5.2 M$. These differences are significant and seem to indicate that the CST is both $\mathrm{pH}$ and nitrate dependent. Studies made with simulants had shown only a slightly greater decrease in the $\mathrm{K}_{\mathrm{d}}$ when $0.5 \mathrm{~mol}$ of $\mathrm{KNO}_{3}$ was added, as compared with adding $0.5 \mathrm{~mol}$ of $\mathrm{NaNO}_{3}$. (This amounted to a $200 \%$ increase in $\mathrm{K}$ but only an $11 \%$ increase in $\mathrm{Na}$.) The total $\mathrm{Cs}$ in W-29 was lower, $0.58 \mathrm{ppm}$ vs $0.98 \mathrm{ppm}$ (9.95 ppm with added cesium), for a total cesium reduction of about $40 \%$. The increase in CV to $50 \%$ for the comparable CST runs was about 345 to $505 \mathrm{CV}$, or $45 \%$. Since the previous runs using increased cesium had not shown this much dependence, the $\mathrm{pH}$, nitrate, and cesium levels are apparently all involved in the increase.

The other materials that exhibited apparent loadings were plotted in Fig. 14, along with the ${ }^{137} \mathrm{Cs}$ analyzed at CASD and both ${ }^{137} \mathrm{Cs}$ and ${ }^{134} \mathrm{Cs}$ analyzed in Building 4501 facilities. The plots show that the divalent cations, $\mathrm{Pb}$ and ${ }^{90} \mathrm{Sr}$, exhibited loading curves, while $\mathrm{Ba}$ and $\mathrm{Zn}$ did not show up in the effluent samples until the last fraction or two. Good curves were developed for $\mathrm{U}, \mathrm{Pb}$, and ${ }^{90} \mathrm{Sr}$, although the ${ }^{90} \mathrm{Sr}$ curve was erratic. The apparent breakthroughs for the $\mathrm{U},{ }^{90} \mathrm{Sr}$, and $\mathrm{Pb}$ were 433, 1164, and $3327 \mathrm{CV}$, respectively. 
Sorbent from the loaded column was subjected to a modified TCLP procedure performed by Babcock \& Wilcox, Research and Development Division (Lynchburg, VA). The results showed levels of As $<0.16 \mathrm{mg} / \mathrm{L}, \mathrm{Ba}=1.8 \mathrm{mg} / \mathrm{L}, \mathrm{Cd}<0.02 \mathrm{mg} / \mathrm{L}, \mathrm{Cr}<0.05 \mathrm{mg} / \mathrm{L}, \mathrm{Pb}<0.29 \mathrm{mg} / \mathrm{L}, \mathrm{Hg}<0.002 \mathrm{mg} / \mathrm{L}, \mathrm{Se}=$ $0.31 \mathrm{mg} / \mathrm{L}$, and $\mathrm{Ag}<0.07 \mathrm{mg} / \mathrm{L}$ in the leach liquid - all of which were below the regulatory limits.

\subsection{RF COLUMN TEST USING AEA RF AND W-27 SUPERNATANT}

An experiment was completed using RF resin obtained from AEA (AEA batch) in which the feed rate through the bed was $3.5 \mathrm{CV} / \mathrm{h}$. Three previous experiments were completed with resin obtained from Bibler and supernatant at $0.1 \mathrm{~N}$ hydroxide concentration. ${ }^{13}$ For this run, $5.413 \mathrm{~g}$ of resin (tapped volume, $6.2 \mathrm{~cm}^{3}$ ) was treated with $10 \mathrm{CV}$ of $0.5 \mathrm{MHNO}_{3}$. The first $2 \mathrm{CV}$ of acid released a significant quantity of gas from the resin. The liquid leaving the resin initially had an amber color, which gradually decreased during the acid feed. Fluffy white particles formed on the top of the bed and were removed by pipette. The bed had a height of $4.6 \mathrm{~cm}$ following acid treatment. The acid was followed by $7 \mathrm{CV}$ of DI water. During this treatment, the bed volume stayed at $4.6 \mathrm{~cm}$. The bed was then treated with $1 \mathrm{MNaOH}$ for $10 \mathrm{CV}$ at the expanded volume of resin and rinsed with DI water for $3 \mathrm{CV}$. The resin expanded to $10.3 \mathrm{~cm}^{3}$ during caustic treatment. The column was filled with a surrogate salt solution of $4.5 \mathrm{~N} \mathrm{NaNO}_{3}$ and $0.1 \mathrm{~N} \mathrm{NaOH}$ in preparation for loading.

The column was installed as described above. Supernatant feed (the original W-27 adjusted to 13.2-13.3 used in the first tests) was started through the bed at $6 \mathrm{CV} / \mathrm{h}$. Once feed was started through the bed, the effluent had a brown color that lasted for 2 to $3 \mathrm{CV}$. The height of the bed increased to $6.2 \mathrm{~cm}$ during the run. The loading was continued through $75 \mathrm{CV}$, with the breakthrough only reaching about 1.1-1.2\%. The loading curve, shown in Fig. 15, demonstrates that the initial breakthrough did not occur until $15 \mathrm{CV}$ and then the curve was very shallow to $1 \%$ at about $65 \mathrm{CV}$. The curve for CST batch $-38 \mathrm{~B}$ using the same feed is also plotted, and the two curves for the RF and CST are very close together. Following the loading, the column was rinsed with several CV of DI water, drained, and then removed to storage. 


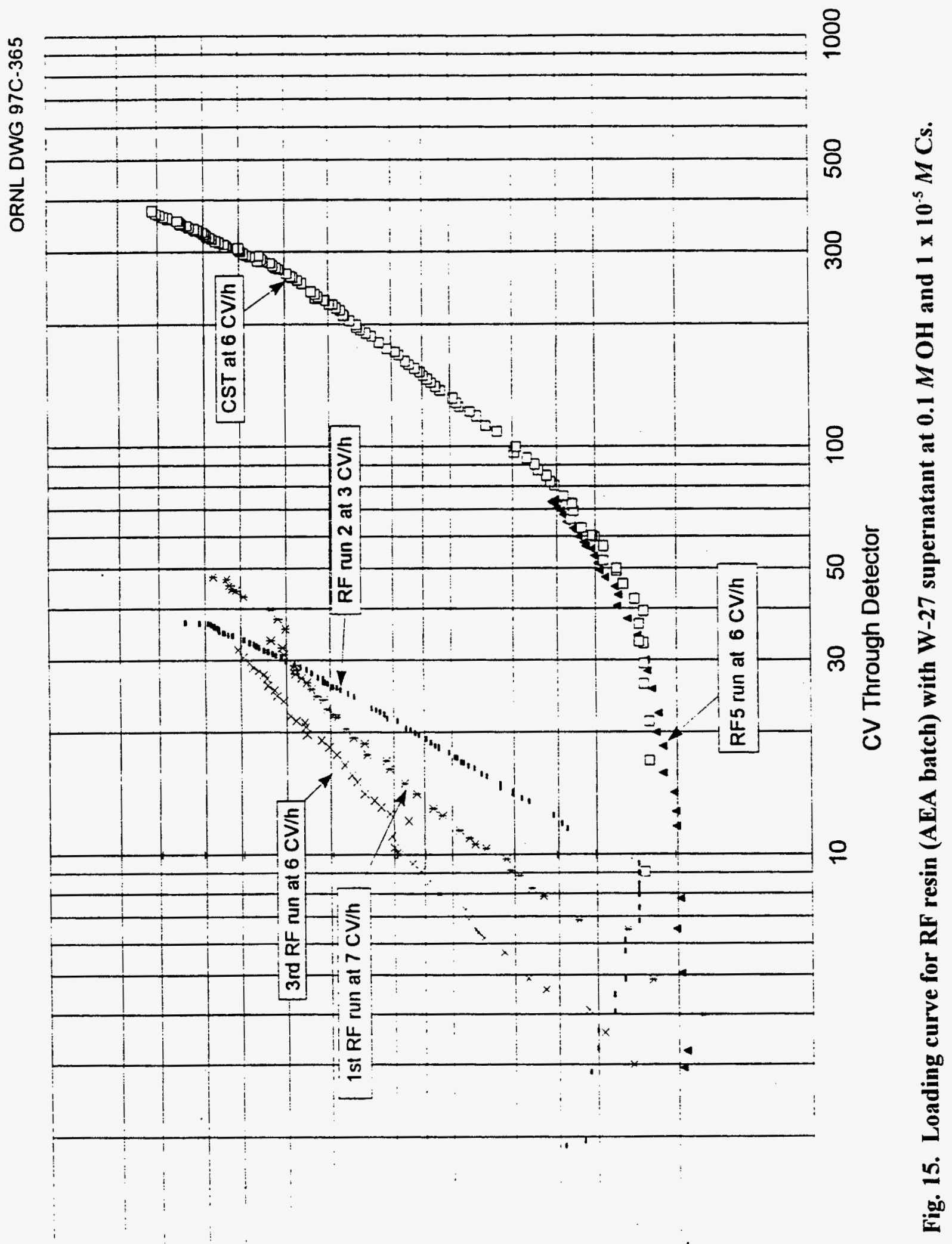

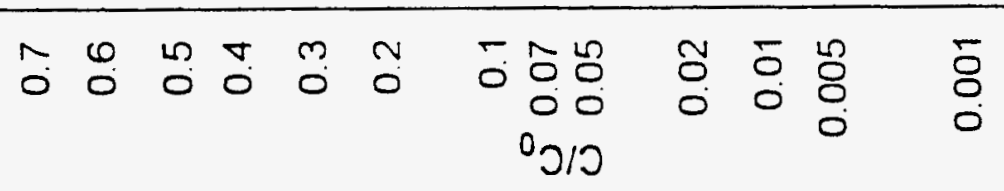




\subsection{AEA EIX TEST RESULTS}

\subsubsection{First Loading and EIX Elution of Test Cell 1}

The EIX rig was placed in the hot cell after the test cells had been filled with conditioned RF resin, and all tubing, electrical connections, and power supply cables were attached and tested. Then about $1900 \mathrm{~mL}$ of W-27 supernatant was pumped from the storage tank to the hot-cell feed tank through a $0.45-\mu \mathrm{m}$ filter. Because the first filter was plugged at the start of pumping, the second filter was used. When the tank was full, the lines were emptied and the pump rinsed. Next, the EIX rig feed tank was filled with $1100 \mathrm{~mL}$ of supernatant using the column feed pump of the hot-cell experiment.

The system was readied for operation by filling tank B with $250 \mathrm{~mL}$ of DI water to check the flow through the EIX cells. Water was pumped to the bubble traps of both cells and then allowed to flow through the EIX cells. When water left the cells, color could be seen in the exit tubing. The system was readied by placing sample bottles in the fraction collector to collect the effluent from the column after it had passed through the detector. The feed pump was then started at the rate of about $6.6 \mathrm{CV} / \mathrm{h}$ to load the cell resin with cesium. The feed was allowed to flow for $16 \mathrm{~h}$, or about $106 \mathrm{CV}$. At this point, the cesium breakthrough was about $1-2 \%$ as measured by the in-line detector. Then, the lines were emptied back to the feed tank, and DI water was pumped to the bubble trap to rinse the cell and reduce the conductivity to prepare for the elution. The loading curve is shown in Fig. 16.

The electrochemical elution was begun by first filling the catholyte tank with $250 \mathrm{~mL}$ of $0.1 \mathrm{M} \mathrm{NaOH}$ and the anolyte tank with $250 \mathrm{~mL} 0.1 \mathrm{NHNO}_{3}$. Next, the solutions were pumped through the cell chambers and tubing at $800 \mathrm{~mL} / \mathrm{h}$ for the duration of the elution. The power supply was set at $150 \mathrm{~mA}$, which resulted in a voltage of about $20 \mathrm{~V}$ when the power was directed to the cell. During the elution, the voltage increased up to the maximum setting of $60 \mathrm{~V}$ over a 30-min period and then the current gradually dropped to about $40 \mathrm{~mA}$. After $5 \mathrm{~h}$, the elution was discontinued and the lines were emptied back to their tanks (Fig. 17). The 5-h period was based on the results of simulant studies performed at AEA, where it was determined that complete elution should be accomplished during that time. The system was then prepared for the loading of cesium onto the resin again by passing $25 \mathrm{~mL}$ of $1 \mathrm{M} \mathrm{NaOH}$ through the cell resin. 


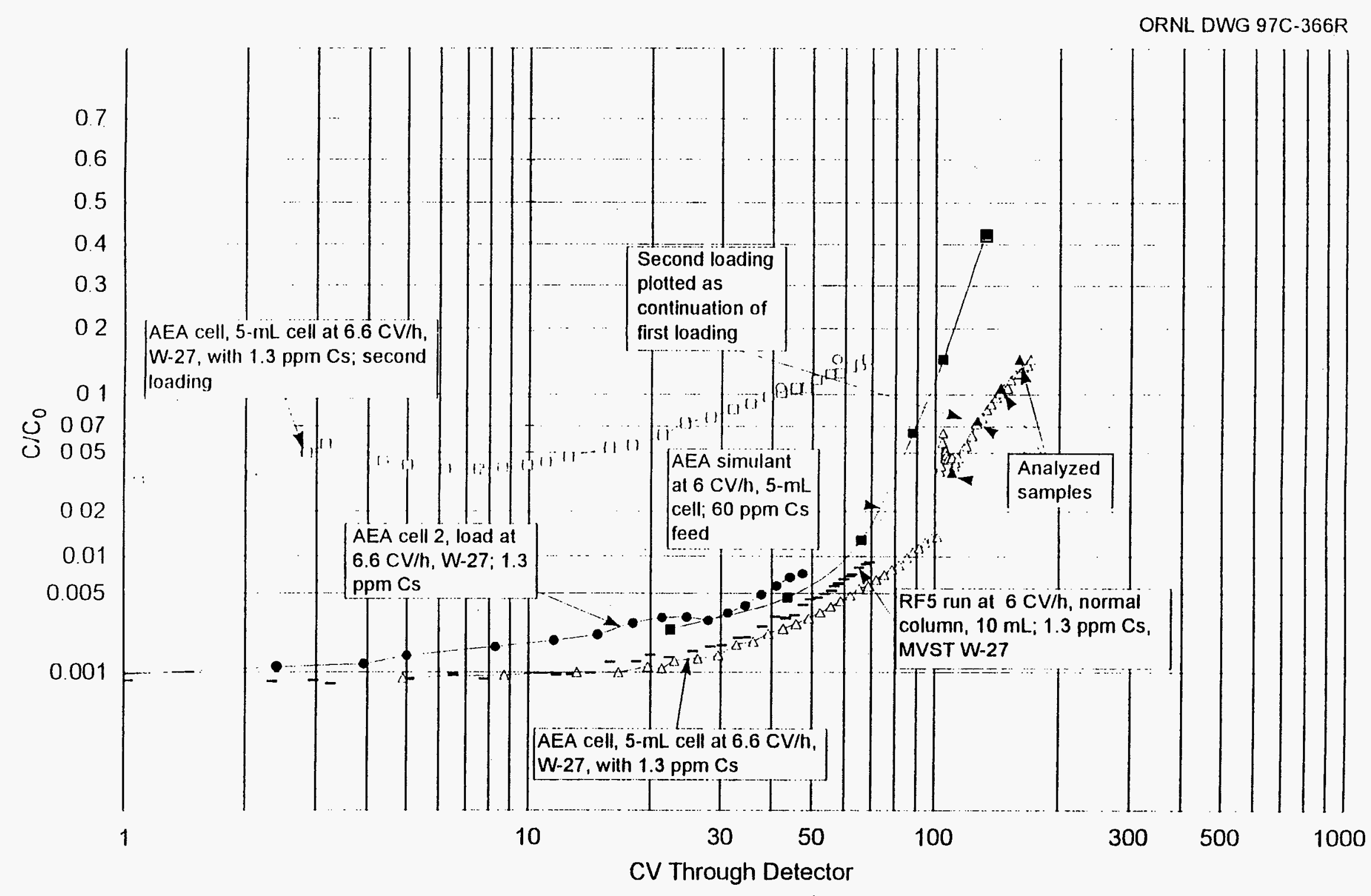

Fig. 16. Loading curves for the AEA EIX test cells, using RF resin and W-27 supernatant at $6.6 \mathrm{CV} / \mathrm{h}$. 
0
0
0
0
0
$\vdots$
0
$\vdots$
$\vdots$
0 ( $\forall \omega)$ luəsun
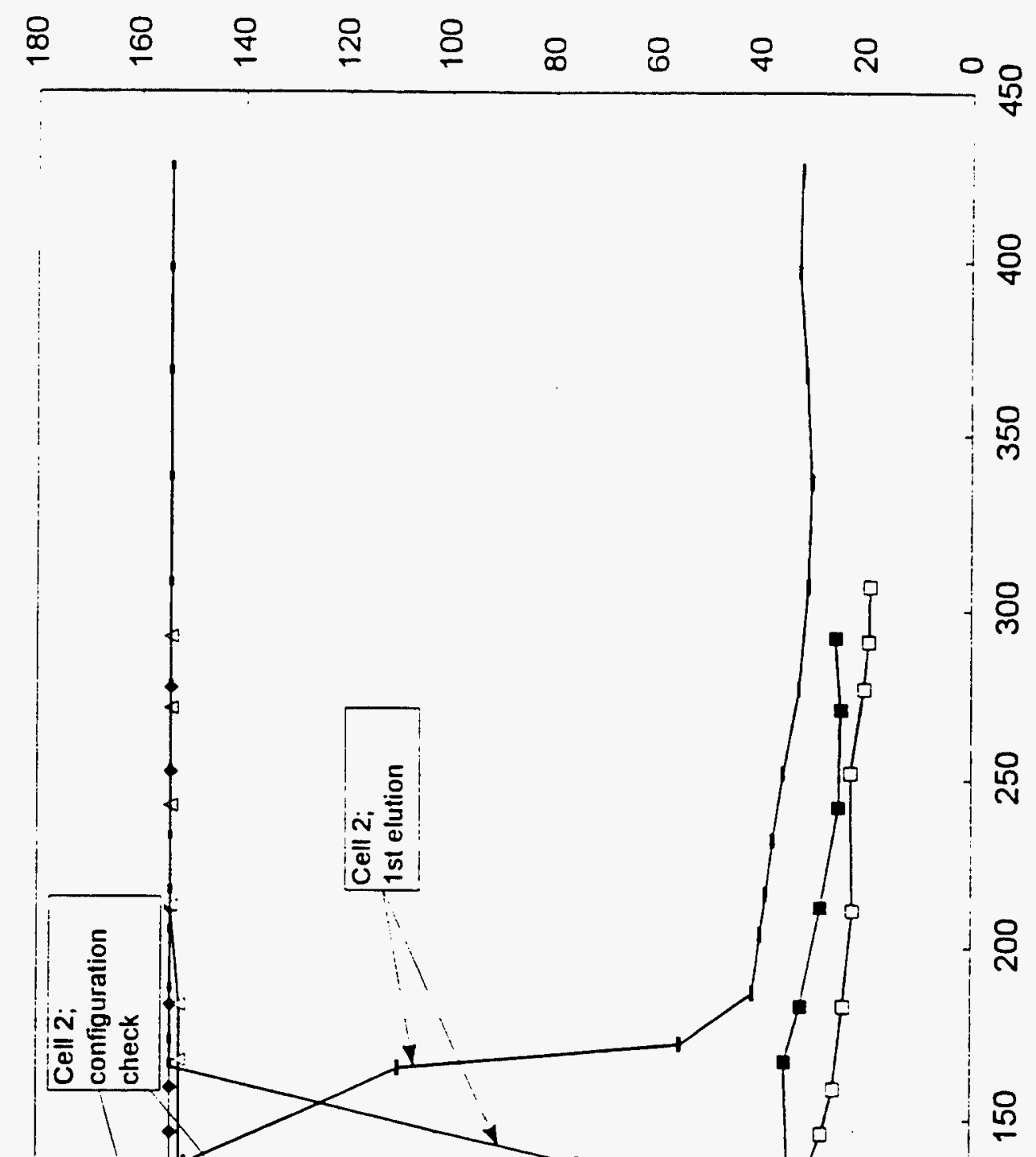

远
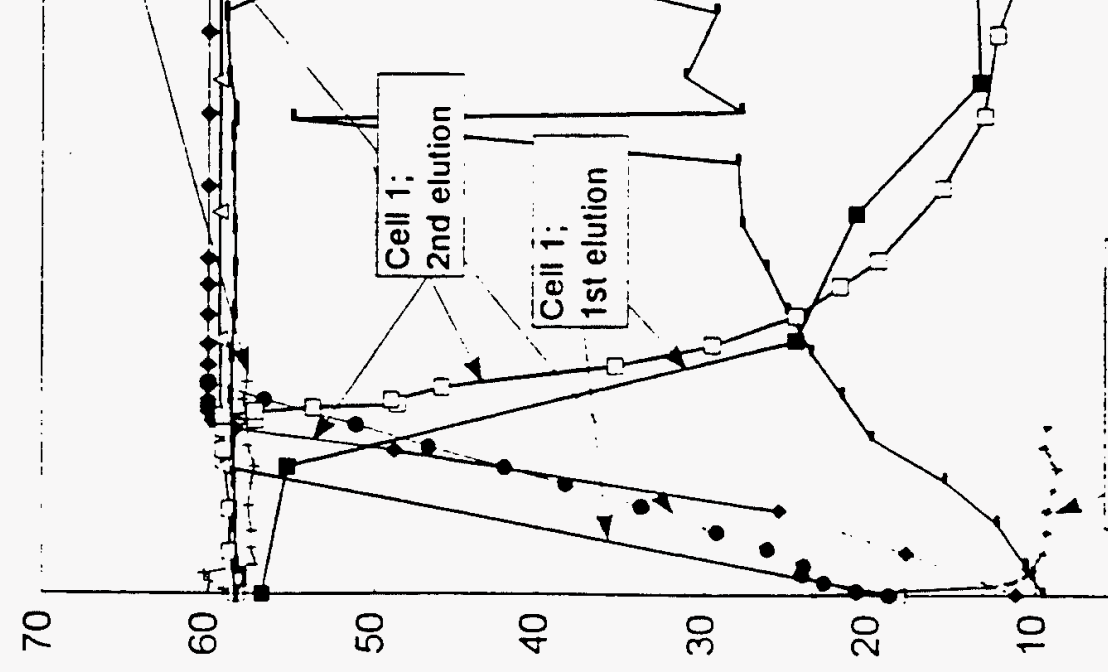

유

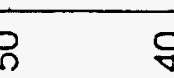

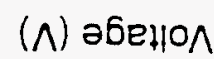




\subsubsection{Second Loading and EIX Elution of Test Cell 1}

The first loading-and-elution sequence was followed by the next batch of W-27 feed. When the feed material reached the detector after passing through the resin, the cesium level was higher than before the elution (Fig. 16). This suggested that either the resin had developed a channel or it had not been eluted. After determining that the catholyte did not contain the expected amount of cesium when it was analyzed, the decision was made to proceed with loading the resin for about 60-70 CV and then attempt electrochemical elution again. The second loading curve is plotted both individually and as a continuation of the first curve. The cesium breakthrough after the loading was about $15 \%$.

The second elution was started after the cell had been rinsed with $20 \mathrm{~mL}$ of DI water and the catholyte tank filled with $250 \mathrm{~mL}$ of fresh $0.1 \mathrm{MNaOH}$. This elution followed the same course as the first attempt; the only difference was that the current stayed at $150 \mathrm{~mA}$ for a slightly longer period (Fig. 17). Again, the elution was carried out for $5 \mathrm{~h}$ before termination. When the catholyte had been emptied and sampled, it was again found that very little cesium had been eluted. A test was then made to check the elution system by putting $0.1 \mathrm{MHNO}_{3}$ in the catholyte tank instead of the $\mathrm{NaOH}$. The current was reapplied to the cell for about $1 \mathrm{~h}$. The catholyte was then drained and the resin analyzed. Again, very little cesium had been eluted from the resin.

In order to ensure that the cells were installed correctly with the correct membranes, cell 2 was readied for an elution with $0.1 \mathrm{MHNO}_{3}$ as the anolyte and $0.01 \mathrm{NHNO}_{3}$ as the catholyte. The catholyte system was rinsed with DI water before the start. If the cell was installed correctly, then the $0.01 M$ acid would be neutralized during the application of electric current. The cell was operated as before, and the catholyte was then removed after the elution was complete. When the catholyte was sampled, the pH level had increased to greater than 7 ; therefore, it was concluded that the cell was correctly configured.

\subsubsection{First Loading and EIX Elution of Test Cell 2}

Based on the knowledge that the cell was configured correctly, cell 2 was prepared for loading with about 45-50 CV of W-27 supernatant to try the elution again. This time, the plan was to pass the catholyte through the cesium detection circuit during the elution. To do this, the line was broken downstream of the catholyte pump and routed through the detector and then back through the cell to the catholyte tank. With 
this arrangement, the Cs removal from the resin could be monitored and the elution continued if the results were favorable.

The second elution was run in the same manner as that described previously, and the current started at $150 \mathrm{~mA}$. Throughout the first $5 \mathrm{~h}$, very small amounts of $\mathrm{Cs}$ began to enter the catholyte stream and the Cs level gradually increased. After the increase was noted (Fig. 18), the decision was made to continue the elution to determine whether the Cs would eventually be removed. After the first $5 \mathrm{~h}$, a curve of the Cs content in the catholyte vs time began to increase sharply and finally reached a level near the projected feed level. When the curve "flattened out," the elution was stopped and the catholyte was pumped back to the catholyte tank and then sampled. As the cell detector indicated, the level of $\mathrm{Cs}$ in the catholyte was about $85 \%$ of that predicted for the volumes used if all the Cs was eluted. In addition, the bed level decreased slightly, which is the expected result for resin converted to the hydrogen form from the sodium form.

In order to check the extent of elution, the bed was next subjected to a normal acid elution by passing $0.5 \mathrm{~N} \mathrm{HNO}_{3}$ through the bed and collecting the effluent for counting analyses. The results showed that about $10 \%$ of the cesium loaded was recovered during the acid elution and another $85 \%$ was recovered during the EIX elution.

\subsubsection{Third EIX Elution of Test Cell 1}

Based on the success of eluting cell 2, cell 1 was set up for continuation of the EIX elution (where it had been left after the previous attempts). Nothing had been changed or passed through the resin since the first attempted EIX elution. This time, by passing catholyte through the detector, Cs could be seen coming off the resin at an increasing rate during the elution (Fig. 18). The elution was continued for several hours, and then the solutions were pumped back to their tanks; the elution was restarted the following day. During the first day, the detector counts rose from several hundred to well over 20,000 (more than twice the initial feed concentration). The elution was continued the next day, but very little additional $C s$ was eluted. The results showed that the EIX elution had removed about $90 \%$ of the loaded Cs. 
ORNL DWG 97C-368

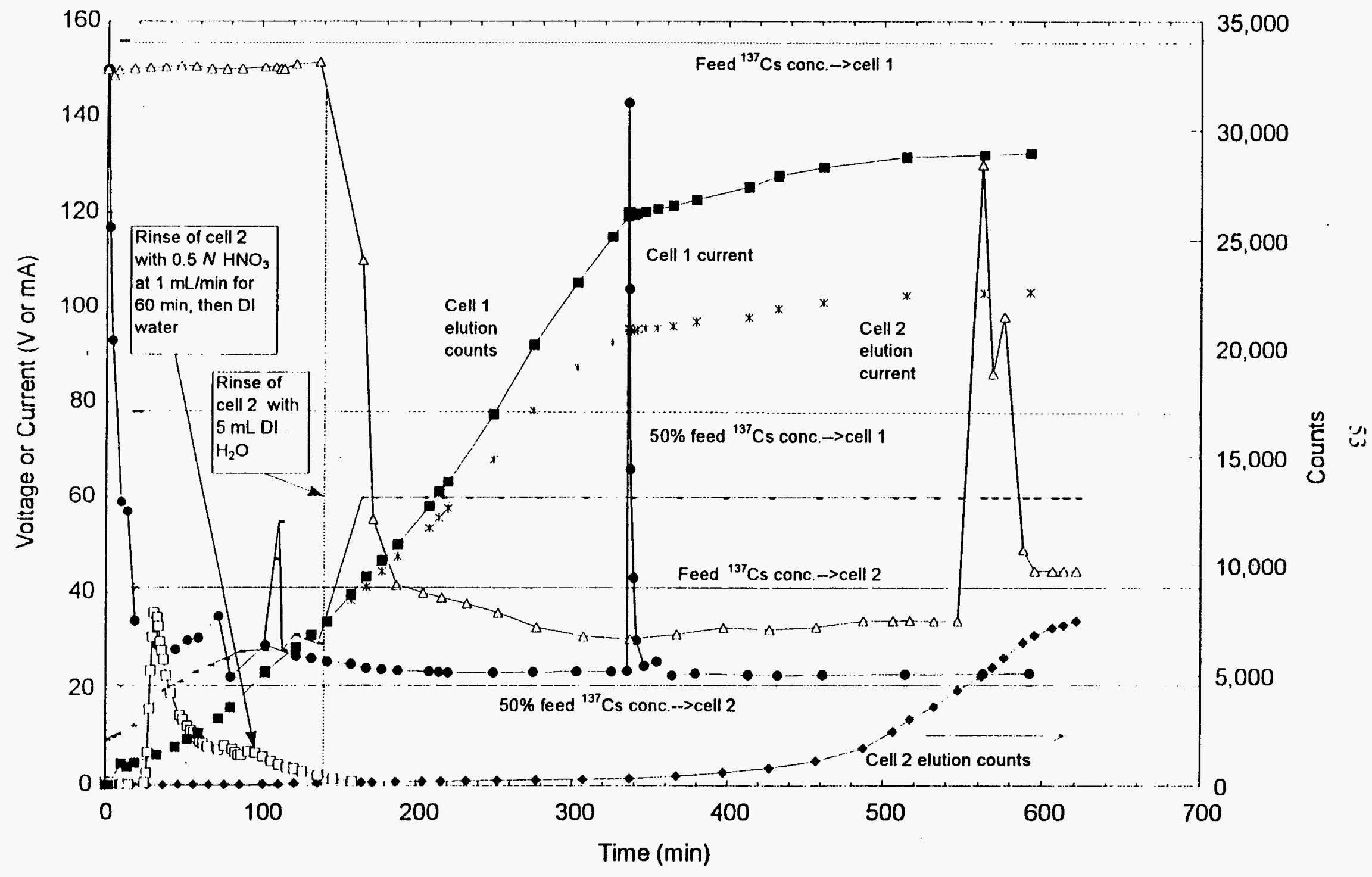

Fig. 18. Cesium results for the electrochemical elutions of the EIX cells. 


\section{DISCUSSION OF CONTINUOUS COLUMN RUNS}

\subsection{COMPARISON OF THE CONTINUOUS RUNS WITH BATCH EXPERIMENTS}

Many of the materials tested in the continuous system had been examined in batch studies using both actual supernatant and surrogate materials. Batch studies were done at PNNL on SuperLig ${ }^{\circledast} 644$ and RF ion-exchange materials for comparison with the same materials in column tests. ${ }^{8}$ Based on the batch studies, the SuperLig ${ }^{\circledR} 644$ and $R F$ materials had $K_{d}$ values of 1340 and $620 \mathrm{~mL} / \mathrm{g}$, respectively. $\mathrm{K}_{\mathrm{d}}$, which is the batch distribution coefficient, is defined as the equilibrium solid-phase ion concentration divided by the equilibrium liquid-phase concentration. It can be simplified to

$$
\mathrm{K}_{\mathrm{d}}=\left(\mathrm{C}_{\mathrm{i}}-\mathrm{C}_{\mathrm{f}}\right) / \mathrm{C}_{\mathrm{f}} * \mathrm{~V} / \mathrm{M} \text {, }
$$

where $\mathrm{C}_{\mathrm{i}}$ is the initial ion concentration in the feed solution; $\mathrm{C}_{\mathrm{f}}$ is the final concentration; $\mathrm{V}$ is the solution volume, in milliliters; and $\mathrm{M}$ is the exchanger mass, in grams. The simulated feed was $5 \mathrm{M}$ in Na, $0.12 \mathrm{M}$ in $\mathrm{K}, 5 \times 10^{-4} \mathrm{M}$ in $\mathrm{Cs}$, and $1.68 \mathrm{M}$ in free hydroxide concentrations.

Other batch tests were conducted to compare RF, SuperLig ${ }^{\circledR} 644$, and CST $(-38 B) .{ }^{5}$ In these tests, both double-shell tank slurry feed (DSSF) simulant composite and actual DSSF composite were compared in batch distribution tests, using $\mathrm{Na}$ concentrations of $0.2,1,3$, and $5 \mathrm{M}$ and $\mathrm{Na} / \mathrm{Cs}$ ratios of 50;500;5000; 50,000; and 500,000. Results were given for time-dependent $\mathrm{Cs}$ uptake for simulant at $5 \mathrm{MNa}$ and a Na/Cs ratio of 50,000 , indicating that up to $10 \mathrm{~h}$ was required for equilibrium to be reached for the RF, SuperLig ${ }^{\otimes}$ 644 , and CST. Equilibrium results for the RF showed a range of $\lambda\left(\mathrm{K}_{\mathrm{d}} \times\right.$ resin density) from 100 to 2000 , depending on the $\mathrm{Na}$ concentration at the same $\mathrm{Na} / \mathrm{Cs}$ ratio. Over the same range for SuperLig ${ }^{\circledR} 644$, the $\lambda$ also varied from 100 to 2000 , while the CST $-38 \mathrm{~B}$ ranged from 1000 to $>20,000$. When the exchanger results were compared with data for actual waste, the greatest deviations in performance were noted (1) for the $\mathrm{RF}$ resin, which had about 25 to $50 \%$ lower values across the range; and (2) for the CST - 38B at the highest $\mathrm{Na} / \mathrm{Cs}$ ratios, where the actual supernatant resulted in a $35 \%$ decrease in performance (although all exchangers showed decreased performance).

The predictions for operation of a column for the W-27 supernatant, based on the above batch tests, gave column volumes greater than those observed in the experiments. The batch distribution coefficients give an equilibrium measure of the overall ability of the solid-phase ion-exchange material to remove an ion 
from solution under the particular experimental conditions that exist during the contact. When simplified by using analyte concentrations in solution, the $K_{d}$ represents the theoretical volume of solution at equilibrium that can be processed per mass of exchanger, and multiplying by the bed density results in the theoretical number of bed volumes of solution that can be processed per volume of exchanger. ${ }^{4}$ For example, the $\operatorname{RF}(\rho=0.33$, where $\rho$ is the sorbent bulk dry density) batch results cited above suggest that $50 \%$ breakthrough should be achieved at approximately $100 \mathrm{CV}$; for SuperLig ${ }^{\circledR} 644 \mathrm{C}(\rho=0.33)$, it should occur at about $110 \mathrm{CV}$, and for CST $-38 \mathrm{~B}$ at about $800 \mathrm{CV}$. The results for the W-27 showed the actual CV to be $18-50$ for RF, $100-150 \mathrm{CV}$ for SuperLig ${ }^{\otimes} 644 \mathrm{C}, 17.5 \mathrm{CV}$ for CS-100, and $350 \mathrm{CV}$ for CST $-38 \mathrm{~B}(\rho=1.18)$. These results compare very favorably except for (1) the predictions for CST $-38 \mathrm{~B}$, which is affected by other ions present in the $\mathrm{W}-27$; and (2) the lower-than-expected $50 \%$ breakthroughs in most of the RF experiments, probably due to resin degradation during storage. The comparable experiments using the AEA RF resin did show $50 \%$ breakthrough predictions of greater than $100 \mathrm{CV}$ with the same W-27 used earlier, adding credence to the indication that degradation was the cause of the poor performance. The lower performance of the CSTs could be due to the higher $\mathrm{pH}$ level as well as the high concentration of nitrate in the W-27 supernatant.

\subsection{COMPARISON WITH RESULTS FROM OTHER CONTINUOUS COLUMN EXPERIMENTS}

SuperLig $^{\circledR} 644$ and RF ion-exchange materials were compared at PNNL in column tests using simulated alkaline supernatant solutions. ${ }^{8}$ The simulant in this series was $5 M$ in $\mathrm{Na}, 0.12 M$ in $\mathrm{K}, 5 \times$ $10^{-4} \mathrm{M}$ in $\mathrm{Cs}$, and $1.68 \mathrm{M}$ in free hydroxide. The tests used columns that were $2.54 \mathrm{~cm}$ in diameter, $41.9 \mathrm{~cm}$ tall, and contained $200 \mathrm{~mL}$ of ion-exchange resin. The flow rate through the columns was set at $9 \mathrm{CV} / \mathrm{h}$. The results for the SuperLig ${ }^{\otimes} 644$ showed almost immediate cesium breakthrough, as compared with the $\mathrm{RF}$ resin, and $50 \%$ breakthrough at about $100 \mathrm{CV}$, as compared with $140 \mathrm{CV}$ for the RF resin. SuperLig ${ }^{\circledR} 644$ used the low-density material and had a density about one-half that of the RF resin. The results for SuperLig ${ }^{\circledR} 644$ are comparable to those reported for the current series of W-27 tests. The RF results are almost seven times higher with the PNNL simulant than those achieved in these tests using the W-27 adjusted to $\mathrm{pH} 14$; this can be partly explained by the higher concentration of potassium in the W-27 supernatant and oxidation of the RF resin during storage. The elution of the RF and SuperLig ${ }^{\circledR} 644$ PNNL simulant-loaded resins showed the same patterns as reported here for W-27. The elution of 
SuperLig $^{\circledast}$ 644C from the W-27 loaded column yielded a very sharp peak using a comparatively small volume of eluent $(-6 \mathrm{CV})$, while the $\mathrm{RF}$ resin required a much larger volume of eluent to achieve the same eluent cesium concentration from the column (10-15 CV).

Additional considerations for the column studies include the effects of the resin or particle density on the performance during the column testing. If the resin is very light, the possibility exists that it may almost float and result in an unpacked column, thereby resembling a fluidized bed in its removal capabilities. Such effects can result in very early breakthrough of the cesium due to the dispersion through the bed. The columns used in this study had a bed depth/bed diameter ratio of about 4 ; thus, for the light organic resins, especially SuperLig ${ }^{\circledast 44 C}$, there was not very much material to create a long, packed depth. The compressibility of the SuperLig ${ }^{\circledR} 644 \mathrm{C}$ was noticed when the bed follower was used. The packed depth of the column decreased by about $30 \%$ when the follower was added in the presence of the $5 \mathrm{MNaNO}_{3}$. The compressibility was then taken into account, and the loading of the SuperLig ${ }^{\circledast} 644 \mathrm{C}$ discussed in the previous report ${ }^{1}$ was recalculated by using a column volume of $8.3 \mathrm{~cm}^{3}$ instead of $11.3 \mathrm{~cm}^{3}$ and plotted with the first loading of the multiple loading cycle discussed in Sect. 4.5. The results are shown in Fig. 19 for the original volume, the adjusted compressed volume, and the first loading of the multiple cycle. The original $50 \%$ breakthrough for the first case was $102 \mathrm{CV}$, while the calculated breakthrough based on the compressed volume was $138 \mathrm{CV}$. This compares more favorably with the $157 \mathrm{CV}$ obtained at $3.5 \mathrm{CV} / \mathrm{h}$ by using the W-27 adjusted to $\mathrm{pH} 14$. The flow rate for the test based on the compressed volume was $8 \mathrm{CV} / \mathrm{h}$ (instead of $6 \mathrm{CV} / \mathrm{h}$ ).

The PNNL studies ${ }^{5}$ used columns with a length/diameter ratio of $\sim 16$ and still had a very early breakthrough with the SuperLig ${ }^{\circledR} 644$. These results can be compared with the CST results obtained by using $-38 \mathrm{~B}$, where the initial breakthrough was at almost $100 \mathrm{CV}$. The CST is almost five times more dense than the SuperLig ${ }^{\circledR} 644 \mathrm{C}$ resin. Evidence for these density and bed-height effects was also seen with RF resin in several experiments and modeling efforts. ${ }^{17}$ In the case of the RF resin, results showed that a bed length/diameter ratio of 15 was required before the bed would actually behave like a fixed bed with a constant pattern. As a result, a weighted bed follower (described earlier) was successfully used for the RF and SuperLig ${ }^{\otimes}$ 644C loading and elution steps under $\mathrm{pH} 14$ conditions. Other possibilities for poor breakthrough curves are improper preconditioning of the bed and mismatching of bed presaturant and the column feed, both in salt concentration and in density. Some of these conditions could have had an effect 
ORNL DWG 97C-369

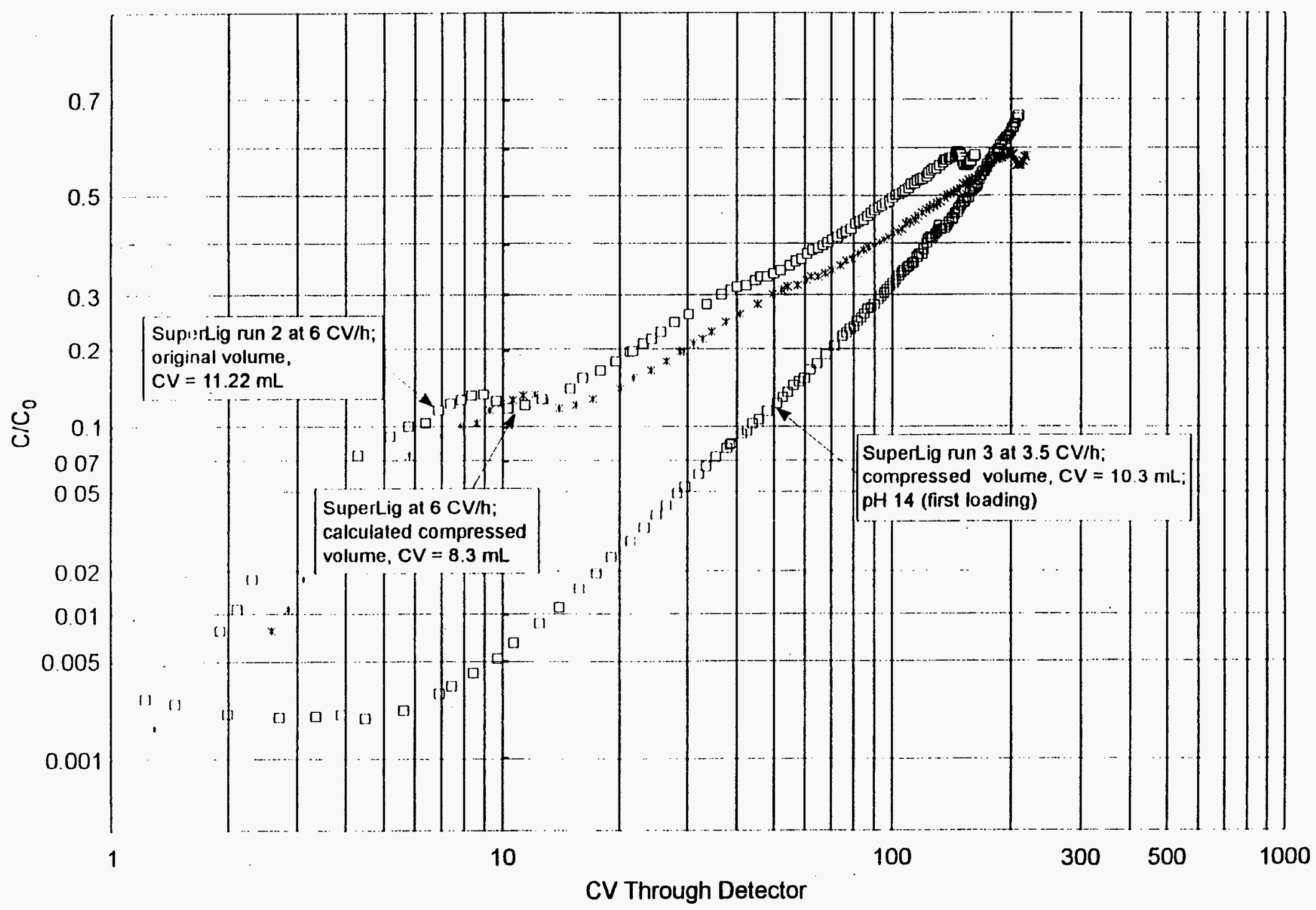

Fig. 19. Comparison of the recalculated results of the SuperLig ${ }^{\text {to }} 644 \mathrm{C}$ tests. 
on the runs with W-27 for the organic resins because, in some cases, they were washed with water before the W-27 feed ( $5 M$ salt) was introduced.

\subsection{PROBLEMS ASSOCIATED WITH THE RUNS}

Some of the experimental procedures generated solids in the effluent that collected in the equipment downstream from the column or module. In the RF and SuperLig ${ }^{\circledR} 644 \mathrm{C}$ runs, some reddish liquid left the column in the first part of the loading, elution, and preparation/regeneration steps. During one of the runs with SuperLig ${ }^{\oplus} 644 \mathrm{C}$, the first fraction collected during loading contained a brown liquid, but no solids; the last sample contained traces of solids, as did the lines to and from the fraction collector. No solids were observed in the collection bottles or tubes during the RF and SuperLig ${ }^{\circledR} 644 \mathrm{C}$ loading and elution experiments using the supernatant adjusted to $\mathrm{pH} \mathrm{14}$, although color was removed from the column and some colored material collected on the downstream filters. Preparation of the engineered forms of the CSTs (IONSIV IE-911 lots -0001 and -0003) required equilibration with caustic solution prior to use to prevent any aluminum precipitation due to the capacity of the CSTs to reduce the $\mathrm{pH}$ of the solution if not pretreated with caustic. The CSTs also had a tendency to produce fines upon changes of solution ionic strength. This problem was not encountered during operation, but it could cause difficulties during preparation and startup.

\section{CONCLUSIONS}

In order to compare all of the tested materials, the breakthrough curves under similar conditions were plotted together on the same graphs shown in Figs. 20 and 21. The results are also shown in Table 7. As can be readily seen, the CST materials exhibited better overall performance than any of the other materials when the column volumes to $50 \%$ breakthrough are compared at any flow rate, using the $\mathrm{W}-27$ feed at $\mathrm{pH}$ 12.95-13.32, or at $\mathrm{pH} 14$ with extra $\mathrm{Cs}$ added. The best kinetic performance occurred at $3 \mathrm{CV} / \mathrm{h}$. The CST was also able to maintain the column effluent at less than $1 \%$ breakthrough for much longer than the other materials except the RF (AEA batch) used in the last AEA test series. This means that the effluent through the CST columns contained lower levels of $\mathrm{Cs}$ (e.g., if $\mathrm{C} / \mathrm{C}_{0}$ is 0.01 , then $99 \%$ of the $\mathrm{Cs}$ is removed from the supernatant) as compared with the SuperLig ${ }^{\circledR}$ materials, which showed almost immediate 


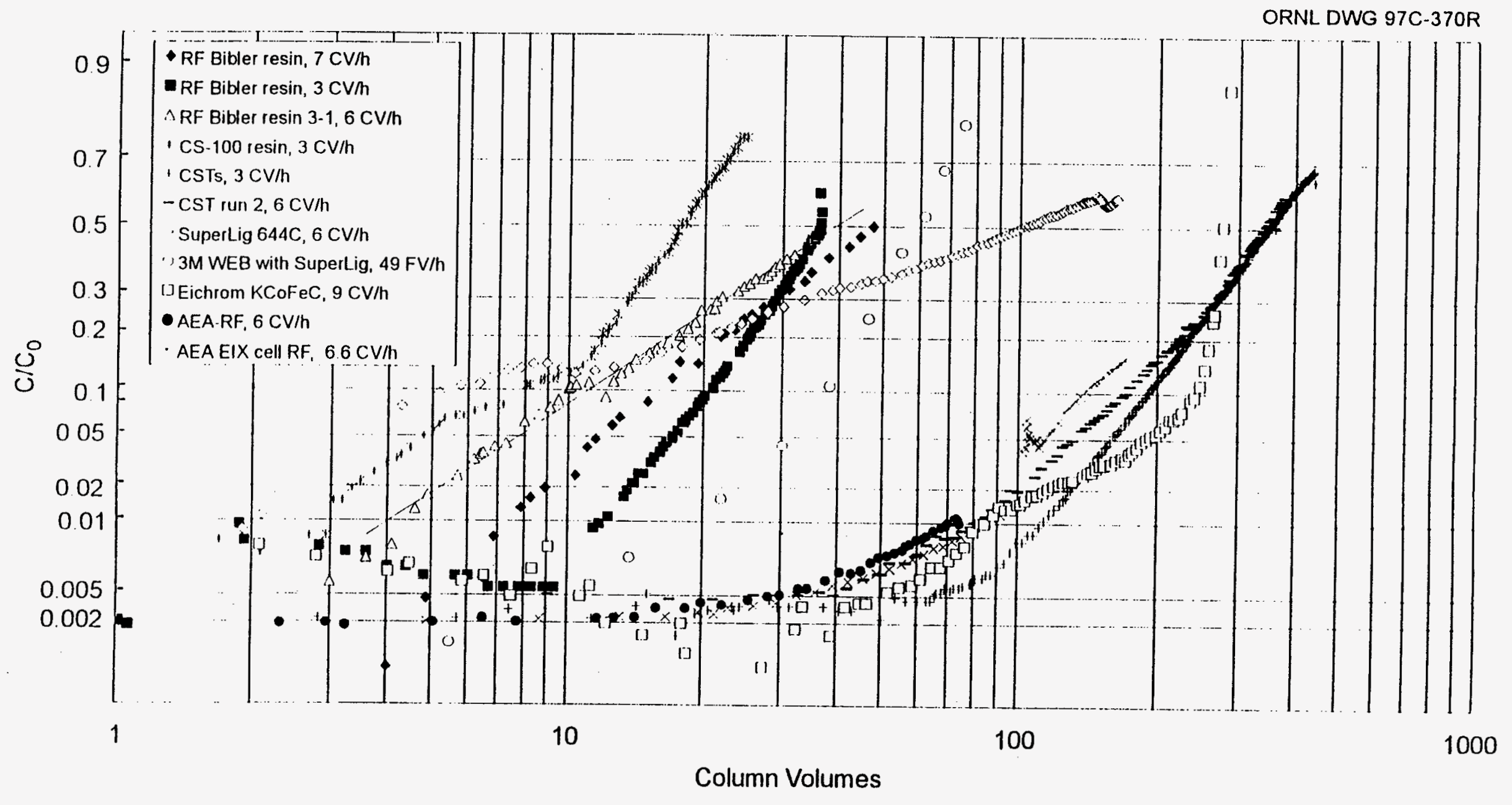

Fig. 20. Comparison of sorbents using MVST W-27 adjusted to pH 13.3. 
ORNL DWG 97C-371

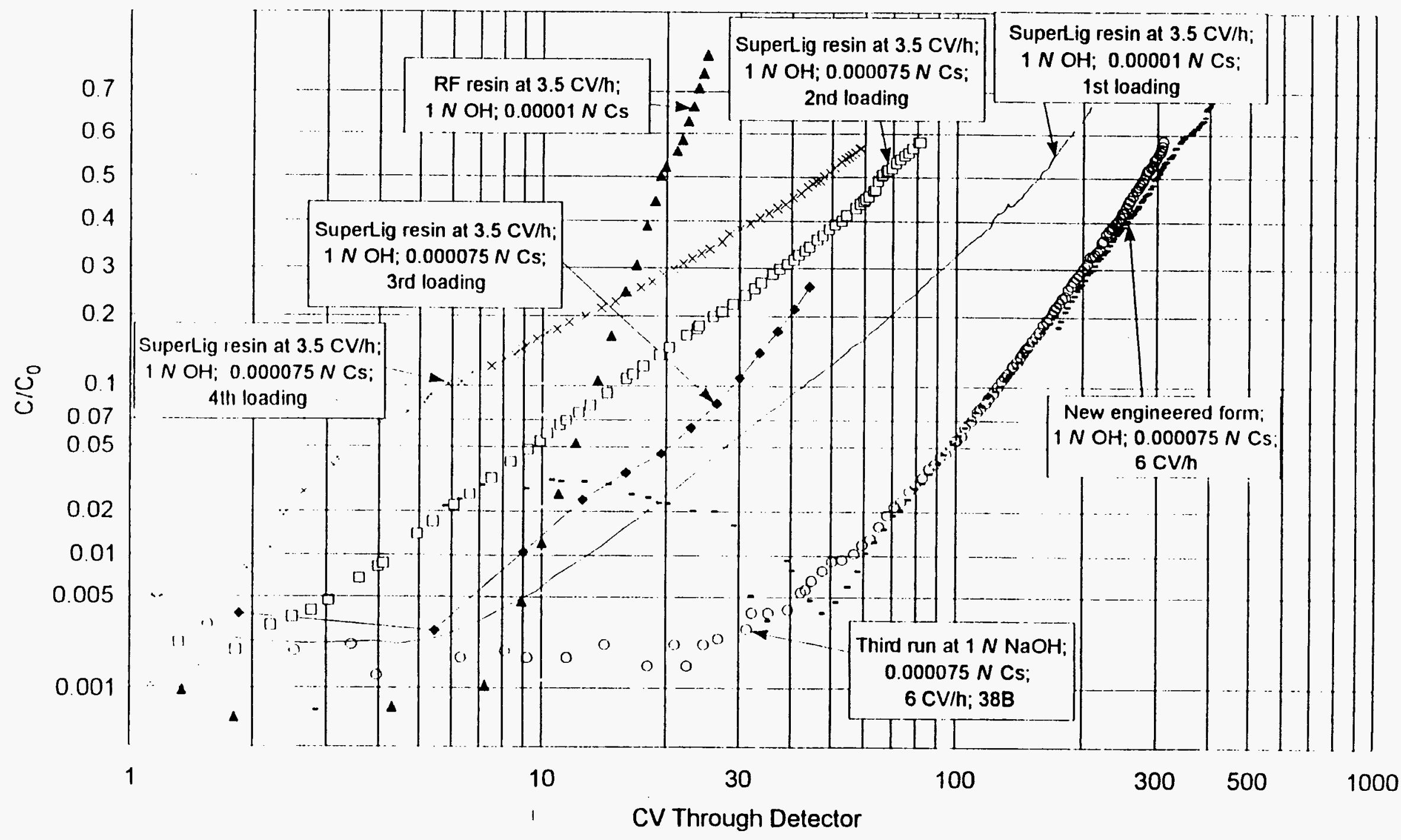

Fig. 21. Comparison of cesium sorbents using MVST W-27 adjusted to pH 14. 
Table 7. Comparison of the cesium sorbent experiments in Cell C, Building 4501 at ORNL

\begin{tabular}{|c|c|c|c|c|c|c|c|}
\hline Sorbent & $\begin{array}{c}\text { MVST W-27 } \\
\text { feed supernatant }\end{array}$ & $\begin{array}{c}\text { Flow rate } \\
(\mathrm{CV} / \mathrm{h})\end{array}$ & $\begin{array}{c}\text { Loading } \\
\text { cycles }\end{array}$ & $\frac{\mathrm{CVt}}{1 \%}$ & $\frac{\text { break }}{10 \%}$ & $50 \%$ & Comments \\
\hline CS-100 & $\mathrm{pH} 13.3 ; \mathrm{Cs}=7.5 \mathrm{E}-6 M$ & 3 & 1 & 3 & 7 & 18 & No longer commercial \\
\hline RF (Bibler-1995) & $\mathrm{pH} 13.3 ; \mathrm{Cs}=7.5 \mathrm{E}-6 \mathrm{M}$ & 3 & 1 & 12 & 20 & 35 & Color; shrink-swell \\
\hline RF (Bibler-1995) & $\mathrm{pH} 13.3 ; \mathrm{Cs}=7.5 \mathrm{E}-6 M$ & 6 & 5 & 4 & 11 & 40 & Color; operational \\
\hline RF (Bibler-1995) & $\mathrm{pH} 13.3 ; \mathrm{Cs}=7.5 \mathrm{E}-6 M$ & 7 & 1 & 7.5 & 17 & 48 & Color \\
\hline RF (REDC-Bibler) & $\mathrm{pH} 14.02 ; \mathrm{Cs}=1 \mathrm{E}-5 M$ & 6 & 1 & 10 & 14 & 18 & Color \\
\hline RF (AEA-BSC-187) & W-27; pH 13.3 & 6 & 1 & 65 & 140 & & Color; poor elution \\
\hline SuperLig $^{\circledR} 644 \mathrm{C}$ & W-27; pH 13.3 & 3 & 1 & 20 & 65 & & Color; low density, swell-shrink \\
\hline SuperLig $^{\circledR} 644 \mathrm{C}$ & W-27; pH 13.3 & 6 & 1 & 1 & 10 & 100 & Color; low density, swell-shrink \\
\hline SuperLig $^{\circledR} 644 \mathrm{C}$ & $\begin{array}{l}\mathrm{pH} 14.02 ; \mathrm{Cs}=1 \mathrm{E}-5 M ;(1) \\
7.5 \mathrm{E}-5 M(2-4)\end{array}$ & 3.5 & 4 & $\begin{array}{r}15 \\
4.5 \\
15 \\
2\end{array}$ & $\begin{array}{r}46 \\
16 \\
31 \\
6\end{array}$ & $\begin{array}{r}166 \\
70 \\
70 \\
50\end{array}$ & $\begin{array}{l}\text { Color; good elution; volume changes; } \\
\text { poor reproducibility }\end{array}$ \\
\hline 3M SLC WEB & W-27; pH 13.3 & 49.8 & 1 & 18 & 38 & 60 & Color; swell; poor elution \\
\hline $\mathrm{KCoFeC}$ & W-27; pH 13.3 & 9 & 1 & 85 & 250 & 250 & Disintegrates at $\mathrm{pH}$; fines produced \\
\hline CST-38B & W-27; pH 13.3 & 3 & 1 & 114 & 192 & 350 & No problems \\
\hline CST-38B & W-27; pH 13.3 & 6 & 1 & 82 & 174 & 342 & No problems \\
\hline CST-38B & $\begin{array}{l}\mathrm{pH} 14.02 ; \mathrm{Cs}=7.5 \mathrm{E}-5 \\
M\end{array}$ & 6 & 1 & 55 & 123 & 273 & No problems \\
\hline CST-0001 & $\mathrm{pH} 14.02 ; \mathrm{Cs}=7.5 \mathrm{E}-5 M$ & 6 & 1 & 60 & 129 & 296 & No problems \\
\hline CST-0003 & $\begin{array}{l}\mathrm{W}-29 ; \mathrm{pH} 12.6 ; \mathrm{Cs}= \\
4.4 \mathrm{E}-6 M\end{array}$ & 6 & 1 & 100 & 226 & 505 & No problems \\
\hline
\end{tabular}


breakthrough at more than $1-5 \%$ breakthrough in less than $10 \mathrm{CV}$. The last RF runs with the AEA RF resin, although not taken to $50 \%$ breakthrough, showed much improved capacity over the two batches of RF that had been previously tested, and the results were closer to those predicted, based on the earlier batch contacts.

Comparison of the column data for the W-27 feed with results obtained using simulant and actual supernatants at other sites (Figs. 9, 12, and 13) showed good agreement and predictability from batch equilibrium to column testing. There were exceptions, and the comparisons must take into account not only the cesium concentration, but also the hydroxide concentration, the other anions and cations in the supernatant, the ratios of the other cations to the cesium concentration, and, for the RF resin, the degree of degradation during storage.

The comparative evaluations discussed here have provided (1) critical data for the selection of the sorbent for the CsRD; (2) qualification of the sorbent chosen with the supernatant used; and (3) data applicable to other DOE sites, taking into account variations and differences in the supernatant compositions. In addition to the cesium removal capacity of the materials tested, the operational characteristics during continuous loading experiments were monitored. As described above, the organic sorbents RF and SuperLig ${ }^{\otimes}$ yielded colored products upon the first introduction of feed or during regeneration after elution. They also exhibited volume changes during various stages of the preparation, loading, elution, and regeneration steps.

\section{REFERENCES}

1. D. D. Lee, J. R. Travis, and M. R. Gibson, Hot Demonstration of Proposed Commercial Cesium Removal Technology, ORNL/TM-13169, Oak Ridge National Laboratory, Oak Ridge, Tenn., 1996.

2. E. A. Klavetter, N. E. Brown, D. E. Trudell, R. G. Anthony, D. Gu, and C. Thibaud-Erkey, "Ion-Exchange Performance of Crystalline Silicotitanates for Cesium Removal from Hanford Tank Waste Simulants," presented at Waste Management ‘94, Tucson, Ariz., 1994.

3. G. N. Brown, L. A. Bray, and R. J. Elovich, Evaluation and Comparison of SuperLig 644 , Resorcinol-Formaldehyde and CS-100 Ion Exchange Materials for the Removal of Cesium from Simulated Alkaline Supernatant, PNL-10486, Pacific Northwest National Laboratory, Richland, Wash., 1995.

4. R. G. Dosch, N. E. Brown, H. P. Stephens, and R. G. Anthony, "Treatment of Liquid Nuclear Wastes with Advanced Forms of Titanate Ion Exchangers," presented at Waste Management '93, Tucson, Ariz., 1993. 
5. S. F. Marsh, Z. V. Svitra, and S. M. Bowen, Distributions of 15 Elements on 58 Absorbers from Simulated Honford Double-Shell Slurry Feed (DSSF), LA-12863, Los Alamos National Laboratory, Los Alamos, N.M., 1994.

6. J. P. Bibler, Year-End Report for UST: Cesium Extraction Testing Project DOE/DT\&E TTP No. SRI-03-20-01 (U), WSRC-RP-94-146, Westinghouse Savannah River Company, Aiken, S.C., 1994.

7. J. L. Collins, B. Z. Egan, K. K. Anderson, C. W. Chase, and J. T. Bell, "Batch Test Equilibration Studies Examining the Removal of $\mathrm{Cs}$, Sr, and Tc from Supernatants from ORNL Underground Storage Tanks by Selected Ion Exchangers," in Challenges and Innovations in the Management of Hazardous Waste, Proceedings of the 2nd International Conference of Waste Management, May 10-12, 1995, Washington, D.C.

8. J. L. Collins, B. Z. Egan, K. K. Anderson, C. W. Chase, J. E. Mrochek, J. T. Bell, and G. E. Jernigan, Evaluation of Selected Ion Exchangers for the Removal of Cesium from MVST W-25 Supernatant, ORNL/TM-12938, Oak Ridge National Laboratory, Oak Ridge, Tenn., April 1995.

9. R. R. Brunson, D. F. Williams, W. D. Bond, D. E. Benker, F. R. Chattin, and E. D. Collins, Removal of Cesium from Aluminum Decladding Wastes Generated in Irradiated Target Processing Using a Fixed-Bed Column of Resorcinol-Formaldehyde Resin, ORNL/TM-12708, Oak Ridge National Laboratory, Oak Ridge, Tenn., September 1994.

10. A. G. Croff, ORIGEN2-A Revised and Updated Version of the Oak Ridge Isotope Generation and Depletion Code, ORNL-5621, Oak Ridge National Laboratory, Oak Ridge, Tenn., March 1986.

11. M. B. Sears, J. L. Botts, R. N. Ceo, J. J. Ferrada, W. H. Griest, J. M. Keller, and R. L. Schenley, Sampling and Analysis of Radioactive Liquid Wastes and Sludges in Melton Valley and Evaporator Facility Storage Tanks at ORNL, ORNL/TM-11652, Oak Ridge National Laboratory, Oak Ridge, Tenn., September 1990.

12. G. N. Brown, J. R. Bontha, C. D. Carlson, J. R. DesChane, R. J. Elovich, D. E. Kurath, P. K. Tanaka, D. W. Edmonson, D. L. Herting, and J. R. Smith, Ion Exchange Removal of Cesium from Simulated and Actual Supernatant from Hanford Tanks 241-SY-101 and 241-SY-103, PNL-10792, Pacific Northwest National Laboratory, Richland, Wash., September 1995.

13. G. N. Brown, L. A. Bray, C. D. Carlson, K. J. Carson, J. R. DesChane, R. J. Elovich, F. V. Hoopes, D. E. Kurath, L. L. Nenninger, and P. K. Tanaka, Comparison of Organic and Inorganic Ion 
Exchangers for Removal of Cesium and Strontium from Simulated and Actual Hanford 241-AW-101 DSSF Tank Waste, PNL-10920, Pacific Northwest National Laboratory, Richland, Wash., January 1996.

14. T. E. Kent, Oak Ridge National Laboratory, personal communication, May 1996.

15. V. L. Fowler, Oak Ridge National Laboratory, personal communication, January 1995.

16. D. W. Hendrickson, R. K. Biyani, and M. A. Beck, Hanford Tank Waste Supernatant Cesium Removal Test Report, WHC-SD-RE-TRP-018, Rev. OA, Westinghouse Hanford Company, Richland, Wash., October 1996.

17. N.-H. Linda Wang, Purdue University, personal communication, Feb. 6, 1996. 
ORNL/TM-13363

\section{INTERNAL DISTRIBUTION}
1. J. B. Berry
2. J. L. Collins
3. A. G. Croff
4-8. M. R. Gibson
9. R. D. Hunt
10. R. T. Jubin
11. T. E. Kent
12-16. D. D. Lee
17. A. P. Malinauskas
18. C. P. McGinnis

\author{
19. L. E. McNeese \\ 20. B. A. Moyer \\ 21. S. M. Robinson \\ 22. M. G. Stewart \\ 23-27. J. R. Travis \\ 28. J. F. Walker, Jr. \\ 29. J. S. Watson \\ 30. Central Research Library \\ 31. ORNL Laboratory Records-RC \\ 32-33. ORNL Laboratory Records-OSTI
}

\section{EXTERNAL DISTRIBUTION}

34. G. Allen, Department 6607/MS 0756, Sandia National Laboratories, P.O. Box 5800, Albuquerque, NM 87185-0756

35. Dr. R. G. Anthony, Department of Chemical Engineering, Texas A\&M University, College Station, TX 77843

36. J. E. Baublitz, EM-40, DOE/Office of Environmental Restoration, Forrestal Building, U.S. Department of Energy, 1000 Independence Ave. SW, Washington, DC 20585

37-38. W. W. Bixby, EM-60, DOE/Office of the Deputy Assistant Secretary Facility, Transition and Management, U.S. Department of Energy, 1000 Independence Ave. SW, Washington, DC 20585

39. N. E. Brown, 6608 Loftus, NE, Albuquerque, NM 87109

40. R. L. Bruening, IBC Advanced Technologies, Inc., 505 East 1860 South, American Fork, UT 84603

41. J. Corones, Ames Laboratory, 329 Wilhelm Hall, Iowa State University, Ames, IA 50011

42. R. Craig, HAZWRAP, P.O. Box 2003, MS-7606, Oak Ridge, TN 37831-7606 
43-48. DOE/Office of Science and Technology, Trevion II Building, 12800 Middlebrook Road, Germantown, MD 20874, ATTN: G. G. Boyd, EM-50; S. T. Lien, EM-53; R. T. Parker, EM-52; P. J. Ritzcovan, EM-542; W. C. Schutte, EM-54; and S. M. Wolfe, EM-532

49-50. West Valley Nuclear Services, P.O. Box 191, West Valley, NY 14171-0191, ATTN: Ted T. Borek, WV-MP3 and W. J. Connors, WV-MP3

51-55. DOE/Office of Waste Management, Trevion II Building, 12800 Middlebrook Road, Germantown, MD 20874, ATTN: J. O. Boda, EM-32; J. A. Coleman, EM-35; S. P. Cowan, EM-30; S. L. Domotor, EM-35; and H. F. Walter, EM-34

56. B. Erdal, Los Alamos National Laboratory, MS D446, Los Alamos, NM 87545

57. D. J. Fennelly, UOP Corp., 307 Fellowship Road, Suite 207, Mt. Laurel, NJ 08054

58-59. J. J. Fiore, EM-42, DOE/Office of Environmental Restoration, Trevion II Building, 12800 Middlebrook Road, Germantown, MD 20874

60. C. W. Frank, EM-50, DOE/Office of Technology Development, Forrestal Building, U.S. Department of Energy, 1000 Independence Ave. SW, Washington, DC 20585

61. Dave Geiser, EM-53, Office of Technology Systems, U.S. Department of Energy, Headquarters, 19901 Germantown Road, Germantown, MD 20874-1290

62. K. D. Gerdes, EM-532, DOE/Office of Technology Development, 19901 Germantown Road, Germantown, MD 20874

63. J. E. Helt, Office of Waste Management Programs, 9700 South Cass Avenue, Argonne, IL 60439-4837

64-66. T. M. Kafka, 3M Center, Bldg. 209-1W-24, St. Paul, MN 55144-1000

67. K. Kostelnik, EG\&G Idaho, Inc., MS 3930, P.O. Box 1625, 200 South Woodruff, Idaho Falls, ID 83415-3970

68. J. E. Lytle, EM-30, DOE/Office of Waste Operations, Forrestal Building, U.S. Department of Energy, 1000 Independence Ave. SW, Washington, DC 20585

69. J. F. McGlynn, SAIC, 555 Quince Orchard Road, Suite 500, Gaithersburg, MD 20878

70. Rebecca L. Miller, Los Alamos National Laboratory, CST-11, MS J517, Los Alamos, NM 87545

71. J. Moore, U.S. Department of Energy, Oak Ridge Operations Office, P.O. Box E, Oak Ridge, TN 37831 
72-74. Sandia National Laboratories, P.O. Box 5800, Albuquerque, NM 87185-5800, ATTN: G. Allen, MS-0756; J. E. Miller, MS-0709; and J. Nelson, MS-6621

75. Wally Schulz, 5314 Arbustos Court, NE, Albuquerque, NM 87111

76. J. L. Steele, Savannah River Site, SRL, 773 A, A208, Aiken, SC 29802

77. S. L. Stein, Battelle Seattle Research Center, 4000 NE 41st Street, Seattle, WA 98105

78. J. L. Swanson, 1318 Cottonwood Drive, Richland, WA 99352

79. J. Sweeney, U.S. Department of Energy, Oak Ridge Operations Office, P.O. Box E, Oak Ridge, TN 37831

80. I. R. Tasker, Waste Policy Institute, Quince Diamond Executive Center, 555 Quince Orchard Road, Gaithersburg, MD 20878-1437

81-83. Savannah River Technology Center, P.O. Box 616, Savannah River Technical Center, Aiken, SC 29808, ATTN: M. C. Thompson, D. McCabe, and J. Plodinec

84-85. T. A. Todd, Lockheed Idaho Technology Company, P.O. Box 1625, MS 5213, Idaho Falls, ID 83415

86. S. Turner, BNFL, 2261 Stevens Drive, Richland, WA 99352

87-88. UOP Corporation, 50 East Algonquin, Des Plaines, $\mathbb{I}$ 60017-5016, ATTN: J. Sherman and R. Braun

89. S. Webster, U.S. Department of Energy, Chicago Field Office, 9800 South Cass Avenue, Argonne, IL 60439-4837

90. T. Williams, U.S. Department of Energy, Idaho Operations Office, 785 DOE Place, Idaho Falls, ID 83402

91. J. Wright, U.S. Department of Energy, Savannah River Operations Office, RFD \#1, Bldg. 703A, Rm. E208 North, P.O. Box A, Aiken, SC 29802

92-95. U.S. Department of Energy, Richland Operations Office, 825 Jadwin Avenue, Richland, WA 99352, ATTN: J. A. Frey, K8-50; C. S. Louie, S7-53; B. M. Mauss, K8-50; and D. E. Trader, K8-50

96. D. J. Swanberg, MACTEC, K8-50, Richland, WA 99352

97-101. SGNEURISYS Services Corporation, P.O. Box 840, Richland, WA 99352-0840, ATTN: M. D. Britton, S4-25; K. M. Eager, H5-27; D. Hendrickson; M. J. Klem, H5-27; and D. L. Penwell, H5-27 
102-109. Pacific Northwest National Laboratory, Battelle Boulevard, P.O. Box 999, Richland, WA 99352, ATTN: L. A. Bray, P7-25; K. P. Brooks, P7-43; G. N. Brown, P7-25; T. L. Hubler, P8-38; W. L. Kuhn, K2-21; D. E. Kurath, P7-20; J. P. LaFemina, K2-25; and J. T. Slankas, K9-81

110. Moses Attrep, Los Alamos National Laboratory, P.O. Box 1663, MS J514, Los Alamos, NM 87544

111. Jerry Harness, U.S. Department of Energy, Oak Ridge Operations Office, P.O. Box E, Oak Ridge, TN 37831

112. Lisette Nenninger, SAIC, 555 Quince Orchard Road, Gaithersburg, MD 20878

113. Ray Wymer, 188-A Outer Drive, Oak Ridge, TN 37830

114-117. Lockheed Martin Hanford Corporation, P.O. Box 1970, Richland, WA, 99352, ATTN: J. N. Appel, G3-21; S. A. Barker, R2-11; W. B. Barton, R2-11; and K. A. Gasper, G3-21 
M98054255

||||||||||||||||||||||||||||||||||||

Report Number (14)ORNL/TM-. $/ 3363$

Publ. Date (11) $1997 / 2$
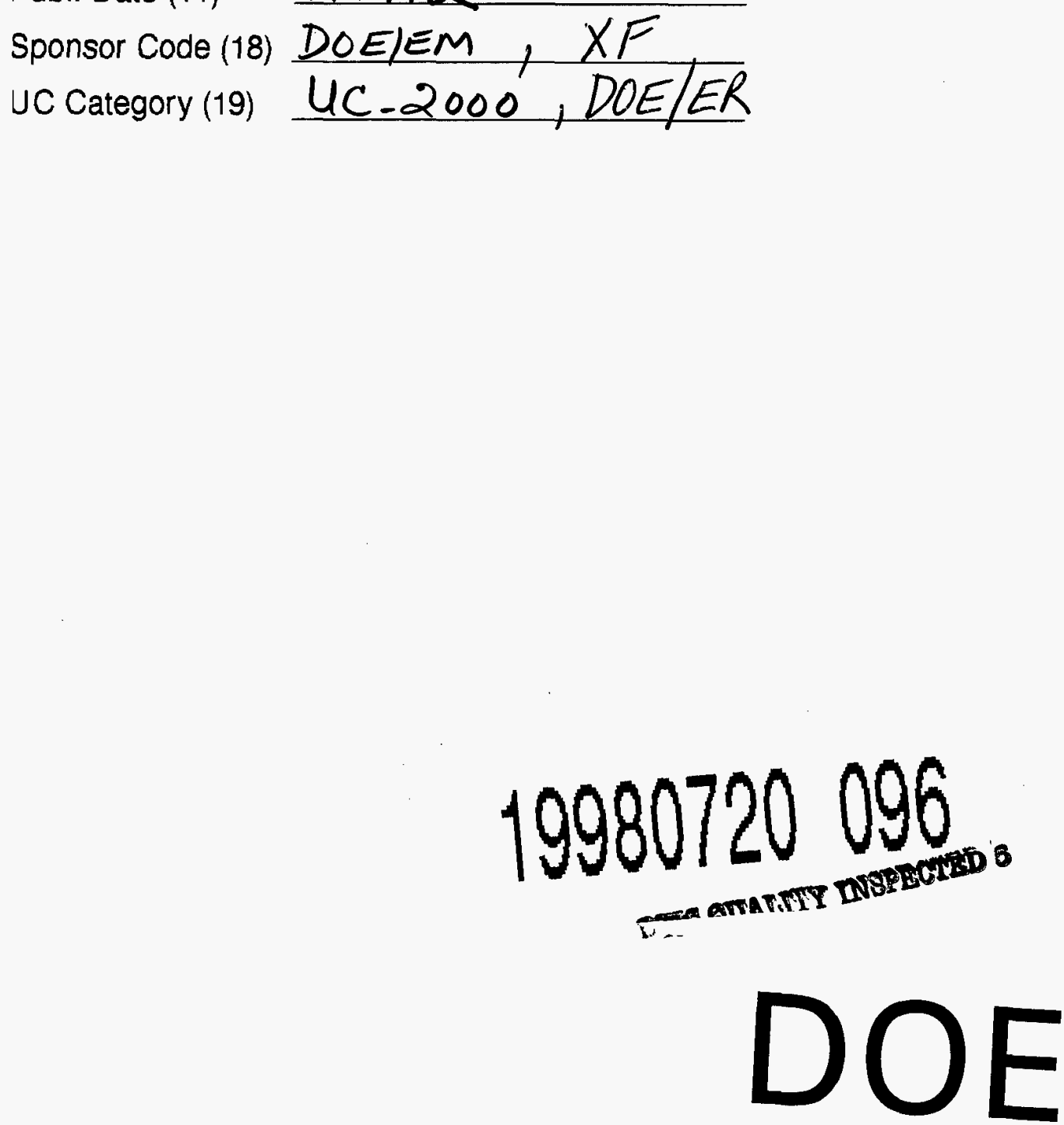